\title{
Technology paradigm shifts in agriculture: drivers of sustainability and catch up
}

Citation for published version (APA):

Thutupalli, V. S. A. (2015). Technology paradigm shifts in agriculture: drivers of sustainability and catch up. [Doctoral Thesis, Maastricht University]. Datawyse / Universitaire Pers Maastricht. https://doi.org/10.26481/dis.20151104vt

Document status and date:

Published: 01/01/2015

DOI:

$10.26481 /$ dis.20151104vt

Document Version:

Publisher's PDF, also known as Version of record

\section{Please check the document version of this publication:}

- A submitted manuscript is the version of the article upon submission and before peer-review. There can be important differences between the submitted version and the official published version of record.

People interested in the research are advised to contact the author for the final version of the publication, or visit the DOI to the publisher's website.

- The final author version and the galley proof are versions of the publication after peer review.

- The final published version features the final layout of the paper including the volume, issue and page numbers.

Link to publication

\footnotetext{
General rights rights.

- You may freely distribute the URL identifying the publication in the public portal. please follow below link for the End User Agreement:

www.umlib.nl/taverne-license

Take down policy

If you believe that this document breaches copyright please contact us at:

repository@maastrichtuniversity.nl

providing details and we will investigate your claim.
}

Copyright and moral rights for the publications made accessible in the public portal are retained by the authors and/or other copyright owners and it is a condition of accessing publications that users recognise and abide by the legal requirements associated with these

- Users may download and print one copy of any publication from the public portal for the purpose of private study or research.

- You may not further distribute the material or use it for any profit-making activity or commercial gain

If the publication is distributed under the terms of Article $25 \mathrm{fa}$ of the Dutch Copyright Act, indicated by the "Taverne" license above, 


\section{Technology paradigm shifts in Agriculture}

Drivers of Sustainability and Catch up

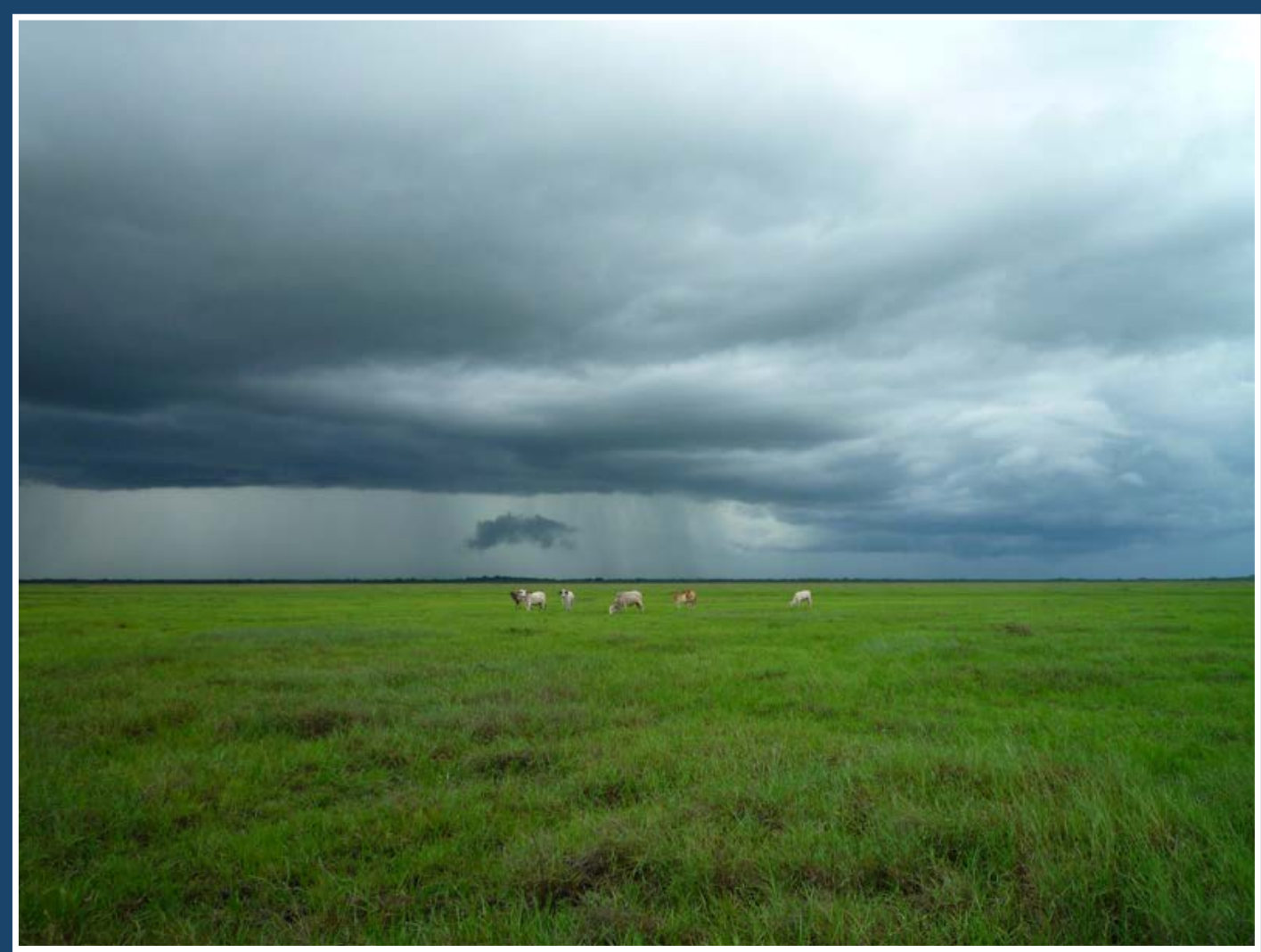

Ajay Thutupalli 
(c) Copyright A. Thutupalli

Print: Datawyse | Universitaire Pers Maastricht ISBN: 9789461594921 


\title{
Technology Paradigm Shifts in Agriculture: Drivers of Sustainability and Catch up
}

\author{
DISSERTATION \\ to obtain the degree of Doctor at \\ Maastricht University, \\ on the authority of the Rector Magnificus Prof. dr. L. L. G. Soete, \\ in accordance with the decision of the Board of Deans, \\ to be defended in public on Wednesday 04 November 2015, at 14:00 hours
}

by

Venkatasubbu Sai Ajay Thutupalli

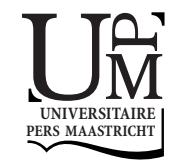




\section{Supervisor}

Prof. Dr. Shyama V. Ramani

\section{Assessment Committee}

Prof. Dr. Bart Verspagen (Chair)

Prof. Dr. Adam Szirmai

Prof. Dr. Pakki Reddy Giddaluri (Agribiotech Foundation, India)

Dr. Nyasha Tirivayi 


\section{Acknowledgements}

It is with great pleasure that I thank Prof. Shyama V Ramani for mentoring and bearing with me throughout my PhD journey. I thank the members of the thesis committee Prof. Bart Verspagen, Prof. Adam Szirmai, Prof. Pakki Reddy Giddaluri, and Dr. Nyasha Tirivayi for agreeing to read my thesis and provide valuable feedback. Further my thesis has benefitted from the comments and suggestions of participants of conferences which include Globelics (2013 \& 2014), AIE (2013), UNUMERIT 25 years (2014) and EMAEE (2015).

I have benefitted a great deal from the support of Eveline, Marc, Wilma, Herman, Ad, Howard and Eric during my PhD journey. I have been lucky to have made good friends and colleagues in UNU-MERIT. I would like to thank Hibret, Eduardo and Michael for the many enriching conversations that helped me understand how economists should think. Iman, Shuan, Jeniffer, Francesca, Francois, Alejandro, Daniel, Samyukta, Sachin, Sutapa, Michiko, Marco, Jojo, Dorcus, Giorgio, Hassen, Yesuf, Tigist, Omar, Tatevik, Andrea, Biljana, Charlotte, Mira, George, Stefania, Jamaal, Bruhan, Wondi, Eleni all made UNU-MERIT a pleasant place.

Having had systems engineering background, dwelling into the unchartered waters of economic analysis of crop production technologies is quite a journey. This journey is made possible by the support of several individuals in Europe and India. I am indebted to Prof. Pakki Reddy Giddaluri for offering all the necessary institutional support and mentoring, whom I met by chance in a farmer outreach programme in my home town. I would like to thank K L Prasanna Kumar for all the help rendered to me during and beyond my stay at Agri Biotech Foundation (ABF). Mrs. Padmaja, Dr. P. Sreeramulu, Dr. J S Bentur, Seenu, Ramidha, Naresh, Teja and Nagaraju provided me with the necessary academic and non-academic support while at $\mathrm{ABF}$.

I would like to thank Sunil Kumar Nakka for the countless discussions we had on the Indian and multinational seed firms from the view point of sales and marketing and his pointers for valuable information sources within the sector. I thank my cousin P C Krishna Mohan for sharing with me his years of first-hand experience in farming and insights on contemporary technology adoption and implementation practices of farmers. My friend Ravi Gettiboyina and his father Pedda Rosaiah Gettiboyina got me into direct contact with farmers of Atmakur and Udayagiri who offered me valuable insights on rain fed cotton farming. I thank them for the same.

I would like to thank all the public and private sector scientists, economists and other Indian seed sector stake-holders who have agreed to participate in my inter- 
views to share their knowledge, experiences and perspectives on genetically modified crops.

I would like to thank all the enthusiastic farmers of Andhra Pradesh for readily agreeing to participate in the survey, for inviting me for a chai to their houses or at times allowing me to sit amidst a village gathering under a peeple or banyan tree where all sorts of important and more often than not casual discussions take place. They were kind enough to discuss and debate among themselves their experiences and perspectives not only on Bt cotton but a range of historical and contemporary issues related to farming thereby offering me invaluable knowledge and ideas.

Finally I would like to thank my family members - Sireesha, Aniketh, Aarsha, my parents, my sister Avanthi, my in-laws, members of extended family for the many encouraging moments that kept me going.

I am grateful for the financial support of UNU-MERIT which allowed me to carry out this research. 


\section{Summary (Nederlands)}

Terwijl radicale technologische doorbraken de basis leggen voor een belangrijke verschuiving in de bestaande technologische domeinen, leiden zulke verschuivingen tot een scala van sociaaleconomische en ecologische onzekerheden. Deze onzekerheden creëren waarschijnlijk een aantal beleidsproblemen om duurzaamheid te garanderen. Tegelijkertijd kunnen ingrijpende veranderingen in het technologisch denkpatroon significante veranderingen veroorzaken in het innovatiesysteem, waardoor nieuwe strategische problemen of mogelijkheden voor andere actoren zoals boeren, lokale bedrijven, multinationals en publieke laboratoria worden gegenereerd. In deze context onderzoekt dit proefschrift de drijvers van duurzaamheid en de technologische inhaalslag in het kader van de veranderingen in het technologisch denkpatroon in de landbouw.

De voorgestelde theoretische constructie integreert zowel de evolutionaire reacties van de ecologie die streeft naar biofysische efficiëntie als het evolutionaire gedrag van de economische actoren die proberen economische efficiëntie te bereiken. Het empirisch bewijsmateriaal over GR-en GM-katoentransities in India suggereert dat de economische en ecologische resultaten die veranderingen in het technologisch denkpatroon typeren, divers kunnen zijn. Terwijl de GR-transitie wordt gekenmerkt door onzekere milieuresultaten, werpt Bt-katoen in India vragen op bij zowel de sociaal-economische als de milieuproblematiek. Op het sociaaleconomisch front heeft de Bt-katoenanalyse geen enkel evidente onzekerheid onthuld, terwijl op ecologisch gebied onzekerheid wordt onthuld in de vorm van evolutionaire veranderingen bij katoen-ongedierte.

De aanzetpunten van controverses kunnen in elke fase van een technologieovergang naar boven komen. In het bijzonder met betrekking tot de plantaardige productietechnologieën zijn waarschijnlijk de ecologische resultaten eerder dan de economische resultaten grotere aandachtspunten van controverse. Hoge directe afrekeningen kunnen zorgen die zijn gebaseerd op wetenschappelijke onzekerheid over de invoering van nieuwe technologieën teniet doen. Controverses zullen waarschijnlijk toenemen naarmate het innovatiesysteem complexer wordt.

Bij onderzoek onder boeren bleek een nauwe betrokkenheid tussen de beschikbare hulpbronnen en de voorkeuren van de boer richting technologie-keuze en de uitvoering ervan in het geval van genetisch gemodificeerd katoen. Terwijl het beeld van de invloed van Bt-katoen adopters heterogeen was, waren kleine boeren die geen toegang tot irrigatie hebben ecologisch bewust, en waren ze meer inschikkelijk om de naleving te volgen dan hun collega's met grote geïrrigeerde boerderijen. 
De analyse van het strategisch gedrag van de lokale zaadbedrijven in India ten opzichte van nieuwe agro-biotechnologie liet zien dat lokale bedrijven die zich bezighouden met agro-biotechnisch R\&D kunnen kiezen uit diverse strategieën op basis van hun sterke punten in globale en in situ kenniscomponenten. De onderliggende technologie en de verschillen in kennismogelijkheden presenteren diverse trajecten op het gebied van technologische inhaalslag.

De strategie van een multinational, Monsanto, in het lokaliseren van de radicale innovatie, Bt-katoen in India suggereert dat multinationale ondernemingen moeten werken aan het legitimeren van hun radicale innovatie middels strategische hulpverlening aan meerdere stakeholders in de opkomende landen. Bedrijven kunnen kiezen uit passieve co-existentie, marktinteractie, samenwerking, confrontatie en compromissenstrategieën. 


\section{Chapter Index}

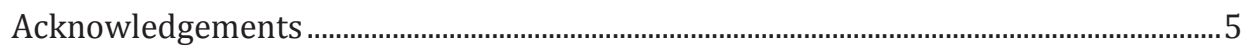

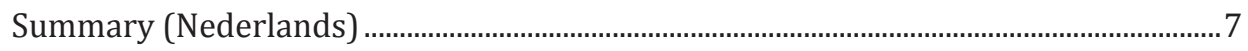

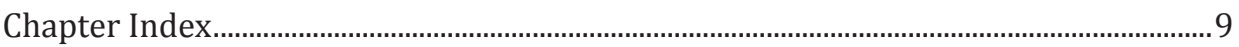

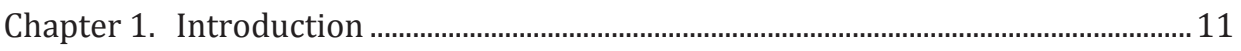

Chapter 2. Towards a theoretical framework of technology paradigm shift............ 21

Chapter 3. Economic and ecological outcomes of GR and GM paradigms: A systematic review.

Chapter 4. Emergence of controversy in technology transitions 57

Chapter 5. Technology transitions and sustainable adoption, a farmer's perspective. 73

Chapter 6. Technology transitions and catching up of local firms 95

Chapter 7. Localization of radical innovations, a multinational's perspective .... 121

Chapter 8. Concluding Remarks. 135

Societal Relevance. 143

Bibliography . 145 



\section{Chapter 1. Introduction}

\subsection{Setting the background}

The cultivation of plant crops forms a part of the agricultural production, which in turn makes an important contribution to the national income and employment of most developing countries. For instance, even as recently as in 2014, large proportions of populations, about 66\% in South Asia and about 59\% in Africa lived in rural areas dependent on the agriculture sector directly or indirectly for their livelihoods (UNFAO, 2015b). While the global commodity booms and bursts are a major source of uncertainty for the future of this sub-sector (i.e. crops) on the demand side, increasingly erratic climatic conditions such as rising temperatures, droughts and problems of resource degradation are posing threats to the livelihoods of farmer-producers on the supply side. Thus, maintaining agricultural productivity and sustaining farmers livelihoods are important challenges in many countries especially those of South Asia and Africa.

Sustainable agriculture is defined as that which is economically profitable for farmers, environmentally friendly and socially benefiting (Hansen, 1996; GómezLimón and Sanchez-Fernandez, 2010). Any agricultural technology or practice that contributes to the above mentioned characteristics of sustainable agriculture can be considered as a sustainable technology. Sustainability in agriculture therefore is determined by not only the socio-economic outcomes but also by the ecological outcomes of the production processes.

Coming to augmenting crop production, expanding the land under cultivation is a difficult task and irrigation can be extended and intensified only to a limited level. Therefore, it is necessary to explore ways in which yields can be increased by more efficient input technologies. Agricultural production involves two components, tangible inputs and application practices of the inputs. Examples of the former include seed, fertilizers, pesticides etc. while the quantity and manner in which fertilizers are applied exemplify the latter. By technical change we mean changes to either of these components. Productivity increase in crop production (henceforth referred to as agriculture) emerges from technical change that can either save on labour efforts or push up the yields. While farm equipment such as mechanical ploughs, tractors, and sprayers decrease labour input, quality seeds and fertilizers increase yields. Over the past five decades (1960-2011) in developing countries such as India, Indonesia and countries of Sub-Saharan Africa growth in crop production has been mainly driven by expansion of cultivated land, increased labour, increased use of agrochemicals and better quality seeds (USDA, 2015). The last input, namely seeds, which have a one to one correspondence with new plant varieties, is the focus of this thesis. 
During the 1960's global crop production was marked by the entry of a revolutionary technology commonly referred to as Green Revolution (henceforth GR). The GR as a technology package included improved quality seeds, to be planted along with controlled irrigation and measured doses of fertilizers. While the GR technologies heralded a veritable increase in yields across several nations, it left in its wake environmental concerns in countries like India such as soil degradation, ground water depletion and contamination. Today, the 'Green' Revolution itself is felt to be 'yellowing' and in its place, rejuvenation of the agriculture sector is being promised by modern biotechnology. Modern biotechnology refers to processes that manipulate or change the genetic patrimony of cells of micro-organisms, plants or animals. The development of solutions based on modern biotechnology involves application of tools and techniques such as genetic engineering, molecular markers, and micro propagation. The plants whose genetic makeup is modified using modern biotechnology techniques are called Genetically Modified (henceforth GM) plants or transgenic plants. Typical challenges addressed via modern biotechnology include making plants more resistant to pests, more resistant to diseases and challenging ecological conditions.

While GM plants raise hopes in terms of their technological potential, they have also provoked societal resistance in many parts of the world. This is because of the real uncertainty concerning the long term impact of GM plant varieties on environment and health. Indeed, this is fueling the science and technology, and agricultural policy debates among nations. For instance, the difference of opinion on GM crops is starkly evident with European Union countries opposing the planting of GM crops while the United States and other emerging countries such as China and Brazil have adopted them. Nevertheless, while there is an ongoing controversy on whether or not developing transgenic crops is the right approach, growing demand for food and persistent productivity problems are making developing countries pay serious attention to GM seed technology. In sum, the present day sustainability debates in agriculture are centered on the long term economic, health and environmental impacts of genetically modified crops.

As later chapters of this dissertation will detail, while GR technologies were developed and diffused by few international and national public sector labs, the agribiotechnology is a totally a private sector ball game. In contrast to GR, GM crops and their underlying technology are majorly commercialized by multinationals (henceforth MNEs). Today, MNEs have a huge presence in the global agricultural input markets which includes markets for seeds, pesticides and technologies. In 2011 , top ten private firms controlled $75 \%$ of the global seed market shares and $94 \%$ of pesticides and fertilizer market shares. In fact, three firms, Monsanto, DuPont and Syngenta owned more than $53 \%$ of the global seed market shares. Between 2004 and 2008, three firms accounted for $72 \%$ of utility patent applica- 
tions in plant varieties, and $44 \%$ of applications for plant variety protection certification (ETC-Group, 2013a; ETC-Group, 2013b). These figures indicate the leadership of MNEs both in terms of the knowledge base and market performance of both conventional and genetically modified plant varieties.

The first commercial GM crop, the 'FlavrSavr tomato' with a delayed ripening trait was approved in 1994 in the USA, by a firm called Calgene, which was later on acquired by Monsanto. Thereafter, several crops including soybean, maize, canola and cotton with desired traits such as disease resistance, insect resistance and herbicide tolerance were developed and commercialized by leading firms such as Monsanto and Syngenta. Among the emerging countries GM crops were first introduced in China and Mexico in 1996, either directly by the MNEs or by local firms via licenses accorded to them by the MNEs. Subsequently GM crops were introduced into Brazil, India, Indonesia, South Africa, Burkina Faso, Sudan, Cuba and Egypt among the developing countries. As of 2013, 27 GM crop varieties are commercially approved for either planting or import across 27 countries being planted over 175.2 million hectares of land, with developing countries leading the acreage(James, 2013).

The introduction of GM technology engendered another new phenomenon, namely that of inter-firm cooperation between MNEs and local firms. The new GM plant varieties developed by MNEs are not robust vis-à-vis the local conditions of emerging countries. In other words, when a GM plant variety developed by an MNE in its home country is replanted in another country, it is not likely to survive given the different agro-ecological conditions. Thus, the value added of the underlying technology can be demonstrated only when the GM plant developed by the MNE is incorporated into the varieties that are locally robust. These are usually the plant varieties developed by local firms.

At a macro-level, while there is a very significant gap in the technological and innovative capabilities of MNEs and local firms, the latter's relative strength vis-a-vis MNEs lies in their proprietorship of robust plant varieties suitable for local conditions and their knowledge of local consumer preferences, willingness to pay, customer base and marketing networks. Such complementary competencies necessitate co-operation between MNEs and local actors through R\&D collaboration or market transactions such as technology licensing, marketing and distribution agreements. In turn such collaboration provides avenues for local firms to catch up.The term 'catch up' refers to closing the gap in technological capabilities, leading to increased economic performance by follower actors vis-a-via a leader, both of which can be a firm, industry or a country. 
To sum up, the twin challenges of developing country agriculture are ensuring sustainability and catch up in crop production technologies. However these two conditions do not necessarily go in the same direction i.e, technological catch up could also be achieved in an ecologically unsustainable manner. Therefore social planners should target technological catch-up at both micro (firm level) and meso (industry) level that can lead to sustainable production. An important pathway to addressing this dilemma is via new technology adoption and its implementation that can contribute to sustainability.

For a given problem context, a technological transition refers to major changes to the ways in which the technological solutions are developed, the principles of science they are based on, and the forms they take. For rational policy design vis-à-vis GM crops and other new technologies to come in crop production, it is important to understand the problems associated to ensuring sustainability and technological catch up during major technology transitions. Therefore, the purpose of this thesis is to examine possible answers to the central question: What are the drivers of sustainability and catch-up in the context of technology transitions in agriculture?

To answer this overarching question, an examination of the evolution of GR and GM technologies in an emerging country such as India can provide valuable insight.

Why India? By the mid-1960s, due to increasing demand and lagging agricultural production there was severe food shortage in India. This challenge was resolved by the integration of GR technologies in Indian agriculture. While the success of GR in improving the yields across several crops and contributing to the economic wellbeing of farmers in India is well recognized, the same began to come under increasing scrutiny due to evidence of environmental degradation that started surfacing from the mid-1980s. Thus, the evolution of GR in India can be useful to understand how new technologies should be promoted from the sustainability angle.

By the start of the new millennium cotton yields in India were among the lowest in world while the pesticide consumption was as high as $54 \%$ of the total pesticide consumption in the country (Raghuram, 2002). This challenge was resolved by the adoption of a GM cotton variety known as Bt (Bacillus thuringiensis) cotton as the pesticide producing genes of bacterium Bt were incorporated into cotton plant.

By 2013, about 7.32 million farmers had planted roughly 11 million hectares of land with Bt cotton, ranking India fourth in the world in terms of land devoted to GM plant varieties, after the US, Brazil and Argentina. The Bt cotton area increased from less than $10 \%$ of the total cotton area in 2004 to more than $95 \%$ in 2013 (James, 2013). This enthusiasm of farmers signaled not only the market success of the technology but a major transition in input technologies. 
While starting late 1980s private firms became active in the hybrid seeds market in India, the market success of Bt cotton brought significant changes to firms' investments in developing Bt varieties in vegetables and field crops. The biotech related R\&D investments by these firms for developing GM hybrids in cotton (and other crops), molecular markers and related tools grew from approximately USD 17 million to USD 490 million between 2002-03 and 2011-12 (ABLE-Biospectrum biotech industry surveys 2002-2012). Some of these firms therefore became natural partners for MNEs like Monsanto.

Despite this immense commercial success, societal debates on the long term environmental and livelihood impact of Bt adoption continued. For instance, in 2009, Mahyco in collaboration with Monsanto applied for authorization to bring out a genetically modified vegetable variety, Bt brinjal into the Indian market. However, after this was granted by GEAC, there was an outcry from civil society groups and anti-GM activists. Thus, in order to appease them, the Ministry of Environment deemed it necessary to review the performance of Bt cotton, India's first GM crop by a series of public debates. Opinion was divided even among the scientists and the Minister had to impose an indefinite moratorium on the open field trials of Bt brinjal (MoEF, 2010).

In 2014, this policy stance was nevertheless entirely reversed with the ushering of a new neo-liberal government. In July 2014 GEAC cleared the approval of field trials for a range of food crops including rice, mustard, cotton, chickpea and brinjal (Menon, 2014). In Nov 2014 the Minister of Environment asserted in the parliament that there is no official ban on GM crops research and any such ban would be against national interest (PTI, 2014).

From the above, it is clear that the study of the introduction and triumph of Bt cotton in India forms an ideal base to understand the rational of actors that are responsible for generation and diffusion of new technologies in agriculture such as the State (Government), public sector research bodies, MNEs, local firms, and farmers. Thus, the most important questions relevant to each of these actors in the context of technological transitions will be addressed by the thesis. Now, I present the set of sub-questions through which the central research question will be addressed.

Starting at the systemic level, any major technological transition tends to create winners and losers among the actors of the innovation system. As a consequence, technology transitions are often marked by controversies or prolonged public debates on the possible impacts of new technology integration. The transitions to GR technologies and GM cotton in India were no exceptions to this rule. But, the existing literature does not provide us with a clear understanding of how contro- 
versies emerge in the wake of major technological transitions. Therefore the first question the thesis tackles is how do controversies come about during major technology transitions in agriculture?

Moving then to farmers, the thesis integrates an often overlooked reality, namely that of heterogeneity in terms of perceptions and preferences. They may exhibit different preferences for sustainable technologies or sustainable implementation practices. However, farmers who opt for non-sustainable implementation can engender new production problems requiring other actors in the innovation system to invest in technological search or other forms of solutions which are costly. Thus, in order to understand the dynamics of sustainability from the perspective of farmers, the thesis addresses a second question, how are sustainability concerns integrated in drivers of new technology adoption by farmers? This question is important to understand not only the determinants of adopter behaviour but also to what extent do uncertainties about new technologies affect the direction of technological transitions in agriculture, the sustainability of agricultural practices and the rate of catch up.

Next, turning to seed firms, there are two interesting aspects that oblige research attention. First, with the rise of biotechnology the innovation trajectories are increasingly dictated by the strategies of private actors. Private sector catch up is inevitably a must do for emerging countries where public sector is lagging and not delivering. This feature is part and parcel of characteristics of technology paradigm shifts in modern era which cannot be brushed away. Further globalization has facilitated not only the strong emergence of MNEs, but also the geographical proliferation of innovation activities. At the same time the recent economics and international business literature suggests that local actors are playing an important role in the global production and innovation networks. Given the access to technologies and the proximity to local agro-ecology, the local firms can potentially catch up with advanced technologies in quick time. However, little attention has been paid to studying this particular aspect of technological catch-up in agricultural innovation. Therefore this thesis examines a third question: What are the catchup strategies of local firms vis-a-vis new agricultural technologies?

Finally, the establishment of MNEs as the agricultural technology holders has raised concerns among emerging country stake-holders. Given the technological prowess of the MNEs, it is a win-win for MNEs and emerging countries to tap into this scientific potential. This is especially a realistic proposition in essential commodities such as agricultural inputs and medicines where MNEs dominate. Therefore it is a must for a policy maker to step into the shoes of MNEs. In this context the localization of radical innovations, i.e, successful market introduction of radically new products or processes after being adapted to local conditions is a chal- 
lenge for MNEs. Localization of GM crops and their underlying technology poses special challenges for foreign MNEs in emerging countries. Therefore localization of radical innovations such as GM crops and their underlying technology poses special challenges for foreign MNEs in emerging countries. On the one hand, these countries offer new and growing markets, cheap sources of qualified labour and sites for production where the regulatory costs are less. On the other hand, if the products such as GM crops entail social, economic and ecological uncertainties, and if there is a trust deficit between the foreign firm and the key stake-holders in the innovation eco-system, the success of commercialization of the new technology may be put at risk. Therefore, from the perspective of a foreign MNE trying to introduce its radical innovation into an emerging country, it faces the question -what is the best strategy to localize such products or technology? As a large part the literature on localization strategies of MNE innovations mostly assumes that the innovation (product or its associated technology) to be introduced in a target region has already earned its legitimacy, the question what constitutes the localization strategy of a MNE to achieve legitimacy of its radical innovations in emerging countries?, forms the fourth enquiry of the thesis.

This completes the rationale for the research foci of the thesis.

\subsection{Methodology and organization of the thesis}

In order to identify the gaps and highlight a set of theoretical elements Chapter 2 reviews the literature on the evolution of systems of innovation thinking and the drivers of changes to these systems. This is followed by the development of a theoretical construct that portrays technological transitions. Further some of the elements of this theoretical construct are illustrated by agriculture technologies, in general, and in particular by the empirical insights of GR and GM cotton transitions in India.

Chapter 3 illustrates the nature of economic and ecological outcomes that characterize technological transitions in agriculture and its implication for sustainability via a systematic review of the impact literature on GR and Bt cotton in India. Systematic reviews of literature by the application of bibliometric search and metaanalysis are very useful to comprehend the characteristics of the existing evidence or knowledge on a given topic.

Chapter 4 looks into how controversies emerge during major technology transitions in agriculture? A theoretical framework identifying the potential loci of controversies during diverse stages of a technology transition is developed and applied to analyse India's GR and GM transitions. A mixed empirical method of historical reconstruction and insights from farmer survey is applied to answer the central question. Historical reconstruction and case study analysis are best suited 
when the analysis constitutes understanding the 'how' rather than 'why' of an underlying process (Yin, 2002; Eisenhardt, 1989). In this chapter, the 'how' is with respect to the emergence of controversies during technology paradigm shifts.

Chapter 5 examines the question of how sustainability concerns are integrated in drivers of new technology adoption by farmers. A novel model of new technology adoption integrating the ideas of built-in seed technology obsolescence and farmer heterogeneity is formulated and tested. Empirical models of perceptions of economic and ecological impacts are constructed and applied to the survey data of $\mathrm{Bt}$ cotton farmers using statistical techniques. Statistical analysis provides a better understanding of the underlying relationships between variables of interest, and to measure the direction of changes to these relationships.

Chapter 6 analyses the catch up strategies of Indian firms with respect to capabilities development in agri-biotechnology. It conceptualizes the knowledge base required for agricultural innovation against the backdrop of globalization and rise of biotechnology. The framework is then applied to examine the case of catching up of Indian seed firms with Bt technology in cotton hybrids. The case study is complemented by the analysis of secondary data on Indian cotton seeds market and insights from the qualitative interviews of a set of stake-holders.

Chapter 7 throws light on the localization strategies of foreign multinational firms in the context of introducing radical innovations such as Bt insect resistance technology in emerging countries. A conceptual framework is developed and applied to the case of Monsanto and its introduction of Bt technology in India to draw insights.

Chapter 8 presents the concluding remarks on the main results and insights for policy design and firm strategy.

The research questions/objectives and the corresponding methodologies applied to achieve them, chapter wise, are summarized in Table 1.1.

Multiple sources of data, both primary and secondary, are used as an empirical base for the analysis in the thesis and the overall methodology is mixed. This multipronged approach to answer the central research question provides a strong base for arriving at insights that constitute a grounded theory (Glaser and Strauss, 2009). 
Table 1.1 Methodology and organization of thesis

\begin{tabular}{|c|c|c|}
\hline Chapter & $\begin{array}{l}\text { Question or objectives and the broader } \\
\text { issue it relates to. }\end{array}$ & Methodology \\
\hline 2 & $\begin{array}{l}\text { What are the drivers of the evolution of } \\
\text { technology paradigms? }\end{array}$ & $\begin{array}{l}\text { Review of literature on systems of innovation. } \\
\text { Formulation of a theoretical construct. } \\
\text { Illustration using crop production technologies. }\end{array}$ \\
\hline 3 & $\begin{array}{l}\text { What is the nature of economic and eco- } \\
\text { logical outcomes of technological transi- } \\
\text { tions in agriculture? - relates to drivers of } \\
\text { sustainability. }\end{array}$ & $\begin{array}{l}\text { Systematic review of literature and meta- } \\
\text { analysis. }\end{array}$ \\
\hline 4 & $\begin{array}{l}\text { How do controversies come about during } \\
\text { the emergence and diffusion of radically } \\
\text { new technologies? - relates to drivers of } \\
\text { sustainability. }\end{array}$ & $\begin{array}{l}\text { Formulation of a theoretical construct. } \\
\text { Historical reconstruction. } \\
\text { Analysis of farmer survey data. }\end{array}$ \\
\hline 5 & $\begin{array}{l}\text { To what extent the preferences of farmers } \\
\text { affect the sustainability of their agricul- } \\
\text { tural practices? - relates to drivers of } \\
\text { sustainability. }\end{array}$ & $\begin{array}{l}\text { sFormulation of a theoretical model. } \\
\text { Statistical analysis of farmer survey data. }\end{array}$ \\
\hline 6 & $\begin{array}{l}\text { What are the possible catch-up strategies } \\
\text { of local firms vis-a-vis GM seeds? - relates } \\
\text { to drivers of catch up. }\end{array}$ & $\begin{array}{l}\text { Formulation of a theoretical construct. } \\
\text { Case study analysis. } \\
\text { Analysis of secondary data and data from qualita- } \\
\text { tive interviews. }\end{array}$ \\
\hline 7 & $\begin{array}{l}\text { What constitutes the best localization } \\
\text { strategy for multinational firms with } \\
\text { respect to radical innovations in emerging } \\
\text { countries? - relates to drivers of catch up. }\end{array}$ & $\begin{array}{l}\text { Formulation of a theoretical construct. } \\
\text { Case study analysis. }\end{array}$ \\
\hline
\end{tabular}

For getting familiar with the scientific nitty-gritty of crop production technologies in general and agri-biotech methods in particular, and in order to interact with farmers and key informants of the sector, the institutional support of Agri Biotech Foundation (ABF India) is taken. Additionally personal networks in the private seed firms of India also came in handy for interviewing some key informants in the Indian seed sector.

At this juncture, some limitations of this methodological and empirical approach also need to be acknowledged. A theoretical construct can only serve to illustrate a phenomenon or to postulate a theory but does not constitute a theory in itself. Similarly, while case study analyses are useful to understand processes, they can only give indicators of cause and effect. On another note, the primary data utilized in this thesis is based on a survey of 127 farmers and qualitative interviews with 27 individuals representing key informants on Indian agricultural innovation system. The selected sample of farmers may not represent the thousands of Indian farmers growing Bt cotton, and the sample of informants interviewed cannot represent all stake-holders. However the samples are deemed adequate for providing necessary empirical insights for the research queries. Nevertheless, these limitations have been kept in mind while drawing inferences. 



\section{Chapter 2. Towards a theoretical framework of technology par- adigm shift}

\subsection{Evolution of thought on innovation: From linear to systemic view}

Invention refers to a new product or a process. Innovation on the other hand is a change that can occur in technological, social or organizational contexts that has a potential commercial value. The changes embedded in innovations can range from being entirely novel to just constituting a minor improvement. Several scholars in economics as well as business have studied the processes by which innovations emerge. Linear models of innovation suggest that research and development happens in a linear fashion, where public or private sector scientific knowledge reaches consumers via applied technologies developed by firms (Nelson, 1959). In contrast, a system of innovation thinking assumes that new products, processes and new forms of organization (innovations) are brought into social and economic use by a network of actor-organizations. This also includes the institutions and policies that affect the behaviour of the actors and the outcomes. Systems of innovation thinking can be traced back to the 1980s when it emerged as a strong alternative to linear models of innovation.

According to the systems school, the generation and diffusion of innovations occurs through interaction between varieties of actors not necessarily connected in a liner fashion. An actor-network further defines the relationships between actors' and identifies the role of key actors (for instance, State) who are more important than others in terms of influencing the outcomes. These actors and their networks are self-organizing in real time given the changing set of rules that govern the system. Various types of co-ordination and information flow problems are possible along networks between actor types. For example, co-ordination problems could necessitate investments to foster public-private partnerships in research, university-industry collaboration in technology development and commercialization. Dealing with co-ordination failure may involve changing regulation or enhancing information flow by dealing with bottle necks or blockages. While systems approach also oversimplifies the representation of a complex world, it is nevertheless realistic.

The 'system' that typifies the process of innovation generation and diffusion has been portrayed in diverse ways by several scholars. Table 2.1 summarizes the main conceptualizations that typify the systems of innovation. While some of the representations are centered on the technological artifacts, organizations and related materials (Hughes, 1987), some take stock of the key stake holders as well as the rules of the game (regulation and policies) in a national, regional or sectoral context (Lundvall, 1992; Nelson, 1993; Malerba, 2002). Others centre on the tech- 
nological artifacts and the underlying system of economic actors (Carlsson and Stankiewicz, 1991) and finally there is a very broad grouping of all these elements (Geels, 2004; Geels, 2005; Geels and Kemp, 2007).

Table 2.1 Evolution of systems of innovation concepts

\begin{tabular}{|c|c|c|}
\hline Author/s (Year) & Notion & Representation \\
\hline Hughes (1987) & Large Technological systems & $\begin{array}{l}\text { Physical artifacts (machines, tools etc) } \\
\text { and Organizations constructed and } \\
\text { being shaped by societies. }\end{array}$ \\
\hline Carlsson and Stankiewicz (1991) & Technological systems & $\begin{array}{l}\text { Network of agents interacting in a } \\
\text { particular technology area exchanging } \\
\text { knowledge and competencies. }\end{array}$ \\
\hline Lundvall (1992); Nelson (1993) & $\begin{array}{l}\text { National Systems of Innova- } \\
\text { tion }\end{array}$ & $\begin{array}{l}\text { The structure comprising economic } \\
\text { actors who are responsible for the } \\
\text { creation, development, diffusion and } \\
\text { adoption of innovations within a } \\
\text { country. }\end{array}$ \\
\hline Malerba $(2002,2004)$ & Sectoral systems of innovation & $\begin{array}{l}\text { System comprising of Knowledge and } \\
\text { technology, actors and networks, and } \\
\text { institutions specific to a sector. }\end{array}$ \\
\hline $\begin{array}{l}\text { Geels (2004, 2005); Geels and } \\
\text { Kemp (2007) }\end{array}$ & Socio-technical systems & $\begin{array}{l}\text { Clusters of elements involving tech- } \\
\text { nology, science, regulation, user prac- } \\
\text { tices, markets, cultural meaning, } \\
\text { infrastructure, and production and } \\
\text { supply networks. }\end{array}$ \\
\hline
\end{tabular}

From this exercise one can identify three basic building blocks of innovation systems. First, there is the actor network. Second, there are tangible technical and non-technical artifacts. Third, there are a variety of intangible elements such as rules, actions, functions, policies etc.

Systemic outcomes can change with changes to the following: first, the efficiency of individual actors, second, the networks that connect the individual actors and the rules governing the interactions in the network, and third, the structure of the system (composition, variety and number of actors). Functional exploration in systems therefore involves studying the overall construct, functioning of individual actors and their interactions. Examining the change aspects of systems on the other hand involves understanding the processes that drive the larger changes to the system, for instance, the forces that trigger the emergence, stability and collapse of systemic structures or the system itself. Therefore, in the context of systems, one can analyse either the functional aspects or the change aspects (Geels and Kemp, 2007). The thesis is interested in the change aspects.

How can the functional and change aspects of innovation system be better understood theoretically? To this end, the application of evolutionary principles (Nelson 
and Winter, 1982) made a great contribution. Here, the dynamics of actors' (firms') behaviour and subsequent market outcomes are explained in terms of biological evolution. The rule-based 'routines' that determine a firm's behaviour are similar to 'programs' of genes in a biological setting. In evolutionary biology, a random 'mutation' can potentially create a new species. The follow through of such mutations creates 'variation' in the species. Variation creates new sets of genes out of which only a few get selected into the population of the species. The concepts of variation and selection are powerful tools to understand the construct, functioning and evolution of innovation systems.

Within this broader framework of evolutionary dynamics, Nelson and Winter (1982) introduce the notion of technological regimes referring to the similarities in the organization of the search heuristics that dominate the actors' (engineers' and scientists') behaviour to innovate. Technological evolution in general is characterized by regimes and trajectories. A regime specifies a dominant pattern of behaviour that the actors follow to come about with solutions to problems. Their behaviour, for instance, in searching for technological solutions, is based on established cognitive 'routines' or 'heuristics' (rule-based) that push a 'technological trajectory' in a particular direction. Here, the evolution of technological regimes is explained in terms variation and selection. While 'variation' refers to emergence of a new set of technology search routines, 'selection' determines their fate. Search routines that survive the selection mechanism stay put in the system. Further, the innovation system is characterized by simultaneous search and selection processes that not only influence the direction of technological evolution but also lead to the rise and fall of economic actors as both winners and losers reconcile their search routines.

At around the same time, Dosi (1982) proposed the notion of 'technology paradigms' and characterized the change processes within the technology paradigms as 'trajectories'. Here a technological paradigm is "a model and a pattern of solution for selected problems based on selected principles derived from natural sciences and on selected material technologies". A technological trajectory is "a pattern of normal problem solving activity on the grounds of such a technological paradigm". Further, changes to the system (or technological evolution) are explained from the perspective of changes to the supply and demand of technologies.

Sahal (1985) propose that technological evolution is guided along the innovation avenues by certain guide posts. The guide posts are discovered by chance and necessity. Later on Perez $(2004 ; 2009)$ explains technological evolution in terms of radical and incremental innovations. Here evolution is dictated by emergence of radical innovations (revolutions) and is shaped by the incremental innovations 
that are developed by means of technological efforts in the same direction as that of the radical innovation.

Technological evolution is also explained by the entry of niche innovations into existing technology regimes (Rip and Kemp, 1998). As a major shift to regimes entails changes to societal as well as technological configurations these are seen as socio-technical transitions. In the tradition of socio-technical transitions Kemp et al. (1998) and Geels(2002; 2004; 2005) explain the transition dynamics in the technology regimes from the perspective of niche innovations. From a multi-level perspective introduced by Geels(2002) innovations from the niche region (level 0) enter into the existing regimes (level 1) that are opened up by pressures exerted by the changes external to the regime, that is, from the socio-technical landscape (level 2). Further, the change processes as well as the typology of transition pathways are explained using the multi-level perspective (Geels and Kemp, 2007; Geels and Schot, 2007). While Geels and Kemp (2007) typify the change processes as reproduction, transformation and transition, Geels and Schot (2007) typify the transition pathways as transformation, de-alignment and re-alignment, and technological substitution. The concepts that typify the change processes within innovation systems are summarized in Table 2.2.

Table 2.2 Concepts that typify technological evolution within systems thinking

\begin{tabular}{ll}
\hline Author/s (Year) & Concepts \\
\hline Nelson and Winter (1982) & Technological regimes and Trajectories \\
Dosi (1982) & Technological paradigms and Trajectories \\
Sahal (1985) & Technological guide posts and innovation avenues \\
Kemp et al. (1998), Rip and Kemp (1998) & Niches and Regime shifts \\
Perez (2004, 2009) & Technological revolutions and Paradigm shifts \\
Geels $(2002,2004,2007)$ & Technological transitions in a multi-level perspec- \\
& tive and transition pathways \\
\hline
\end{tabular}

As Table 2.2 indicates although the terminology varies all these scholars are interested in explaining the rise and fall of technological regimes, the evolution of technological solutions within those regimes and their socio-economic implications. Now we will see the explanations for selection, emergence and dominance of technology paradigms.

As pointed out earlier, selection is central to the evolutionary explanation of economic dynamics. There is a selection mechanism prevalent in an innovation system such that for each configuration of a set of problems, through the strategic actions of economic actors a dominant technology emerges over time. Its success in turn opens the door for scores of incremental innovations on top of it making a complete paradigm emerge over time. 
The emergence and selection of a paradigm is explained by the push-pull dynamics in the system i.e., the science-push and demand-pull of the markets (Dosi, 1988). Here scientific fields of enquiry are seen as purely supply driven and are highly dependent on the existing knowledge base. Any major development here increases the possibility of emergence of a new paradigm. On the other hand, the market demand determines the diffusion of individual technologies. The market success of innovations dictates that the suppliers of innovations invest in incremental technologies based on existing ones while unsuccessful innovations eventually die out and technological progress proceeds in that direction.

For comprehending drivers of the stability (or inertia) of a technology paradigm, historical events and path dependence (David, 1985) are useful arguments. Increasing returns and path dependence reinforce the strength of a dominant technology that in turn increases the inertia of the technologies within a paradigm. Stability eventually leads to dominance which in turn can lead to situation called 'lock-in' (Arthur, 1990; Arthur, 1989; Cowan, 1990; Cowan and Gunby, 1996) where in an efficient technology gets killed while competing with an inefficient one due to increasing returns to adoption, positive feedbacks and network externalities. The efficiency here is economic. This makes a technology paradigm shift difficult for that particular set of problems. The same forces also prevent the transition towards sustainable technologies for that problem. Explicit policy intervention that can create niches might be necessary to break the lock-in (Cowan, 1996).

Technological solutions for a given problem, therefore, can be placed under the umbrella of a technology paradigm which emerge as a result of scientific endeavours, get selected by the strategies of economic actors and eventually dominates the system as a result of systemic forces. For a given problem set, a technological paradigm shift or technological transition is therefore a shift from one dominant paradigm to another. Technology paradigm shifts and technology transitions are used interchangeably in the thesis.

Recalling the definition of sustainable technology, it is referred to as a technology which is socially acceptable, economically profitable and environmentally friendly. In systems of innovation literature, Kemp and Soete (1992) and Kemp (1994) explicitly link technology transitions to sustainability. During the later years more empirical efforts threw light on the dynamics of technology transitions, particularly on technological transitions towards sustainability. For instance, while Kemp (1994; 1998) identifies the hurdles for the transition towards green technologies in energy and sustainable waste management, Schot et al. (1994) propose strategies for transition to electrical vehicles. Several of these empirical studies analyse the transitions to sustainable technologies in the framework of societal functions such as energy, transportation, waste management etc. However, the application of 
the technology transitions framework to a broad range of crop production technologies is limited.

\subsection{Theoretical construct}

We start by defining the following.

Problem space P: This refers to the set of existing production problems.

Consider $\mathrm{z}$ problems that denote all the production challenges at a given point of time. Let the problem space be given by $P=\left\{\mathrm{p}_{1}, \mathrm{p}_{2}, \ldots \ldots, \mathrm{p}_{\mathrm{z}}\right\}$.

Technological solution space T: A technological solution can be a 'tool' or a 'method' to tackle the problems in $\mathrm{P}$.

Let $\mathrm{T}=\left\{\mathrm{t}_{1}, \mathrm{t}_{2}, \ldots \mathrm{t}_{\mathrm{p}} \ldots \ldots, \mathrm{t}_{\mathrm{m}}\right\}$ be the set of $\mathrm{m}$ existing technological solutions for the problems in $\mathrm{P}$.

Scientific principles space S: This represents the existing base of scientific principles on which the solutions can be based.

Let $S=\left\{\mathrm{s}_{1}, \mathrm{~s}_{2}, \ldots \mathrm{s}_{\mathrm{i}} \ldots \ldots, \mathrm{s}_{\mathrm{n}}\right\}$ be the set of $\mathrm{n}$ scientific principles through which solutions for the set of problems in $\mathrm{P}$ can be searched for.

Global Technology Paradigm Space: A global technology paradigm space (GTPS)is in three dimensions, wherein any point in GTPS represents a problem $\mathrm{p}$ from $\mathrm{P}, \mathrm{a}$ technology solution $\mathrm{t}$ from $\mathrm{T}$ and a scientific principle s from $\mathrm{S}$ respectively. Every point in this space is therefore a triplet.

$$
\text { GTPS }=\{(p, t, s) \subseteq \operatorname{PxTxS}\}
$$

Technology paradigm: A technology paradigm is a set of points (which can be imagined as 3D balls) in the Global Technology Paradigm Space which represents a set of problem-solution-scientific principle triplets.

Let $\mathrm{P}^{*}$ represent a possible set of related problems.

Let $\mathrm{T}_{\mathrm{P}^{*}}$ represent a set of possible technological solutions for problem set $\mathrm{P}^{*}$. This can be an empty set if there are no available technology solutions at a given point of time. For simplicity, we only focus on problems $\mathrm{P}^{*}$ for which the technology solution set $\mathrm{T}_{\mathrm{P}^{*}}$ is non-empty. Furthermore, we make the following assumption. 
Assumption: Consider a problemp $\mathrm{p}_{\mathrm{i}}$ from P. For every specific technological tiont $_{\mathrm{pi}}$ in $\mathrm{T}_{\mathrm{p}}$ for problem $\mathrm{p}_{\mathrm{i}}$ in $\mathrm{P}$, there exists a unique scientific principle $\mathrm{s}_{\mathrm{pi}}$ that supports it. Then let $\left(t_{p i}, s_{p i}\right)$ represent such a problem-scientific principle pair.

Let $\mathrm{S}_{\mathrm{P}^{*}}$ be the set of scientific principles corresponding to technology solutions in $\mathrm{T}_{\mathrm{P}^{*}}$.

Then a technology paradigm $\mathrm{G}_{\mathrm{P}^{*}}$ can be defined as follows:

$$
\mathrm{G}_{\mathrm{P}^{*}}=\left\{\left(\mathrm{p}_{\mathrm{i}}, \mathrm{t}_{\mathrm{pi}}, \mathrm{s}_{\mathrm{pi}}\right)\right\} \text { where } \mathrm{p} \in \mathrm{P}^{*} \subseteq \mathrm{P} ; \mathrm{t}_{\mathrm{pi}} \in \mathrm{T}_{\mathrm{P}^{*}} \subseteq \mathrm{T} ; \mathrm{s}_{\mathrm{pi}} \in \mathrm{S}_{\mathrm{P}^{*}} \subseteq \mathrm{S} \text {. }
$$

According to the above equation a technology paradigm $\mathrm{G}_{\mathrm{P}^{*}}$ thus represents a set of related problems $\mathrm{P}^{*}$, a set of technology solutions $\mathrm{T}_{\mathrm{P}^{*}}$ for these problems, which are in turn based on a set of scientific principlesS $\mathrm{P}_{\mathrm{P}^{*}}$.

Technology landscape for problemp $\mathrm{p}_{\mathrm{i}}$ : Consider a problemp $\mathrm{p}_{\mathrm{i}}$ from $\mathrm{P}$. Let $\mathrm{T}_{\mathrm{pi}}$ be the set of technology solutions for this problem and let $S_{p i}$ be the set of supporting scientific principles corresponding to every technology solution in $\mathrm{T}_{\mathrm{pi}}$.

Then the technology landscape ${ }^{1}$ corresponding to a given problemp $\mathrm{p}_{\mathrm{i}}$ from $\mathrm{P}$ can be defined as $\mathrm{L}_{\mathrm{pi}}$, a plane containing all technological solutions for problemp $\mathrm{p}_{\mathrm{i}}$, and for each technological solution, the corresponding supporting scientific principle. Thus, we have:

$$
\mathrm{L}_{\mathrm{pi}}=\left\{(\mathrm{t}, \mathrm{s}) \in \mathrm{R}^{2}\right\} \text { where } t \in \mathrm{T}_{\mathrm{pi}} ; \mathrm{s} \in \mathrm{S}_{\mathrm{pi}} \text {. }
$$

To illustrate the definitions so far in Figure 2.1 we designate on the X-axis, the problems, on the Z-axis all possible solutions and on the Y-axis all scientific fields. Since we are representing a three dimensional space the 'balls' represents the 'production problem-technology solution-scientific-principle triplets' wherein each ball refers to a specific problem, a corresponding technological solution and the scientific principle on which the solution is based. Filled balls and unfilled balls represent two technology paradigms for a set of related problems.

\footnotetext{
1 This conceptualization of technology landscape is different from the 'socio-technical landscape' of Rip and Kemp (1998) and Geels (2007) in which it represents the tangible structures and elements (such as infrastructure) that act as 'gradients of force' that bring about changes at the regime level. The term is used in a more general and metaphorical way to represent a 'binding structure' of related technology and science tuples.
} 


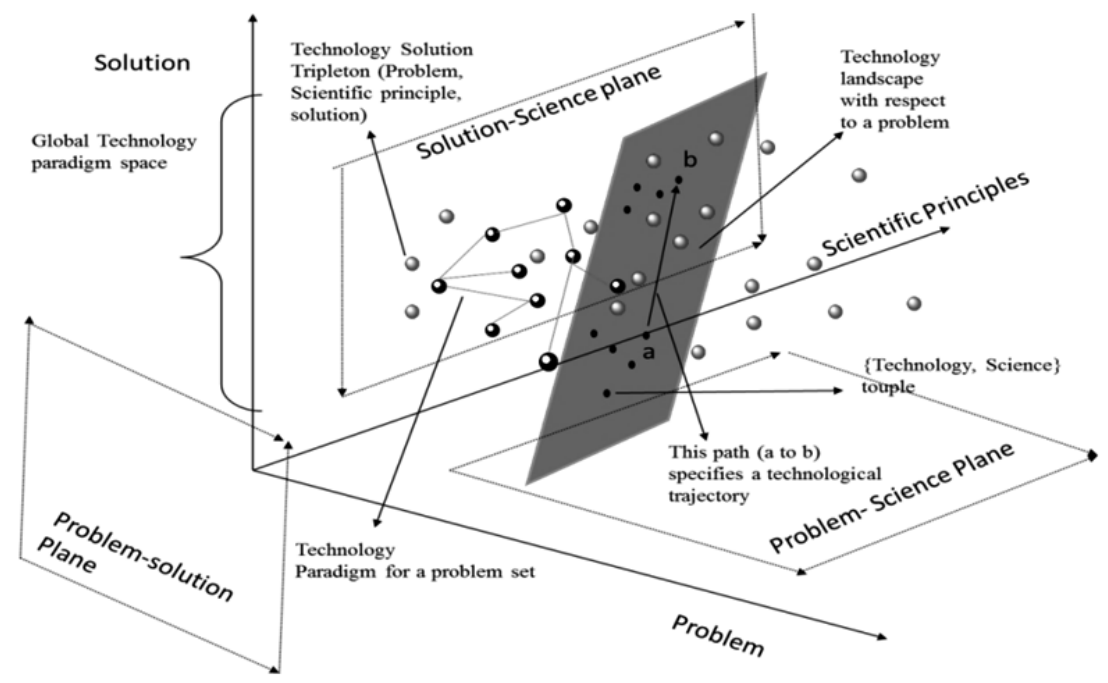

Figure 2.1 Global Technology Paradigm Space

In order to explain the triggering mechanism of a paradigm shift we now to turn to actor strategies in the system.

Economic actors and Ecology in an innovation system: Consider an innovation system that is made up of a set of economic actors and Ecology. Economic actors include players like State (policy makers), private firms, public sector institutions, consumers etc. Ecology on the other hand is a set of non-economic entities such as soil, water, pests and micro-organisms, that is, the biological and physical elements, which respond to the strategies of economic actors based on a set of rules (bio-physical rules).

Response function of Ecology: Let us consider a problem $\mathrm{p}_{\mathrm{i}}$ at time $\mathrm{t}$ and a solution $t_{i}$ at time $t$, and let $f$ be the response function of Ecology. The response function gives the response of the biological and physical elements over time to the technologies implemented at present.

$$
p_{i}(t+1)=f\left(\left(p_{i}(t), t_{p i}(t)\right) \text { where } p_{i}(t+1) \in P\right.
$$

$\mathrm{p}_{\mathrm{i}}(\mathrm{t}+1)$ may encompass problems that undermine production.

Technology paradigm shift and technology trajectory corresponding to a lem $\mathrm{p}_{\mathrm{i}}$ : Let $\mathrm{a}$ and $\mathrm{b}$ be two points in the technology landscape Lpi. The movement from a to $b$ represents a technology paradigm shift with respect to problem $p_{i}$. 
The path traced to move from one point to another within $\mathrm{L}_{\mathrm{pi}}$ is a technology trajectory for the problem $p_{i}$.

Technology transition or paradigm shift: A technology transition is a process that involves the following stages:

For a set of production problems $\mathrm{p}$ technology search takes place in the global technology paradigm space.

Emergence and selection of paradigms occur as an outcome of strategies of economic actors.

Out of the paradigms selected, one paradigm emerges as the dominant one as an outcome of strategies of economic actors.

For the technology solution $t_{p i}$ that forms part of the dominant technology paradigm selected by the system, the Ecology responds with the response function $f$ $\left(\mathrm{p}_{\mathrm{i}}, \mathrm{t}_{\mathrm{pi}}\right)$.

Economic outcomes occur and new problems are recognized.

Finally there is a return to technology search.

Figure 2.2 depicts the process of technology transition in the global technology paradigm space where search, emergence, selection, and the ecological response are depicted.

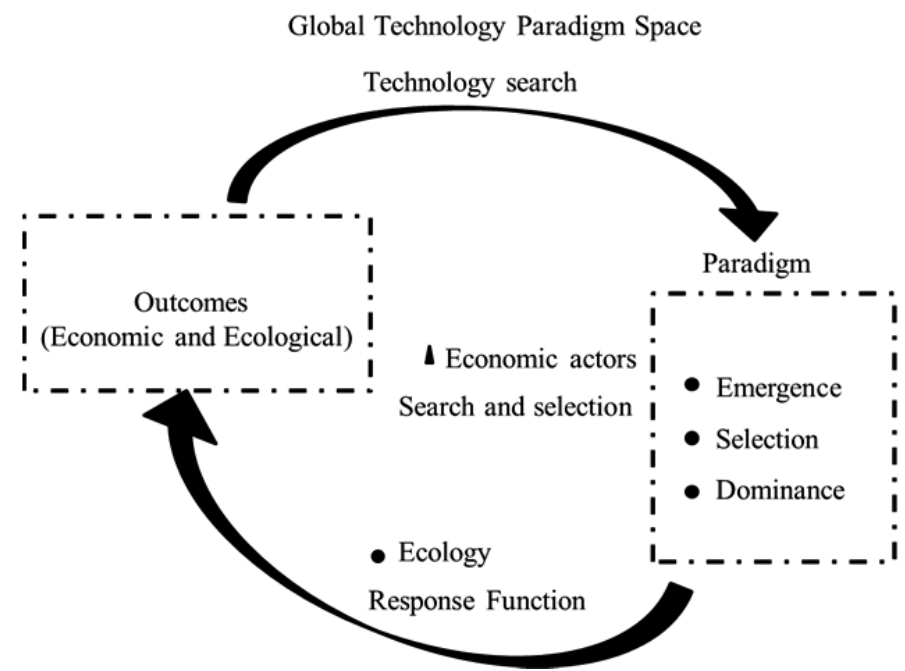

Figure 2.2 Technology paradigm shift 
This completes the theoretical construct.

Since the process of a technology transition is difficult to model and test in its entirety using data sets, in order to analyse the technology transition process and its underlying mechanisms, historical reconstruction and case study analyses are applied to answer some research questions in the thesis.

\subsection{Illustration of theoretical elements from crop production problems}

Problem space P: Productivity problems in agriculture are broadly pertinent to achieving higher yields or saving the labour efforts. All problems related to either form the problem space $P$.

Technological solution space T: Labour productivity can increase through use of mechanical machinery like tractors, mechanical ploughs, sowing machines and harvesting machines. Land productivity (yield) can be improved through improvements in biological and chemical inputs like improved seeds, fertilizers and pesticides.

Scientific Principle Space S: Principles of Mendelian genetics ${ }^{2}$, principles of fundamental plant sciences such as botany, plant biology, plant physiology (science that determines the shape and size of a plant), plant pathology (study of susceptence to pathogens/diseases), entomology (study of insect populations and their behaviour towards a host plant species), principles of plant genetics (study of structure and changes to DNA), molecular biology (study of DNA, RNA and proteins) which include methods of genetic engineering, micro-propagation (tissue culture), and marker assisted breeding, and principles of microbiology (study of microorganisms), principles of bio-informatics, principles of mechanics, hydraulics, electrical ,electronic, instrumentation engineering are some of the scientific principles that form the Scientific Principle Space.

Problem set $P^{*}$ from P: Problem of lower yields ( $\left.\mathrm{P}^{*}\right)$ lies within the problem space $P$. It is a set of related problems which may source from inferior germplasm, susceptibility to insect pests and diseases (physiological), non-resilience to a given agro-ecology, and inability to produce more because of inferior morphological characteristics, for example, weak stalks in field crops.

\footnotetext{
${ }^{2}$ As early as 1856, Gregor Mendel through his experiments with pea plants discovered that plant traits are passed from parents to off springs and therefore cross breeding between selected parents would produce off springs with desired traits.
} 
Technological solution set for problem set $P^{*}, \boldsymbol{T}_{p^{*}}$ The solution for lower yields (p) appear in the form of improved seeds (high yielding plant varieties/hybrids), fertilizers, pesticides, herbicides or a genetically modified hybrid seed (example is round-up ready hybrid that takes care of insects, weeds as well as higher yields).

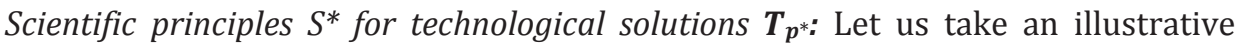
problem of producing an insect resistant GM plant variety within $\mathrm{P}^{*}$ which broadly involves two steps: 1. Extraction of the source gene and 2. Transfer of the gene. The solution for step1 is found by applying the principles of molecular biology while the solution for step2 is achieved via principles of Bio-chemistry.

Technology solution-Scientific principle pair: Continuing with previous example the extracting the source gene is done by 'molecular markers' developed using principles of molecular biology, and gene transfer is accomplished using a particular tool 'gene gun' based on principles of bio-chemistry. Then (molecular markers, a supporting principle of molecular biology) and (Gene gun, a supporting principle of Bio-chemistry) each represent the (technological solution, supporting scientific principle) couple for steps 1 and 2 respectively.

Global Technology Paradigm Space: This space for crop production involves all possible (problem, technological solution and scientific principle) triplets from P, T and $\mathrm{S}$ as described above.

Technology paradigm: Crop production technologies are broadly characterized by early green revolution technologies (Modern Varieties - 1960s till 1980s), late green revolution technologies (Hybrids- 1980s till date), biotechnologies (GM crops and biotech aided breeding techniques) and agro-ecological technologies (less resource intensive practices). However, if the early and late green revolution paradigms are to be combined to represent a conventional paradigm of crop production technologies we can clearly envisage the conceptual differences in the nature and makeup of the technological solutions being offered by each of these paradigms as illustrated in Table 2.3. 
Table 2.3 Classification of technology paradigms in crop production technologies

\begin{tabular}{|c|c|c|c|}
\hline & Conventional & Biotech & Agro-ecological \\
\hline Solution platform & $\begin{array}{l}\text { Modern Varieties, synthetic } \\
\text { fertilizers, pesticides, herbi- } \\
\text { cides + package of practices }\end{array}$ & $\begin{array}{l}\text { GM seeds + package } \\
\text { of practices }\end{array}$ & $\begin{array}{l}\text { Bio-fertilizers, bio-pesticides, } \\
\text { integrated pest management } \\
\text { and other resource conserva- } \\
\text { tion practices. }\end{array}$ \\
\hline $\begin{array}{l}\text { Dominant solution } \\
\text { design }\end{array}$ & $\begin{array}{l}\text { Natural selection for desired } \\
\text { traits }\end{array}$ & $\begin{array}{l}\text { Marker assisted } \\
\text { selection (DNA } \\
\text { based) of target } \\
\text { genes. Transgenic or } \\
\text { non-transgenic } \\
\text { methods of plant } \\
\text { breeding }\end{array}$ & $\begin{array}{l}\text { Self-regenerative or eco- } \\
\text { friendly models of solution } \\
\text { design }\end{array}$ \\
\hline Selected principles & $\begin{array}{l}\text { Principles of Mendelian } \\
\text { genetics, and principles of } \\
\text { traditional plant sciences }\end{array}$ & $\begin{array}{l}\text { Principles of genetic } \\
\text { engineering and } \\
\text { molecular biology }\end{array}$ & $\begin{array}{l}\text { Principles of Agro Ecological } \\
\text { sciences }\end{array}$ \\
\hline $\begin{array}{l}\text { Area of scientific } \\
\text { enquiry }\end{array}$ & $\begin{array}{l}\text { Plant Sciences (Plant biology, } \\
\text { plant physiology, botany, } \\
\text { entomology), Chemistry, Soil } \\
\text { sciences }\end{array}$ & $\begin{array}{l}\text { Modern biotechnol- } \\
\text { ogy (micro-biology, } \\
\text { molecular biology, } \\
\text { bio-chemistry, } \\
\text { genetic engineering) } \\
\text { +plant Sciences }\end{array}$ & $\begin{array}{l}\text { Agro-ecological and envi- } \\
\text { ronmental sciences }\end{array}$ \\
\hline
\end{tabular}

As Table 3.1 indicates for the problem of low yields, the areas of scientific enquiry, selected principles of science and their dominant solution design differ between the paradigms. There are differences in the solution delivery platform as well. Although the areas of scientific enquiry and the selected principles overlap for green revolution (conventional) and agri-biotechnology, application of the principles of molecular biology and genetic engineering indicate a radical departure from the earlier domains of traditional plant sciences. Agro-ecology on the other hand is based on the underlying principles of agronomy and ecology where the area of scientific enquiry lies in ecological sciences.

To explain further, the new plant types that are developed during the early green revolution era (late 1960s) had the capacity to respond to the application of fertilizers without lodging thereby enabling the plant to produce more grains per stalk. Subsequently the physiological and morphological characteristics of the plants were tweaked to make them suitable for agro-ecology. The morphological characteristics were redesigned painstakingly by crossing the existing cultivars with short dwarf and better yielding varieties in order to prevent the lodging thereby improving the possibility of higher yield per plant. Also making the crops respond to application of fertilizers was one of the key objectives, especially during the period of early green revolution. Crop responses to photo sensitivity, thermo sensitivity and a range of atmospheric parameters were analysed to cater improvements in resilience. In particular, care was taken to develop varieties that showed 
better germination, uniform growth characteristics and faster production cycle. A combination of these methods of plant breeding became a dominant solution design during the green revolution period. However during the later years starting 1970s the rise of biotechnology provided advanced methods and tools to carry out plant breeding with precision bringing about radical changes to the solution design.

Under the conventional paradigm solutions were searched in the areas of fundamental plant sciences such as botany, plant biology, plant physiology, plant pathology and entomology. These areas form the basis for much of the scientific endeavors in crop production technologies. Therefore some scholars view modern agricultural biotechnology paradigm as an extension of conventional paradigm and that it is just a new trajectory with the same paradigm. But this viewpoint is narrow. Advancement in molecular biology, genetic engineering and interdisciplinary fields like bio-informatics made a huge difference to the process of problem solving. For instance, plant breeding in the conventional era involved the controlled modification of genetic makeup by natural means (natural pollen transfer between male and female lines) but in modern biotech methods, although the underlying sciences by and large remained the same, solutions like molecular markers and PCR (Polymer Chain Reaction) ${ }^{3}$ based on advancements in molecular biology are strikingly different. Advanced bioinformatics tools (genome databases) and techniques for mapping and precision analysis of DNA sequences have brought in major changes to solution design. Another significant divergence in biotech era is the manipulation of genetic material by the introduction of genes from alien species into plants (via a gene gun or Agro-bacterium mediated transformation) which is an outcome of advancements in genetic engineering.

Agro ecological paradigm ${ }^{4}$ on the other hand includes eco-friendly inputs and practices, and is fundamentally different in the method of delivery of technological solutions. The solution design here is based on principles of ecological sciences. Agro-ecological paradigm is punctuated by process innovations. Coming to forms of solutions, crop residues and cattle manure serve as fertilizers, a range of biological extracts serve as insecticides, friendlier moths and other natural pest predators, pheromone traps and light traps protect the plants from pests.

\footnotetext{
${ }^{3}$ PCR is a laboratory technique used to make multiple copies of a segment of DNA. PCR is very precise and can be used to amplify, or copy, a specific DNA target from a mixture of DNA molecules. (http://www.nature.com/scitable/definition/polymerase-chain-reaction-pcr-110)

${ }^{4}$ OECD defines agro ecology as "the study of the relation between agricultural crops and environment". (https://stats.oecd.org/glossary/detail.asp?ID=81)
} 
Table 2.4 below gives an overview of the major forms of solution delivery under the paradigm classification of crop production technologies.

Table 2.4 Major platforms of solution delivery

\begin{tabular}{llll}
\hline Innovation & Green Revolution/Conventional & Biotech & Agro-ecological \\
\hline Seed/Plant variety & Yes & Yes & No \\
Complementary inputs & Yes & Yes & Yes \\
Process & Yes & No & Yes \\
\hline
\end{tabular}

Technology landscape for problem $\mathrm{p}_{\mathrm{i}}$ : For a particular problem of insect resistance $\mathrm{p}_{\mathrm{i}}$ consider the solution in the form of synthetic inputs such as a pesticide, $t_{\mathrm{i}}$ based on principles of bio-chemistry $s_{\text {pi1 }}$. At the same time, the usage of Bt protein by genetic engineering is another solution $\mathrm{s}_{\mathrm{pi} 2}$ for problem $\mathrm{p}_{\mathrm{i}}$.

Therefore the technology landscape for the problem insect resistance is characterized by two points (pesticides, supporting principle of Bio-chemistry) $\operatorname{ing}\left(t_{p i}, s_{p i 1}\right)$, and (Bt, supporting principle of genetic engineering) $\operatorname{ing}\left(t_{p i}, s_{p i 2}\right)$.

Technology paradigm shift and technology trajectories corresponding to lemp $\mathrm{i}_{\mathrm{i}}$ : The movement from using insecticides to Bt protein can be seen as a paradigm shift in delivering a solution for insect-resistance. At the same time, the movement from principles of Bio-chemistry to principles of genetic engineering for the problem set of lower yields (which includes insect resistance, herbicide toler-

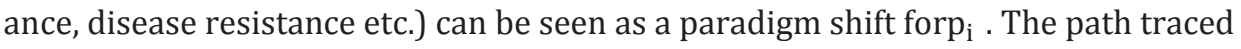
in either case is a technological trajectory.

\subsection{Illustration of search, selection and dominance of technology paradigms}

Case I: Productivity problem in India during the 1960s: By the mid-1960s, due to population growth and lagging agricultural production there was severe shortage of food in India (Parayil, 1992).

Technology search, emergence and selection through mobilization of public sector actor-networks: To address the problem of low agricultural productivity, there was a real search for the best agricultural technologies and practices to increase the production levels in cereals.

The technological breakthrough in the global technology paradigm space happened in Mexico where renowned agricultural scientist Norman Borlaug discovered the 'short legs' varieties in Maize that can support greater amounts of grain on each stalk and those that mature early. This new variety was a radical techno- 
logical breakthrough. These 'semi-dwarf' varieties clearly yielded more than the conventional varieties of the time paving the way for the creation of several 'high yielding variety' (HYV) or 'modern variety' (MV) seeds mainly in the form of open pollinated varieties (OPVs) based on this dominant solution model. OPVs produce the off springs that have the same characteristics of the parents so that farmers can replant the seeds from harvest in the next season. OPVs dominated the Indian agriculture during GR.

Through cooperation between the Indian State, the CIMMYT (International centre for the improvement of Maize and Wheat, Mexico) and Indian agricultural scientists, the high yielding dwarf varieties of wheat (a radical innovation) developed at CIMMYT were adapted to the Indian agro-ecological conditions. With GR high yielding varieties (or modern varieties or MVs), yields could be substantially increased if used with controlled doses of chemical fertilizers and water. Therefore, initially, these modern varieties in wheat and thereafter rice were introduced in select regions best endowed with fertile lands and irrigation infrastructure in India.

During in the late GR period (from 1985) hybrid varieties that could yield even better the MVs were developed. However the off springs of hybrid varieties do not have the same vigor as their parents and therefore the farmers should buy new seeds every season. Both the State and private seed firms paved the way for the development and diffusion of hybrid varieties in India during the late GR period.

Dominance: Systemic features such as reduction in market uncertainty by public procurement, supply of seed at lower prices, fertilizer subsidies, continued research investments in GR technologies, and increase in the domestic demand fueled the dominance of GR paradigm. Moreover, lack of efficient competing technology reinforced the stability of the paradigm. That is, while the economic actors in the innovation system through their strategic actions ensured the selection of GR as a preferred technology paradigm the systemic forces allowed it to become a dominant one.

Case II: Productivity problem in Indian cotton during the 1990s: By the start of the new millennium cotton yields in India were among the lowest in world. The consumption of pesticides by cotton cultivation was as high as $54 \%$ of the total pesticide consumption in the country driving the cost of cultivation higher up (Raghuram, 2002).

Technology search, emergence and selection through mobilization of private sector actor-networks: The initial technology breakthrough search in the global technology paradigm space happened in 1911, in Thuringia, Germany. There, scientists 
discovered that Bacillus thuringiensis (Bt), a bacterium acts as a natural insecticide against a local pest 'flour moth'. This led to development of a sprayable Bt pesticide first in France and later in US in 1938 and 1950 respectively. Application of Bt instead of synthetic pesticides was the starting point of a major change in the solution design for plant protection.

Another major breakthrough happened in 1982 when scientists at Monsanto isolated the cry family genes from Bt that can produce the toxin. Simultaneously elsewhere in the global technology paradigm space advanced scientific methods of analyzing and working at the level of DNA and methods of transferring genes from other species into plants came about. These were incorporated by scientists at Monsanto who successfully transferred the genes from Bt into plants. By 1996, Monsanto had commercialized Bt varieties in cotton in the US with great success.

In India a joint venture between Monsanto (US) and Mahyco (India) was initiated and it began introducing Bt cotton hybrids in the Indian market by 2002. In March 2002, the GEAC approved the commercialization of three varieties of Bt cotton hybrids (Mech-12, Mech-162 and Mech-184) developed by Mahyco in collaboration with Monsanto. This kick-started a paradigm shift in insect resistance technologies in India.

Dominance: The State (regulation) allowed for the commercialization of Bt cotton in 2002. Since then the diffusion of Bt cotton was spectacular (increased from less than $10 \%$ of the total cotton area in 2004 to more than 95\% in 2013)(James, 2013). This enthusiasm of farmers signaled not only the market success for the technology but a major transition in local seed firms' investments in agribiotechnology. Investments to develop a range of Bt crops in vegetables as well as field crops by either licensing or developing their own Bt technology are made. This way GM crops in general and Bt in particular is poised to become a dominant technology paradigm.

Other stages of the technology transitions namely economic and ecological outcomes are discussed in detail in chapter 3.

\subsection{Contribution to the literature}

While some scholars apply the evolutionary concepts of technology paradigms and trajectories to agricultural technology transitions (Parayil, 1991; Parayil, 1992; Parayil, 2003; Possas et al., 1996; Vanloqueren and Baret, 2009), an in-depth appraisal of elements of systemic technology transitions is however rare. The thesis contributes to this gap by refining the theoretical elements of a technology paradigm shift namely the evolution of problems, science base and technological solutions. The same are illustrated using the evolution of technologies in crop produc- 
tion. Moreover, for clarity, in our conceptualization, a distinction is made between the innovation system (economic actors and ecology) where actors play out their strategies and the global technology paradigm space (domain of problems, science and solutions) wherein the actual technical change occurs as a result of those strategies.

Paradigmatic classification of industrial technologies is common in innovation studies whereas its application to crop production technologies is done by only a few scholars. For instance, Parayil (2003) specifies green revolution and genetic engineering as different technological trajectories of a common technological paradigm, Vanloqueren and Baret(2009) consider agro-ecology and genetic engineering as different technological paradigms for analytical purposes. On the other hand, the thesis sees conventional and agri-biotech as two different paradigms and provides the reasons for the same.

Possas et al.(1996) argue that applying the concepts of evolutionary economics, such as technological regimes and trajectories, to agricultural innovation is much relevant as it is characterized by heterogeneous sources of innovation (public and private actors) and the diffusion process determined by agent heterogeneity (farmers choosing a new technology or practice). The thesis supports this argument and provides additional illustrations of the same in the chapters that follow. 



\section{Chapter 3. Economic and ecological outcomes of GR and GM paradigms: A systematic review}

\subsection{Starting Assumptions}

In the previous chapter, a set of definitions and theoretical constructs related to technology transitions are developed and presented. It is shown that a technology transition or a paradigm shift is characterized by economic and ecological outcomes that may form the basis of a new set of production problems. These problems necessitate a technology switch or altogether a new technological search in the global technology paradigm space. In order to empirically test this argument, in this chapter, a systematic review of impact literature of GR and GM technological transitions that marked Indian agriculture is carried out. This is followed by a meta-analysis of a set of selected impact studies. The impact literature is closely examined to verify whether the economic and ecological outcomes in both the transitions engendered any externalities that generated new set of production problems undermining the sustainability of the agricultural production.

As pointed in chapter 2 , the sustainability potential of technologies can be examined from both the economic and the ecological dimension. Studies focusing on the economic efficiency of agricultural technologies involve studying changes to yields, costs and profits. These can in turn be linked to income generation and poverty reduction via higher economic efficiency. On the other hand studies focusing on ecological outcomes involve examining the changes to the quality of resources such as soil, water and air due to production processes.

One way to evaluate both the economic and ecological impact of a new technology on the technological efficiency of the production system is through measuring the change in the Total Factor Productivity or TFP. Basically, TFP is the 'residue of effects' that account for the change in the output not caused by measurable inputs, and it can be taken as representing a measure of technical change. An increasing TFP over time implies that output is growing at least as fast as the inputs (Lynam and Herdt, 1989). A stagnant or decreasing TFP indicates that output increases are being primarily driven by increased use of inputs rather than by technological improvements. This, in turn, means that in order to sustain production levels at a given level if TFP decelerates then more inputs are needed to maintain the output levels leading to resource degradation in the case of agricultural production.

Evidently, under the above scenario the production system is not ecologically sustainable and therefore will also not be economical in the long run. In other words, a positive trend in TFP growth over a period of time indicates a sustainable production system. On the other hand, a stagnant or decelerating TFP growth indicates 
that possible i) Higher yields are being primarily driven by the growth in inputs rather than technological improvements ii) Decreasing yields per hectare are because more and more inputs are needed to maintain higher levels of output leading to resource degradation. Therefore TFP measurements can provide insights on sustainability of a production system.

\subsection{Literature on Green Revolution in India (conventional paradigm)}

The success of GR in developing countries is well documented (Pinstrup-Andersen and Hazell, 1985; Evenson and Gollin, 2003). Evenson and Gollin (2003) in their study of the impact of GR between the years 1960-2000 bring out strong evidence of the productivity increase (though uneven across crops and regions) and subsequent lowering of food prices across developing countries including India.

Since the literature on GR in India is vast, a specific corpus was identified for analysis using four sources: Econlit, Econpapers, Scopus (Economics) and Planning Commission Reports (Government of India). The search criteria applied was 'journal articles' and 'reports' with the words 'Green revolution' and 'India' appearing in 'title', 'keywords' or 'abstract'. The corpus was further filtered manually to retain only the most relevant articles that explicitly discussed the long term socioeconomic and ecological impacts of GR in India (the final corpus is presented in Appendix Table A3.1). This greatly reduced the final corpus to 20 articles for the meta-analysis. Some of the remaining articles a well as reports with agricultural statistics were referred to for discrete evidence on the economic and ecological outcomes of GR to substantiate the results of our meta-analysis.

The findings of the meta-analysis of selected impact studies of GR in India are summarized in Table 3.1. While all the studies (20) report an increase in the yield following adoption of GR varieties, few (9) explicitly measure the evolution of the TFP over time. Only 3 of the 9 studies measuring TFP identified an increasing TFP over time. Indeed, the remaining 6 studies on TFP reported a stagnant or decreasing growth in TFP from the mid-1980s implying that output growth was primarily driven by increased usage of inputs rather than by technological improvements. This signals a clear risk of resource degradation. 
Table 3.1 Focus of impact literature on Green Revolution in India

\begin{tabular}{lll}
\hline Description & Count & \% of Total \\
\hline Total number of articles considered for analysis & 20 & 100 \\
Only dealing with economic performance & 13 & 65 \\
Only dealing with ecological outcomes & $4^{*}$ & 20 \\
Discussing both & $6^{*}$ & 30 \\
Impact on yield and TFP & & 100 \\
Yield increase & 20 & NA \\
Uncertain about increase in yield or indicating decrease in yield. & 0 & 15 \\
Increasing TFP growth (i.e. acceleration of productivity) & 3 & 30 \\
Decreasing/stagnant TFP growth(in late GR period or during the & 6 & \\
1980's) & & NA \\
Generation of ecological externalities & & 35 \\
Asserting improved ecological conditions & 0 & $7^{*}$ \\
Doubtful or concerned about negative impact on ecology & & \\
\hline
\end{tabular}

Note: While some of the articles discuss the direct evidence of environmental degradation, few propose the stagnant/negative growth in TFP as being indicative of resource degradation.

Table 3.2 summarizes in detail the findings of studies on sustainability of aggregate and individual cropping systems in India by measuring the TFP.

However, the TFP estimations do not explicitly incorporate ecological externalities. Moreover, Coelli and Rao (2005) caution the interpretation of TFP measurements as they depend on the chosen methodology, output and regions, Byerlee and Murgai (2001) suggest combining both long term productivity measurements with resource quality indicators. Therefore the literature is further examined to identify other kinds of evidence on externalities of GR. 
Table 3.2 Studies on TFP estimation of crop production during GR in India

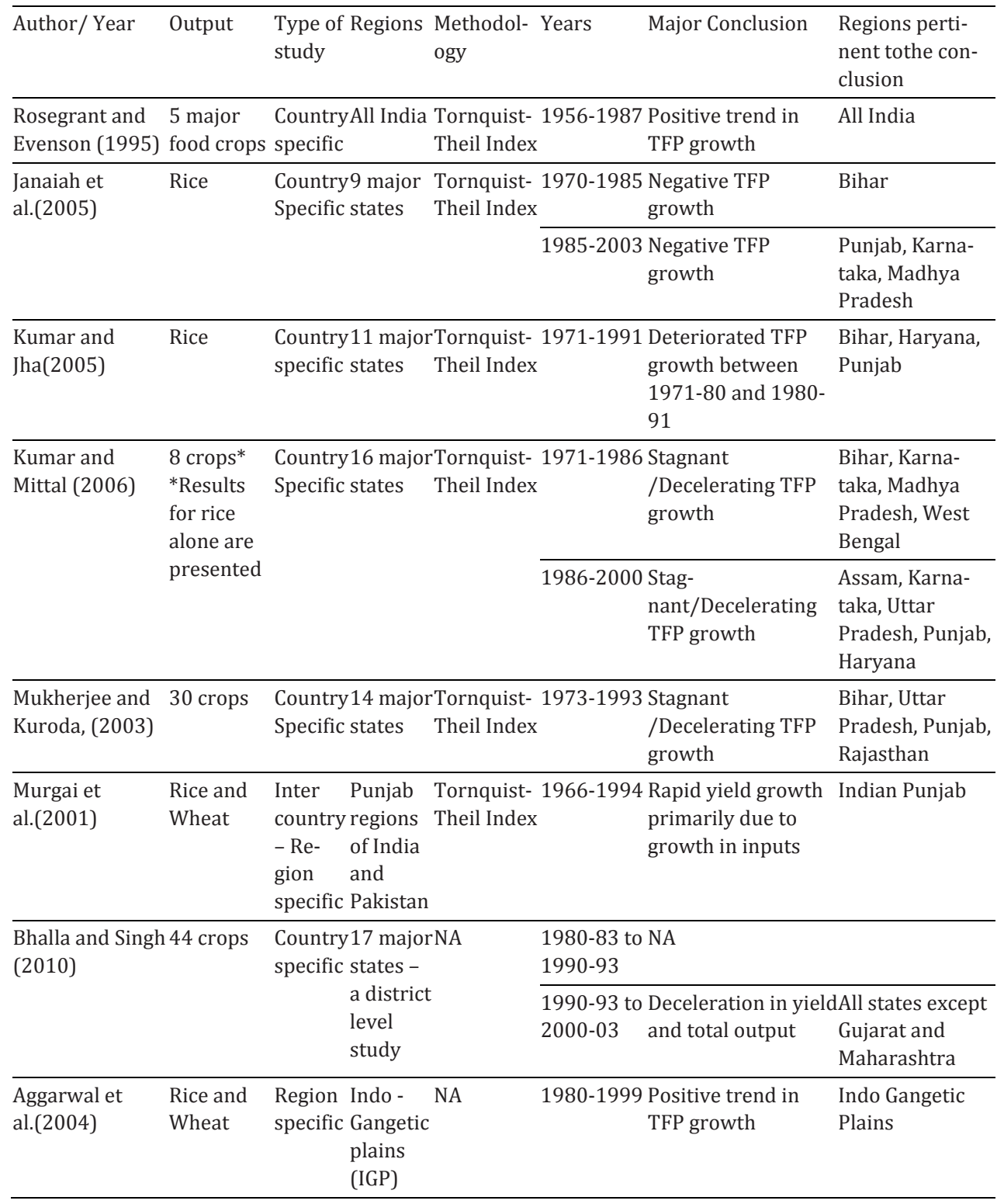


The observations on stagnant or decreasing TFP are further confirmed by statistics on the aggregate yield of rice and wheat in India depict a curve which is flattening (see Figure 3.1).

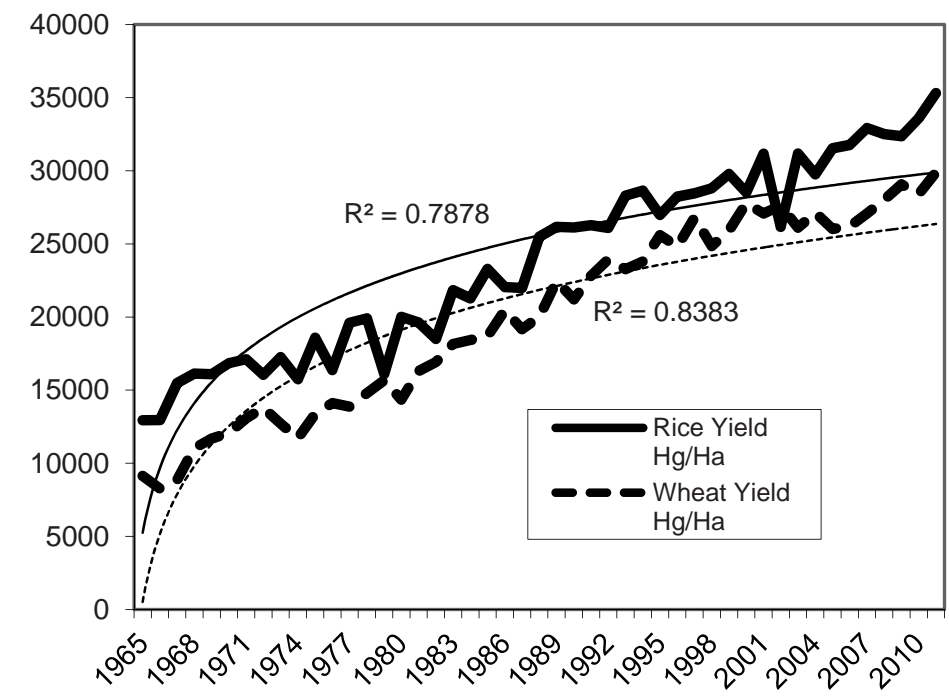

Figure 3.1 Plateauing of rice and wheat yields in India (hectograms per hectare) with a logarithmic trend line (UNFAO, 2015b)

The flattening of productivity (plateauing effect) of the two major cereals is attributed to fatigue in the development of high yielding varieties and degradation of soil and ground water resources in the high yielding regions of Punjab and Haryana(Murgai et al., 2001; Nagarajan, 2005; Dhillon et al., 2010).

Further, studies pointed out that GR increased stress on natural resources, lowering soil fertility and ground water levels especially in the high-yielding regions of Punjab and Haryana (Dhillon et al., 2010). GR technology package, by its design, calls for irrigation and application of right amounts of fertilizers in order to achieve higher yields. However optimal usage of these inputs is not practiced by farmers in many regions (Pingali, 2012; Pingali and Rosegrant, 1994). Unsurprisingly, the literature abounds with indiscriminate usage of synthetic fertilizers and ground water resources and the subsequent resource degradation.

Excess usage of chemical fertilizers increases the hard residues in the soil thereby severely affecting the intake of soil nutrients in required proportions by the plant. India stands tall globally in the consumption of chemical fertilizers following China and the US with a consumption of 17.9 metric tonnes between 2002 and 2005. Between 2006 and 2007 this figure reached 23.6 metric tonnes. Between 2002 and 
2008 the reported annual growth in the usage of Nitrogen, Phosphates and Potash as independent fertilizer nutrients in India are 6.4, 7.3 and 12.6 respectively (UNFAO, 2015b) . These levels are significantly higher in the irrigated regions as compared to rain-fed regions raising concerns of soil degradation in these regions.

Singh (2000) finds that in Haryana the expansion of agricultural productivity during GR came at the cost of severe soil and water degradation. The higher use of inputs partly stems out of lack of awareness about their negative long term effects of the overuse on soil properties. Besides this imperfect information, discounting of the future economic returns for higher returns in current time period also seems to be a problem. Less informed farmers simply think application of higher levels of inputs gives more returns. Therefore the sustainability problem is partly the technology itself and partly the implementation. In this regard, Dyson (1999) claims that the higher dependence on chemical fertilizers and consequent soil fertility loss is can cause severe cereal shortfalls in South Asia. His estimates show that by the year 2025, South Asia (of which India constitutes $70 \%$ of population) falls short of 25 million tons of cereals given the population, income levels and the current technological regime of GR varieties that dictate the dependence on chemical fertilizers, especially Nitrogen.

Water resources play a crucial role in the agricultural production and uncontrolled irrigation causes long term sustainability concerns such as ground water depletion and soil salination. GR practices also led to higher consumption of fresh water resources especially in the high yielding regions of Punjab and Haryana (Agoramoorthy, 2008). Groundwater withdrawals as a percentage of recharge between 2002 and 2008 show alarming picture in the regions of Punjab, Haryana, Delhi and Rajasthan according to Rodell et al., (2009)

Inefficient irrigation management can also lead to water logging which results in farm soil being salinized. Between 1998 and 2002 the soil salinized by irrigation in India stood around 3.3 million hectares whereas the total area waterlogged by irrigation stood at 2.4 million hectares. By 2001, about 5\% of the total area equipped for irrigation was salinized in India (UNFAO, 2015a).

GR also saw mono-culture practices of farmers. Mono-culture refers to farmers sticking to the planting of same variety every cropping season. Mono-culture of crop varieties on one hand can limit the availability of diverse genetic base for future improvements and on the other hand can cause loss of yield potential due to natural bio-physical evolution. The loss of yield potential due to natural biophysical evolution in plant varieties is explicitly dealt with in chapter 5. If the same variety is used time and again the pests and pathogens get used to the variety and as an evolutionary response grow in strength. As a consequence the variety becomes susceptible to stronger diseases and pests. 
Aggarwal et al. (2004) in their study on adaptation strategies of Indo-Gangetic plains to the emerging environmental changes indicate that the deceleration in TFP of crop production in this region was majorly due to higher usage of inputs. Further citing other studies (Pingali and Shah, 1999; Aggarwal et al., 2000; Hobbs and Morris, 1996) they state that the mono-cropping of the cereal varieties has tremendously increased the pest, disease and weed incidence in the rice-wheat system of India. ${ }^{5}$

In this regard, activists like Shiva (1989) point out that the GR intensification caused a significant loss of bio-diversity and increased the dependence of farmers on agro-chemicals, problems that the State did not address sufficiently even after the euphoria about GR had blown over.

This clearly shows that the GR diffusion witnessed the negative ecological (physical as well as biological) 'response' in the form of soil degradation, ground water depletion, and increasing incidence of pests, pathogens and weeds for popular GR varieties that undermine future production. Our assertion that a dominant technology underlying a production process can trigger ecological externalities that undermine the production process is more than realized in the case of GR transition in India. In addition, the analysis of GR transition also demonstrates that the actions of the economic actors in the innovation system could not only contribute for the emergence, selection and stability of the paradigm but also its fall out because of inefficient implementation of technologies and co-evolution of physical and biological elements to technology interventions.

\subsection{Literature on Bt cotton in India (agri-biotech paradigm)}

The government statistics on cotton in India show that the average yield has increased significantly since the introduction of Bt cotton. In 2000-01,just prior to Bt cotton introduction, the average yield in India was $190 \mathrm{~kg} / \mathrm{hectare}$ and it increased to $432 \mathrm{~kg}$ / hectare by 2007-08 with a significant jump starting in the year 2003-04, from $191 \mathrm{~kg} /$ hectare to $307 \mathrm{~kg} /$ hectare (Barik, 2010). The average cost of cultivation per hectare for cotton in India also rose significantly from INR 24,344 in 200405 to INR 48,196 in 2010-11 (Cost of Cultivation Survey, Ministry of Agriculture). On the demand side, the minimum support price for cotton as decided by the government, which is strongly correlated to the market price secured by the farmers steadily increased from INR 2010 per quintal (for long staple cotton- Ban-

\footnotetext{
5 The pests include aphis and stem borers, diseases include heliothis, false smut, sheath rot, sheath blight, spot blotch, foliar blights, head scab, and karnal bunt. Phalaris minor has become a major weed resistant to most herbicides (Aggarwal et al., 2004)
} 
ni/Brahma) in 2004-05 to INR 4000 per quintal in 2013-14 (Cotton Corporation of India statistics). These statistics show that while the average yield in cotton increased, the market price for cotton increased while the average cost also rose.

Coming to the impact of Bt cotton as apparent in the literature, a meta-analysis was carried out using a corpus extracted from Econlit, Econpapers, Scopus (Economics) and NGO reports with the search criteria being 'Bt' or 'Bacillus Thuringiensis' or 'GM or Genetically modified' and 'cotton' and 'India' appearing in the title, keywords or abstract. Again, a second round of filtering was done to retain studies that explicitly analysed the socio-economic or ecological impact of Bt cotton in India (see Appendix Table A3.2 for the list of studies included in the metaanalysis). A majority of these studies are based on cross-sectional farm level data gathered during single or multiple cropping seasons from diverse agro-ecologies of India. The remaining articles discussing other forms of discrete evidence on the impact of Bt cotton in India are also retained and referred to for insights. Also media reports are looked into for further evidence. Table 3.3 summarizes the focus of the literature corpus selected for meta-analysis.

Table 3.3 Focus of impact literature on Bt cotton in India

\begin{tabular}{lll}
\hline Description of the corpus & Count & \% of Total \\
\hline Total number of articles considered for analysis (corpus) & 35 & 100 \\
Only on economic performance & 33 & 94.3 \\
Only on ecological outcome & $1^{*}$ & 2.8 \\
On both & $4^{*}$ & 11.4 \\
Impact on Yield & 31 & 88.6 \\
Yield increase & 3 & 8.6 \\
Uncertain about increase in yield or indicating decrease in yield & 3 & \\
Generation of ecological externalities & \multicolumn{2}{|}{8.6} \\
Asserting improved ecological conditions & $3^{*}$ & 5.7 \\
Doubtful or concerned about negative impact on ecology & $2^{*}$ & \\
\hline
\end{tabular}

Note: A Majority of studies discuss positive ecological impact in terms of improved health due to reduced pesticide usage (positive effect), and negative in terms of increase in pest incidence in Bt cotton

As Table 3.3 suggests, the final corpus comprised 35 articles that explicitly discussed the long term socio-economic and ecological impacts of Bt cotton in India. While a majority of the studies (35) explicitly discussed the long term socioeconomic outcomes of Bt cotton it is also evident that only small number of studies (3) looked into ecological outcomes of Bt cotton explicitly. This illustrates the scant attention paid by a majority of impact studies on the long term ecological consequences.

The changes reported in terms of individual impact variables of Bt cotton is presented in Table 3.4. The figures indicate only minor differences and nearconsensus in the literature that the drivers for Bt at the micro-level are the in- 
creased yield and increased profit despite the rise in costs. However, within the research community debates are still ongoing on the long term socio-economic consequences, as evident from recent articles by Stone (Stone, 2012) and Herring (Herring, 2013) taking staunchly opposing viewpoints.

Table 3.4 Meta-analysis of impact literature of Bt cotton in India

\begin{tabular}{|c|c|c|c|}
\hline Variable & $\begin{array}{l}\text { Total number of articles } \\
\text { studying the variable } \\
\text { (\% of total) }\end{array}$ & $\begin{array}{l}\text { Number of articles } \\
\text { proposing that value of } \\
\text { variable has increased } \\
\text { after adoption } \\
\text { (\% of total) }\end{array}$ & $\begin{array}{l}\text { Number of articles pro- } \\
\text { posing that value of varia- } \\
\text { ble has decreased after } \\
\text { adoption } \\
\text { (\% of total) }\end{array}$ \\
\hline Profit & $27(77.14 \%)$ & $24(68.57 \%)$ & $3(8.57 \%)$ \\
\hline Cost of cultivation & $27(77.14 \%)$ & $24(68.57 \%)$ & $3(8.57 \%)$ \\
\hline Yield & $32(91.42 \%)$ & $28(80 \%)$ & $4(11.42 \%)$ \\
\hline $\begin{array}{l}\text { Pesticide sprays for } \\
\text { bollworm }\end{array}$ & $12(34.28 \%)$ & $0(0 \%)$ & $12(34.28 \%)$ \\
\hline \multirow[t]{2}{*}{ Total insecticide sprays } & $35(100 \%)$ & $4(11.42 \%)$ & $31(88.57 \%)$ \\
\hline & $\begin{array}{l}\text { Total number of articles } \\
\text { dealing with the exter- } \\
\text { nality }\end{array}$ & $\begin{array}{l}\text { Number of articles } \\
\text { proposing that exter- } \\
\text { nality has positive } \\
\text { impact } \\
\text { (\% of total) }\end{array}$ & $\begin{array}{l}\text { Number of articles pro- } \\
\text { posing that externality has } \\
\text { negative impact } \\
\text { (\% of total) }\end{array}$ \\
\hline Economic outcome. & $35(100 \%)$ & $31(88.57 \%)$ & $4(11.42 \%)$ \\
\hline $\begin{array}{l}\text { Generation of externali- } \\
\text { ties impacting ecology. }\end{array}$ & $3(8.57 \%)$ & $2(5.71 \%)$ & $1(2.85 \%)$ \\
\hline
\end{tabular}

Note: Studies based on same field data have been counted as distinct data points. While most of the studies investigate the reduction in pesticide usage only 3 studies explicitly discuss or investigate the environmental or health outcomes. Detailed findings of these studies including the changes to individual variables are elucidated in Table A3.3 of appendix.

To a large extent the impact studies show that the pesticide requirement for bollworms (primary target pests for Bt technology) reduced, yield is enhanced and profits have increased for the adopters. However, there is also overwhelming evidence that the cost of cultivation with Bt cotton hybrids has increased significantly as compared to the conventional hybrids. Yet the higher profits for the adopters are found to be driven by the increase in the yields which would have compensated for the rising costs.

In particular, the pesticide reduction effect for bollworms is shown to be positive over several years by an overwhelming majority of studies (Narayanamoorthy and Kalamkar, 2006; Barwale et al., 2004; Bennett et al., 2004; Bennett et al., 2005; Bennett et al., 2006; Gandhi and Namboodiri, 2009; Loganathan et al., 2009; Kathage and Qaim, 2012; Krishna and Qaim, 2012; Sadashivappa and Qaim, 2009; Subramanian and Qaim, 2009). 
Both socio-economic and ecological impact of Bt has been extensively discussed in the media reports. On the socio-economic front, farmer suicides in regions of Warangal, Telangana and Vidarbha, Maharashtra were linked to the total failure of Bt yields in newspapers. But, these claims were refuted by Herring (2008) through direct interviews with farmer communities, and by Gruere et al. (2008) and Gruere and Sengupta (2011) via examination of secondary data on farmer suicides, and returns to Bt cotton. Then, there were also complaints of increased economic burden on Bt adopters in the initial years due to a higher seed price. However, state level agencies set price ceilings on Bt seeds attenuating this problem (Sadashivappa and Qaim, 2009). Other temporal and spatial variations in the yields of Bt cotton reported in the newspapers time and again are attributed to failure of location specific adaptation and farmer specific characteristics such as the ways in which the new technology is implemented.

On the ecological front, death of livestock after eating Bt cotton residues was reported in the newspapers (Parsai, 2006). However the state and central agencies for livestock after looking into the issue affirmed that the cattle deaths are likely to have been caused by pesticide residues rather than Bt toxin (Kranthi, 2012). Some claims of negative impact of Bt cotton on soil also came up. For instance, activist groups expressed concerned that adoption of Bt releases Bt toxins into the soil which could affect its chemical and biological activity. In this regard, studies by soil scientists in India proved that such effects are mainly innocuous and any negative impact can be nullified by the planting of other crops like peanut between the cotton plants (Sarkar et al., 2009; Singh et al., 2013).

Coming to the evolutionary ecological responses, while the development of resistance in the American and Spotted bollworms ${ }^{6}$ for the Bt toxin is not yet are ported problem (Kranthi, 2012), the resistance in Pink bollworms became evident. In 2009, Monsanto reported the resistance in pink bollworm for Bt toxin expressed by its Cry1Ac gene in 4 districts of Gujarat (Monsanto, 2009). Scientists from CICR (Central Institute for Cotton Research) based on their analysis of 10 year monitoring data collected from several locations in the country found that while the majority of bollworm populations are still susceptible to Bt toxin, a few populations show a drastic decrease (51-fold) in their susceptibility (Kranthi, 2012).

\footnotetext{
${ }^{6}$ The primary target pest for Bt insect -resistance technology in cotton is bollworms. There are a variety of bollworm species that feed on cotton's buds, shoots and flowers which include American bollworm, Spotted or spiny bollworm and Pink bollworms. Further, aphis, jassids, mealy bugs and white flies are also feed on cotton plants. They are popularly known as 'sucking pests' as they suck the sap out of stems and leaves of the plant.
} 
While the primary pests, namely the bollworms are being effectively destroyed by the Bt toxin, secondary pests such as mealy bugs, Jassids and aphis are emerging as a growing menace for cotton farmers (Ramanjaneyulu and Kuruganti, 2006). These pests, usually referred to as secondary pests, gain in strength as the major pests (bollworms) die out as a natural evolutionary process. This could also be because Bt technology is adapted into majority of Indian varieties of cotton using the same parent, American cotton variety 'Coker', which may be susceptible to these pests.

Finally, a hitherto unseen pest in India, a mealybug (Phenacoccus Solenopsis) started infesting Bt cotton in 2006 causing considerable damage to the crops. Phenacoccus Solenopsis (Tinsley) hitherto unseen in India has become a new menace in Punjab, Haryana, Maharashtra, Madhya Pradesh and Gujarat, although the source of this species is not yet established (Nagrare et al., 2009). This could explain to some extent why pesticide sprayings for non-bollworm pests are reported to either being maintained at the same level as for the conventional cotton or increased (Bennett et al., 2004; Kiresur and Ichangi, 2011; Krishna and Qaim, 2012).
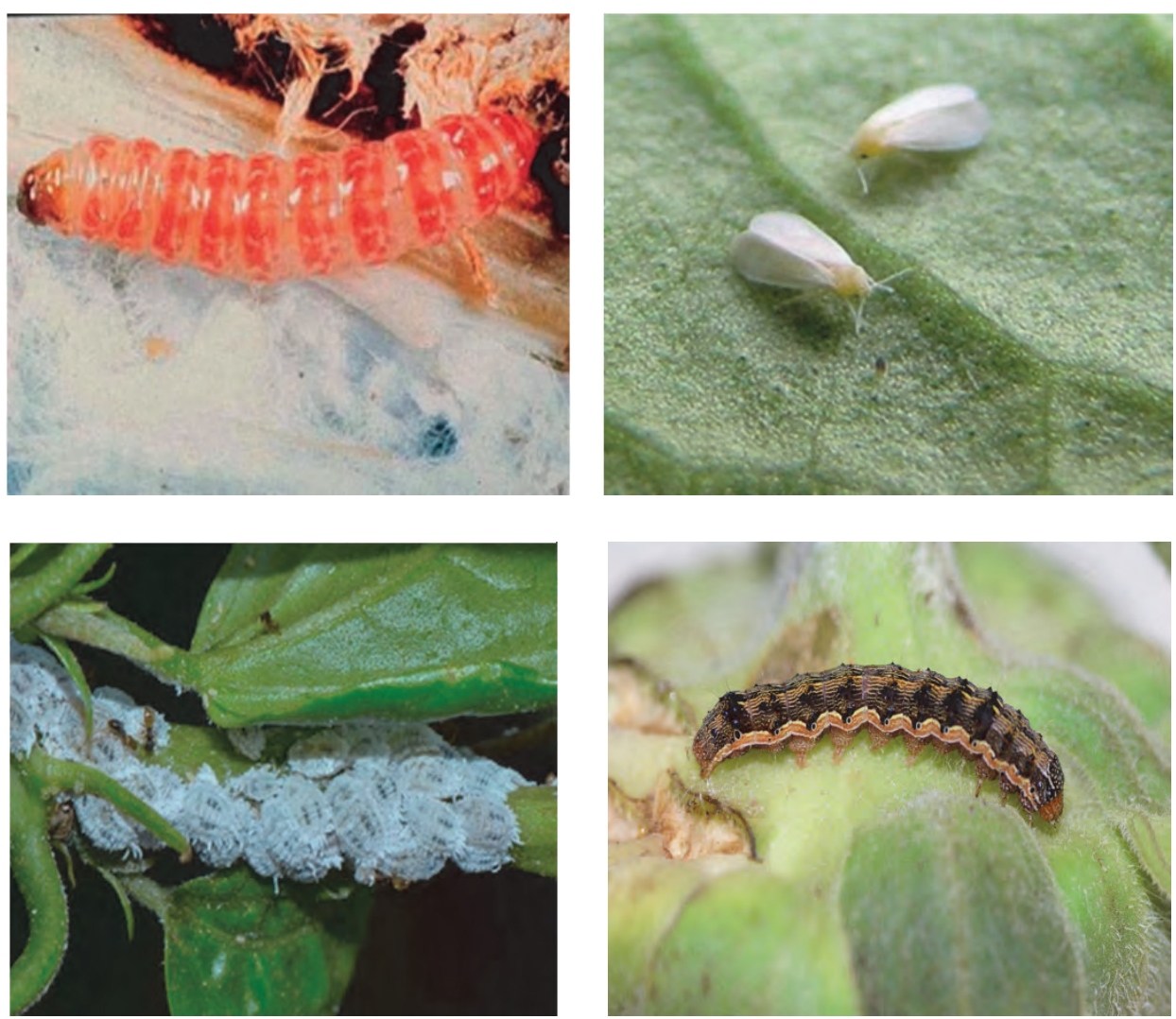

Image 3.1. Cotton Pests in India 
Top Left: American Bollworm (Helicoverpa Armigera) - the main target pest of Bt

Top Right: Pink bollworm (Pectinophora Gossypiella) developed resistance to Monsanto's Bt gene cry1Ac in 2009.

Bottom Left: Phenacoccus Solenopsis Tinsley, an exotic pest started infesting Bt cotton in India since 2006.

Bottom Right: White fly, a secondary pest in cotton whose incidence rose in Bt cotton in India.

Image Source: Indian Council of Agricultural Research - National Bureau of Agricultural Insect Resources - Crop Pest Index Database

With regard to resistance management in pests, GEAC has issued refuge guidelines for cultivation of Bt cotton. It is recommended that a refuge of non-Bt cotton around Bt-cotton fields comprising of at least $20 \%$ of the field should be planted. The non-Bt version of the crop in the vicinity of the Bt-crop ensures the survival and maintenance of susceptible insect populations. However, it is well known that a majority of Indian farmers do not implement refugia guidelines (Hanur, 2011; Singla et al., 2013). More evidence on the non-compliance of refuge and the reasons behind it are discussed in chapter 5 .

In sum, the analysis of Bt cotton transition in India also substantiates the idea that the response function of Ecology can cause new set of production problems.

\section{Appendix}

Table A3.1. Literature corpus on impact of Green Revolution in India used for meta-analysis

1. A.N. Mukherjee, Y. Kuroda, Productivity growth in Indian agriculture: is there evidence of convergence across states?, Agricultural Economics, 29 (2003) 43-53.

2. B. Dhillon, P. Kataria, P. Dhillon, National food security vis-à-vis sustainability of agriculture in high crop productivity regions, Current Science, 98 (2010) 33-36.

3. D.K. Freebairn, Did the Green Revolution Concentrate Incomes? A Quantitative Study of Research Reports, World Development, 23 (1995) 265-279.

4. G S Bhalla, G. Singh, Growth of Indian Agriculture: A District Level Study, in, Department of Economics, Punjab University, 2007.

5. G. Agoramoorthy, Can India meet the increasing food demand by 2020?, Futures, 40 (2008) 503-506.

6. K.O. JanaiahAldas, Mahabub Hossain, Is the Productivity Impact Green Revolution in Rice Vanishing? Empirical Evidence from TFP Analysis, Economic And Political Weekly, 40 (2006) 55965600 .

7. M. Prahladachar, Income distribution effects of the green revolution in India: A review of empirical evidence, World Development, 11 (1983) 927-944.

8. M.W. Rosegrant, R.E. Evenson, Total factor productivity and sources of long-term growth in Indian agriculture, EPTD discussion papers 7(1995).

9. P. Aggarwal, P. Joshi, J. Ingram, R. Gupta, Adapting food systems of the Indo-Gangetic plains to global environmental change: key information needs to improve policy formulation, Environmental Science \& Policy, 7 (2004) 487-498.

10. P. Kumar, D. Jha, Measurement of Total Factor Productivity Growth of Rice in India: Implications for Food Security and Trade, in: P.K. Joshi, Pal, S., Birthal, P.S. and Bantilan, M.C.S (Ed.) Impact of Agricultural Research: Post-Green Revolution Evidence from India NCAP New Delhi, 2005, pp. 25.

11. P. Kumar, S. Mittal, Agricultural Productivity Trends in India: Sustainability Issues, Agricultural Economics Research Review, 19 (2006) 71-88. 
12. P. Pinstrup-Andersen, P.B.R. Hazell, The impact of the green revolution and prospects for the future, Food Reviews International, 1 (1985) 1-25.

13. P.L. Pingali, Green Revolution: Impacts, limits, and the path ahead, Proceedings of the National Academy of Sciences, 109 (2012) 12302-12308.

14. P.L. Pingali, M.W. Rosegrant, Confronting the environmental consequences of the Green Revolution in Asia, EPTD discussion papers, 2 (1994).

15. R. Murgai, M. Ali, D. Byerlee, Productivity growth and sustainability in post-Green Revolution agriculture: the case of the Indian and Pakistan Punjabs, The World Bank Research Observer, 16 (2001) 199-218.

16. R. Murgai, The Green Revolution and the productivity paradox: evidence from the Indian Punjab, Agricultural Economics, 1 (2001).

17. R.B. Singh, Environmental consequences of agricultural development: a case study from the Green Revolution state of Haryana, India, Agriculture, Ecosystems \& Environment, 82 (2000) 97-103.

18. R.E. Evenson, D. Gollin, Assessing the impact of the green revolution, 1960 to 2000, Science, 300 (2003) 758-762.

19. T.J. Coelli, D.S.P. Rao, Total factor productivity growth in agriculture: a Malmquist index analysis of 93 countries, 1980-2000, Agricultural Economics, 32 (2005) 115-134.

20. V. Shiva, The Violence of The Green Revolution - Ecological Degradation and Political Conflict in Punjab, Natraj publisher, Dehra Dun, 1989.

\section{Table A3.2 Literature corpus on impact of Bt cotton in India used for meta-analysis}

21. C.A. Rama Rao, M.S. Srinivasa Rao, P. Naraiah, B. Malathi, R. Y.V.R, Profitability of cotton on a pest management continuum in Guntur district of Andhra Pradesh, Agricultural Economics Research Review, 20 (2007) 273-282.

22. D. Pemsl, H. Waibel, J. Orphal, A methodology to assess the profitability of Bt-cotton: Case study results from the state of Karnataka, India, Crop Protection, 23 (2004) 1249-1257.

23. G. Naik, An analysis of socio-economic impact of Bt technology on Indian cotton farmers, Centre for Management in Agriculture, Indian Institute of Management, Ahmedabad, India, (2001) 19.

24. G. Naik, M. Qaim, A. Subramanian, D. Zilberman, Bt cotton controversy: Some paradoxes explained, Economic and Political Weekly, (2005) 1514-1517.

25. G.P. Gruere, Y. Sun, Measuring the Contribution of Bt Cotton Adoption to India 's Cotton Yields Leap, IFPRI Discussion Paper, (2012).

26. H.R. Visawadia, A.M. Fadadu, V.D. Tarpara, A Comparative Analysis of Production and Marketing of Bt Cotton and Hybrid Cotton in Saurashtra Region of Gujarat State, Agricultural Economics Research Review, 19 (2006) 293-300.

27. J. Kathage, M. Qaim, Economic impacts and impact dynamics of Bt (Bacillus thuringiensis) cotton in India, Proceedings of the National Academy of Sciences, 109 (2012) 11652-11656.

28. M. Bennett, U. Kambhampati, S. Morse, Y. Ismael, Farm-Level Economic Performance of Genetically Modified Cotton in Maharashtra, Review of Agricultural Economics, 28 (2004) 59-71.

29. M. Lalitha, P.P. Dash, K.N. KrishnaKumar, A comparative assessment of BT and non-BT cotton cultivation on farmers livelihood in Andhra Pradesh, Journal of Biosciences Research, 2 (2011) 99-111.

30. M. Qaim, A. Subramanian, G. Naik, D. Zilberman, Adoption of Bt Cotton and Impact Variability: Insights from India, Review of Agricultural Economics, 28 (2006) 48-58.

31. M. Qaim, D. Zilberman, Yield effects of genetically modified crops in developing countries, Science, 299 (2003) 900-902.

32. M. Swaminathan, V. Rawal, Are there benefits from the cultivation of Bt cotton? A comment based on data from a Vidarbha village, Review of Agrarian Studies (RAS), 1 (2011) 101-124.

33. N. Ramgopal, Economics of Bt cotton vis-à-vis traditional cotton varieties: Study in Andhra Pradesh, in, Agro-Economic Research Centre, Andhra University, Andhra Pradesh, 2006.

34. Narayanamoorthy, S.S. Kalamkar, Is Bt cotton cultivation economically viable for Indian farm- 
ers? An empirical analysis, Economic and Political Weekly, (2006) 2716-2724.

35. O.M. Bambawale, O.P. Sarma, A. Singh, B. B.B, L. R.C, D. A, K. V, T. R.K, R. K.S, P. N.R, P. V.M, Performance of Bt cotton (MECH-162) under Integrated Pest Management in farmers' participatory field trial in Nanded district, Central India, Current Science, 86 (2004) 1628-1633.

36. P. Mal, A. Manjunatha, S. Bauer, M.N. Ahmed, Technical efficiency and environmental impact of Bt cotton and non-Bt cotton in North India, Agbioforum, 14 (2011) 164-170.

37. P. Mal, K.K. Reddy, M.A. Venkataronappa, S. Bauer, Economic Profitability and Adoption of Bt Cotton and non-Bt Cotton in North India, in: Conference on International Research on Food Security, Natural Resource Management and Rural Development 2010.

38. P. Ramasundaram, S. Vennila, R. Ingle, Bt cotton performance and constraints in central India, Outlook on Agriculture, 36 (2007) 175-180.

39. P. Sadashivappa, M. Qaim, Bt cotton in India: development of benefits and the role of government seed price interventions, Agbioforum, 12 (2009) 172-183.

40. Qayum, K. Sakkhari, Bt cotton in Andhra Pradesh - A three-year assessment. The first ever sustained independent scientific study of Bt cotton in India, in: Deccan Development Society, Deccan Development Society, 2006.

41. R. Bennett, U. Kambhampati, S. Morse, Y. Ismael, Farm-level economic performance of genetically modified cotton in Maharashtra, India, Applied Economic Perspectives and Policy, 28 (2006) 59-71.

42. R. Bennett, Y. Ismael, S. Morse, Explaining contradictory evidence regarding impacts of genetically modified crops in developing countries. Varietal performance of transgenic cotton in India, Journal of Agricultural Science-London, 143 (2005) 35-42.

43. R. Loganathan, R. Balasubramanian, K. Mani, S. Gurunathan, Productivity and Profitability Impact of Genetically Modified Crops - An Economic Analysis of Bt Cotton Cultivation in Tamil Nadu, Agricultural Economics Research Review, 22 (2009) 331-340.

44. R. Peshin, A.K. Dhawan, K. Vatta, Attributes and socio-economic dynamics of adopting Bt cotton, Economic and Political Weekly, 42 (2007) 73-80.

45. R.B. Barwale, V.R. Gadwal, U. Zehr, Prospects for Bt cotton technology in India, AgBioforum, 7 (2004) 23-26.

46. R.J. Herring, C.R. N, On the 'failure of Bt cotton' Analysing a Decade of Experience, Economic and Political Weekly, XLVII (2012) 45-54.

47. S. Kouser, M. Qaim, Impact of Bt cotton on pesticide poisoning in smallholder agriculture: A panel data analysis, Ecological Economics, 70 (2011) 2105-2113.

48. S. Morse, R. Bennett, Y. Ismael, Inequality and GM crops: a case-study of Bt cotton in India, Agbioforum, 10 (2007) `44-50.

49. S. Sahai, S. Rahman, Performance of Bt cotton: Data from first commercial crop, Economic and Political Weekly, (2003) 3139-3141.

50. S. Sahai, S. Rehman, Bt-Cotton performance 2003-2004: fields swamped with illegal variants, Economic and Political Weekly, 39 (2004) 2673-2674.

51. Subramanian, M. Qaim, Village-wide effects of agricultural biotechnology: The case of Bt cotton in India, World Development, 37 (2009) 256-267.

52. V. Shiva, A. Jafri, Failure of GMOs in India (Synthesis/Regeneration, 33/Winter), in: New Delhi, India: Research Foundation for Science, Technology and Ecology, 2004.

53. V.P. Gandhi, N. Namboodiri, Economics of Bt cotton vis-a-vis non-Bt cotton in India:A study of four major cotton growing states, in, Centre for Management in Agriculture, Indian Institute of Management Ahmedabad, 2009.

54. V.R. Kiresur, M. Ichangi, Socio-Economic Impact of Bt Cotton - A Case Study of Karnataka, Agricultural Economics Research Review, 24 (2011) 67-81.

55. V.V. Krishna, M. Qaim, Bt cotton and sustainability of pesticide reductions in India, Agricultural Systems, 107 (2012) 47-55. 
Table A3.3 Detailed findings from Bt cotton impact literature in India

\begin{tabular}{|c|c|c|c|c|c|c|}
\hline Author/s & $\begin{array}{l}\text { Years/Cr } \\
\text { opping } \\
\text { Season } \\
\text { of study }\end{array}$ & $\begin{array}{l}\text { Reduction in } \\
\text { number of } \\
\text { pesticide } \\
\text { sprays for } \\
\text { Boll- } \\
\text { worm/Quant } \\
\text { ity/ Costs }\end{array}$ & $\begin{array}{l}\text { Reduction in total- } \\
\text { pesticide usage } \\
\text { sprays/Quantity/Co } \\
\text { sts }\end{array}$ & $\begin{array}{l}\text { Change in } \\
\text { yields }\end{array}$ & $\begin{array}{l}\text { Change in } \\
\text { Cost of } \\
\text { cultiva- } \\
\text { tion }\end{array}$ & $\begin{array}{l}\text { Change in net } \\
\text { profits }\end{array}$ \\
\hline $\begin{array}{l}\text { Bambawale et al., } \\
2004 \text { ** }\end{array}$ & $\begin{array}{l}2002 \\
\text { and } \\
2003\end{array}$ & NA & Total Costs: $29.41 \%$ & $29 \%$ & $26 \%$ & $31 \%$ \\
\hline Barwaleet al., 2004** & $\begin{array}{l}\text { Kharif } \\
\text { (July) } \\
2002\end{array}$ & NA & $\begin{array}{l}\text { Total sprays: } 1.93 \\
\text { times/Ha }\end{array}$ & $\begin{array}{l}61.13 \% / \\
\mathrm{Ha}\end{array}$ & NA & $\begin{array}{l}\text { Additional } \\
\text { income of INR } \\
18,000 / \mathrm{Ha}\end{array}$ \\
\hline Bennett et al., $2004^{*}$ & 2003 & $\begin{array}{l}\text { Bollworm } \\
\text { Spraying } \\
\text { costs: } \\
50.33 \% \\
(\mathrm{MECH}-12) \text { - } \\
75.6 \%(\mathrm{MEC} \\
\mathrm{H}-162)\end{array}$ & $\begin{array}{l}\text { Total Cost: } 26.96 \% \\
\text { (MECH-12 ), } 42.62 \\
\%(\mathrm{MECH}-162)\end{array}$ & $20-37 \%$ & $9-10 \%$ & $73 \%-132 \%$ \\
\hline Bennett et al.,2005 ** & $\begin{array}{l}2002 \\
\text { and } \\
2003\end{array}$ & $\begin{array}{l}\text { Bollworm } \\
\text { Sprays: } \\
62.5 \%- \\
77.17 \%\end{array}$ & NA & $45-63 \%$ & $2 \%-15 \%$ & $49 \%-74 \%$ \\
\hline Bennett et al., $2006^{*}$ & $\begin{array}{l}2002 \\
\text { and } \\
2003\end{array}$ & $\begin{array}{l}\text { Bollworm } \\
\text { Sprays: } \\
62.5 \% \\
(2002)- \\
77.17 \% \\
(2003)\end{array}$ & NA & $45-63 \%$ & $2 \%-15 \%$ & $>50 \%$ \\
\hline $\begin{array}{l}\text { Chandrasekhar Rao } \\
\text { and Herring, } 2012 *\end{array}$ & $\begin{array}{l}2004-05 \\
2005-06\end{array}$ & NA & $\begin{array}{l}\text { Total insecticide } \\
\text { cost: }-56 \%\end{array}$ & $42.00 \%$ & $\begin{array}{l}\text { Total } \\
\text { cost: - } \\
18 \%\end{array}$ & $209.00 \%$ \\
\hline $\begin{array}{l}\text { Gandhi and Nam- } \\
\text { boodiri, } 2009 * *\end{array}$ & 2004 & NA & Total Costs: $23.98 \%$ & $31 \%$ & $6.69 \%$ & $88 \%$ \\
\hline $\begin{array}{l}\text { Guerer and Sun, } \\
2012^{* *}\end{array}$ & NA & NA & NA & $\begin{array}{l}0.29 \%- \\
0.39 \% \\
\text { per } 1 \% \\
\text { increase } \\
\text { in adop- } \\
\text { tion rate }\end{array}$ & NA & NA \\
\hline Lalitha et al.,2011** & 2011 & NA & $\begin{array}{l}\text { Total pesticide Cost: } \\
33 \% / \text { ha }\end{array}$ & $100 \% /$ ha & $100 \% /$ ha & $128.57 \% /$ ha \\
\hline $\begin{array}{l}\text { Loganathan R et } \\
\text { al.,2009** }\end{array}$ & 2004-05 & NA & Total Cost:82.3\% & $64 \%$ & $-8.48 \%$ & $668 \%$ \\
\hline Naik, 2001 & $\begin{array}{l}\text { 1998-99, } \\
2000-01\end{array}$ & Sprays: $75 \%$ & NA & $38 \%$ & NA & $77 \%$ \\
\hline Narayanamoorthy & 2003 & & Total cost: $4.69 \%$ & $52.00 \%$ & $34.75 \%$ & $79.15 \%$ \\
\hline
\end{tabular}




\begin{tabular}{|c|c|c|c|c|c|c|}
\hline Author/s & $\begin{array}{l}\text { Years/Cr } \\
\text { opping } \\
\text { Season } \\
\text { of study }\end{array}$ & $\begin{array}{l}\text { Reduction in } \\
\text { number of } \\
\text { pesticide } \\
\text { sprays for } \\
\text { Boll- } \\
\text { worm/Quant } \\
\text { ity/ Costs }\end{array}$ & $\begin{array}{l}\text { Reduction in total- } \\
\text { pesticide usage } \\
\text { sprays/Quantity/Co } \\
\text { sts }\end{array}$ & $\begin{array}{l}\text { Change in } \\
\text { yields }\end{array}$ & $\begin{array}{l}\text { Change in } \\
\text { Cost of } \\
\text { cultiva- } \\
\text { tion }\end{array}$ & $\begin{array}{l}\text { Change in net } \\
\text { profits }\end{array}$ \\
\hline \multicolumn{7}{|l|}{$\begin{array}{l}\text { and Kalamkar, } \\
2006^{* *}\end{array}$} \\
\hline Pemsl et al.,2004** & 2002 & $\begin{array}{l}\text { Bollworm } \\
\text { Sprays: } \\
77.77 \% \\
\text { (irrigated); } \\
\text { 45.45(non- } \\
\text { irrigated) }\end{array}$ & $\begin{array}{l}\text { Total sprays: } \\
45.94 \% \text { (irrigated); } \\
\text { 17.85\% (non- } \\
\text { irrigated) }\end{array}$ & $\begin{array}{l}\text { 12.82(irri } \\
\text { gated);- } \\
1.83 \% \text { (no } \\
\text { n- } \\
\text { irrigated) }\end{array}$ & $\begin{array}{l}9.2 \% \text { (irri } \\
\text { gat- } \\
\text { ed); } 26.7 \\
\%(\text { irri- } \\
\text { gated) }\end{array}$ & $\begin{array}{l}23.61 \% \text { (gross } \\
\text { margin irrigat- } \\
\text { ed);-24.37\% } \\
\text { (non-irrigated) }\end{array}$ \\
\hline Peshin et al.,2007** & $\begin{array}{l}2004- \\
2005\end{array}$ & NA & $\begin{array}{l}\text { Insecticide applica- } \\
\text { tions:119.74\%; } \\
\text { Total cost:149.86\% } \\
\text { Insecticide use } \\
\mathrm{kg} / \mathrm{ha}: 157.19 \% \mathrm{Bt} \\
\text { cotton vsnon-Bt } \\
\text { hybrids and varie- } \\
\text { ties) }\end{array}$ & $\begin{array}{l}3.33 \% \\
\text { (Bt hy- } \\
\text { brids vs } \\
\text { other } \\
\text { hybrids) }\end{array}$ & $\begin{array}{l}-7.54 \% \\
\text { (non-Bt } \\
\text { hybrids), } \\
3.31 \% \\
\text { (non- } \\
\text { hy- } \\
\text { brids/con } \\
\text { ventional } \\
\text { varieties) }\end{array}$ & $17.90 \%$ \\
\hline Puran et al.,2010* & $2007-08$ & $\begin{array}{l}\text { INR } \\
823.01 / \text { acre }\end{array}$ & NA & Higher & $\begin{array}{l}\text { INR } \\
2253 / \text { acr } \\
\text { e }\end{array}$ & INR 5275 /a \\
\hline Kathage and Qaim * & $\begin{array}{l}2002- \\
2008\end{array}$ & NA & NA & $24 \%$ & NA & $50 \%$ \\
\hline $\begin{array}{l}\text { Krishna and Qaim, } \\
2012\end{array}$ & $\begin{array}{l}2002- \\
2008\end{array}$ & NA & $\begin{array}{l}\text { Total Sprayed quan- } \\
\text { tity: } 37 \%-52 \%\end{array}$ & NA & NA & NA \\
\hline $\begin{array}{l}\text { Sadashivappa and } \\
\text { Qaim, } 2009\end{array}$ & $\begin{array}{l}2002- \\
03,2004- \\
05,2006- \\
07\end{array}$ & NA & $\begin{array}{l}\text { Total insecticide } \\
\text { use: } 41 \%\end{array}$ & $37 \%$ & $\begin{array}{l}17 \% \\
\text { (variable } \\
\text { cost; total } \\
\text { cost sans } \\
\text { seed } \\
\text { cost) }\end{array}$ & $89.00 \%$ \\
\hline $\begin{array}{l}\text { Subramaniam and } \\
\text { Qaim, 2009* }\end{array}$ & $\begin{array}{l}2002- \\
03,2004- \\
05\end{array}$ & $\begin{array}{l}\text { Bollworm } \\
\text { pesticide } \\
\text { usage: } 63 \%\end{array}$ & $\begin{array}{l}\text { Total insecticide } \\
\text { use: } 50.5 \%\end{array}$ & $35 \%$ & NA & $89.00 \%$ \\
\hline $\begin{array}{l}\text { Qaim and Zilberman, } \\
2003^{*}\end{array}$ & 2001 & $\begin{array}{l}\text { Bollworm } \\
\text { sprays: } \\
83.1 \%\end{array}$ & Total quantity: $68 \%$ & $\begin{array}{l}80 \%- \\
87 \%\end{array}$ & NA & NA \\
\hline Naik et al., $2005^{*}$ & $2002-03$ & NA & $\begin{array}{l}\text { Total sprays: } 38.43 \% \\
\text { Total insecticide } \\
\text { quantity: } 50.35 \%\end{array}$ & $37 \%$ & $\begin{array}{l}16.84 \% \\
\text { (Variable } \\
\text { cost) }\end{array}$ & $68.9 \%$ \\
\hline $\begin{array}{l}\text { Qayum and Sakkhari, } \\
2006^{*}\end{array}$ & $\begin{array}{l}2002- \\
03,2003- \\
04,2004- \\
05\end{array}$ & NA & $\begin{array}{l}\text { Total pesticide cost: } \\
7 \%\end{array}$ & $-8.90 \%$ & $12.00 \%$ & $-57 \%$ \\
\hline
\end{tabular}




\begin{tabular}{|c|c|c|c|c|c|c|}
\hline Author/s & $\begin{array}{l}\text { Years/Cr } \\
\text { opping } \\
\text { Season } \\
\text { of study }\end{array}$ & $\begin{array}{l}\text { Reduction in } \\
\text { number of } \\
\text { pesticide } \\
\text { sprays for } \\
\text { Boll- } \\
\text { worm/Quant } \\
\text { ity/ Costs }\end{array}$ & $\begin{array}{l}\text { Reduction in total- } \\
\text { pesticide usage } \\
\text { sprays/Quantity/Co } \\
\text { sts }\end{array}$ & $\begin{array}{l}\text { Change in } \\
\text { yields }\end{array}$ & $\begin{array}{l}\text { Change in } \\
\text { Cost of } \\
\text { cultiva- } \\
\text { tion }\end{array}$ & $\begin{array}{l}\text { Change in net } \\
\text { profits }\end{array}$ \\
\hline $\begin{array}{l}\text { Rama Raoet al.,2007 } \\
* *\end{array}$ & 2004-05 & NA & $\begin{array}{l}\text { Total insecticide } \\
\text { cost:-6.56\% }\end{array}$ & $5.94 \%$ & $-2.67 \%$ & $21.61 \%$ \\
\hline Ramagopal, 2006 & 2006 & $46 \%$ & NA & $55.00 \%$ & NA & $110.00 \%$ \\
\hline $\begin{array}{l}\text { Ramasundaram et al., } \\
2007^{* *}\end{array}$ & $\begin{array}{l}\text { Two } \\
\text { year } \\
\text { period }\end{array}$ & INR $1268 /$ ha & NA & $2.1 \mathrm{q} / \mathrm{ha}$ & $\begin{array}{l}\text { INR } \\
3720 / \text { ha }\end{array}$ & INR 2674 /ha \\
\hline $\begin{array}{l}\text { Sahai and Rehman, } \\
2003^{*}\end{array}$ & 2002-03 & NA & $\begin{array}{l}\text { Total costs: Rs. } 217 \\
\text { (per acre) }\end{array}$ & $-18.20 \%$ & $\begin{array}{l}\text { Rs. } 983 \\
\text { more per } \\
\text { acre }\end{array}$ & $-48.05 \%$ \\
\hline $\begin{array}{l}\text { Sahaiand Rehman, } \\
2004^{*}\end{array}$ & $\begin{array}{l}\text { Kharif } \\
2003-04\end{array}$ & NA & $\begin{array}{l}\text { Total costs: } 14.15 \% \\
\text { (2002-03),Total } \\
\text { costs: } 7.93 \% \text { (2003- } \\
04)\end{array}$ & $-15.90 \%$ & $\begin{array}{l}20.76 \% \\
(2002- \\
03), \\
15.44 \\
(2003- \\
04)\end{array}$ & $\begin{array}{l}-64.58 \%(02- \\
03),-5 \%(03- \\
04)\end{array}$ \\
\hline $\begin{array}{l}\text { Swaminathan and } \\
\text { Rawal, } 2011 *\end{array}$ & 2007 & NA & $\begin{array}{l}\text { Total pesticide costs } \\
:-43 \% \text { (Increased) }\end{array}$ & $\begin{array}{l}\text { Gross } \\
\text { value of } \\
\text { out- } \\
\text { put:7\%- } \\
101 \%\end{array}$ & $\begin{array}{l}23 \%- \\
105 \%\end{array}$ & $-6 \% 45 \% 97 \%$ \\
\hline $\begin{array}{l}\text { Visawadia et al., } 2006 \\
*\end{array}$ & 2004 & $\begin{array}{l}\text { Costs INR - } \\
979\end{array}$ & NA & $29.00 \%$ & $12.00 \%$ & $29.52 \%$ \\
\hline $\begin{array}{l}\text { Morse and Bennette, } \\
2007^{*}\end{array}$ & $\begin{array}{l}2002- \\
2003\end{array}$ & NA & NA & $31 \%$ & NA & NA \\
\hline $\begin{array}{l}\text { Kouser and Qaim, } \\
\text { 2011* }\end{array}$ & $\begin{array}{l}2002- \\
2008\end{array}$ & NA & $50 \%$ & NA & NA & NA \\
\hline $\begin{array}{l}\text { Kiresur and Ichangi, } \\
2011 * *\end{array}$ & 2007-08 & NA & NA & $31 \%$ & NA & $151 \%$ \\
\hline
\end{tabular}

Note: year YYYY-YY represents cropping season while YYYY-YYYY represents the whole year. * indicates the changes per acre while ${ }^{* *}$ indicate changes per hectare 



\section{Chapter 4. Emergence of controversy in technology transitions}

\subsection{Technology transitions and controversies ${ }^{7}$}

Controversies are prolonged debates or strong disagreements among a group of individuals on an issue. Even if a radically new plant variety offers a potential solution to improving productivity, it may not enjoy commercial success, unless it is accepted by key stakeholders in the innovation system. This could be due to controversies, which arise whenever there is a difference of opinion between actors on the radical innovation's interference with maintenance of 'productivity', 'farmer livelihoods' and 'environmental sustainability'. For social planners, it is important to steer technology transitions in agriculture towards all the three objectives, and for this, an understanding of potential controversies is essential. However, as noted in chapter 1 , in the economics of innovation literature, we do not yet have studies that focus on the emergence of controversies in the wake of radical technological breakthroughs and the paradigm shifts that follow. While the 'why' of controversies in technology transitions can be explained as being due to, as simple as, mutually conflicting beliefs, the 'how' requires further examination at a system level. Thus, the objective of this chapter is to answer the question: how do controversies emerge during technology transitions in agriculture?

The chapter is organised as follows. Section 2 introduces the conceptual framework; section 3 contains two types of validation of the conceptual construct to answer the central question. Finally, section 4 concludes with a discussion of results.

\subsection{The framework of analysis}

Recalling the theoretical construct introduced in chapter 2, the movement from one dominant technology paradigm to another within the innovation system occurs as a part of three different kinds of activities: (i) technology search; (ii) technology selection; and (iii) technology diffusion as shown in Figure 4.1.

\footnotetext{
7 This chapter is based on the published article: Shyama Ramani, Ajay Thutupalli. 2015. Emergence of controversy in technology transitions: Green revolution and Bt cotton in India, Technological Forecasting and Social Change. http://dx.doi.org/10.1016/j.techfore.2015.06.018
} 


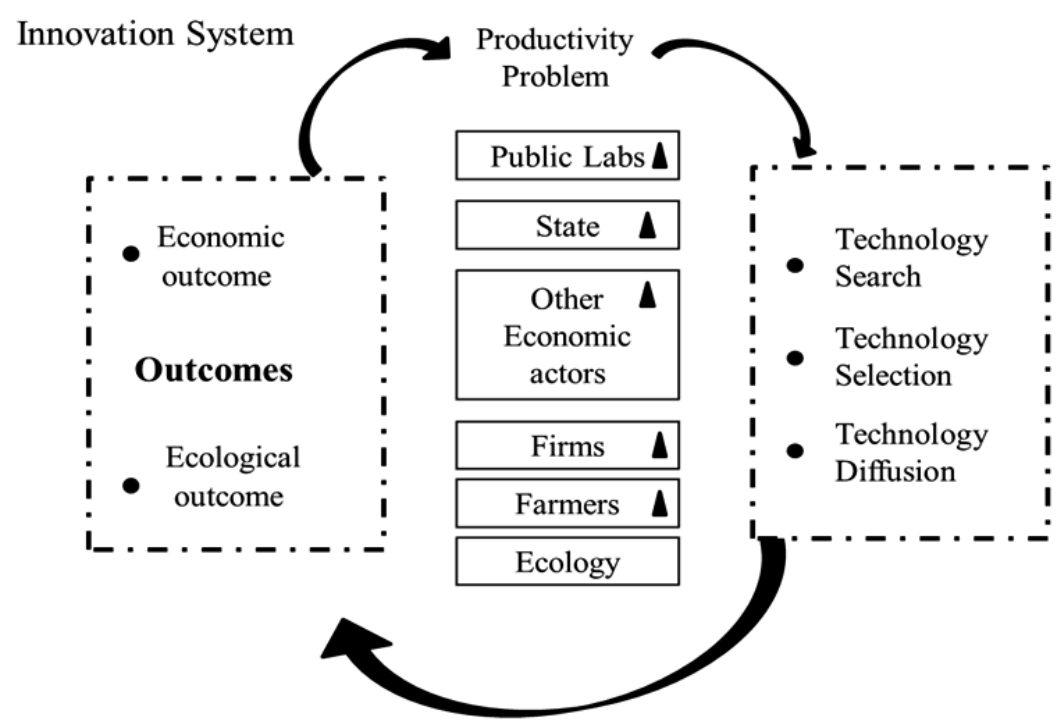

- Locus of Controversy

$\Delta \quad\{$ Belief, Strategy $\}$

Figure 4.1 Emergence of controversies in technology paradigm shifts in agriculture

A new technology is conceived in the first stage as a possible response to a productivity problem. Solutions to problems are found as a result of continuous endeavours in multiple scientific disciplines. At the same time, selection and adoption are incessantly carried out from the global supply through demand triggered by initial conditions, history, learning effects, returns to adoption, innovation characteristics etc. Eventually as multiple clusters of actors make their choices, a dominant paradigm emerges. Then as it diffuses, economic and ecological impacts are generated.

Economic actors involved in technology search, selection and diffusion choose strategies to maximize payoffs as a function of their beliefs about the possible economic and ecological impact. In contrast, Nature responds to the actions of the economic players according to biophysical laws rather than economic rationality. The belief-strategy couples of economic actor groups along with their role and power in the innovation system determines the evolution of technology transitions. Technology transitions therefore cannot be associated with any notion of consistent 'equilibrium' for they are the outcome of strategies of agents who rather than optimizing, continuously adapt to a shifting environment, while pursuing their goals. Consequently with such continuous evolution, the discourse cannot be in terms of static equilibrium, but only in terms of outcomes over time, which may or may not converge. Finally, these outcomes need not be socially optimal or even economically efficient at either a niche or sector level. 
In technology transitions, controversies stem from the differences in the forecasts of the technological trajectory and its impact on the actors in the innovation system. Controversies can arise at any stage of the technology transition if some actors anticipate losses that may not be compensated for by winners or simply by the outcomes. Differences in beliefs, information base or capabilities of the players lead to different assessments of the payoffs to each actor. The differences in perceived payoffs often pertain to the impact of negative externalities that can affect individual payoffs from adoption of a new technology. Anticipated losses may be based on popular beliefs about an uncertain future rather than established scientific insights. Therefore confrontation of scientific and perceived uncertainty in the nature of payoffs leads to controversies.

The differences in perceptions on payoffs can translate into a variety of behaviours ranging from expression of disagreement to retaliatory actions in coalitions by cluster of actors. Indeed, there could even be economic actors in the system acting against the building up of a consensus about the impact of new technology for the resulting outcome would be less favourable to them (Henry, 2011). Controversies may lead to systemic shortcomings resulting in misallocation of resources or a non-productive investment. They may also require allocation of resources for consensus building if there is no other technological solution for a given problem in the global technology paradigm space.

We will now try to answer the research question of how controversies emerge and impact technology transitions using the above framework.

\subsection{Historical reconstruction of GR and GM transition}

A two stage analysis is carried out. First, the historical reconstruction of the entry and diffusion of GR and GM cotton into India from the particular perspective of role of actors in the entry and diffusion is elucidated. Second, the findings of a Bt cotton farmers' survey on drivers of adoption and impact experiences are used to refine the construct.

\subsubsection{The Green Revolution in India}

The productivity problem: From the beginning of the 1960's, when India's population rose to about 480 million, severe food shortages began to be experienced and India began to import about $10 \%$ of its indigenous food grains production from the USA under the PL480 program (Public Law 480). It is widely acknowledged that the Lyndon Johnson administration was trying to use the PL480 program for political ends also, to put pressure on India to take a favourable view of the American involvement in the Vietnam War. Such was the food shortage that the Indian Prime Minister called upon his countrymen in 1964 to skip one meal a week so that oth- 
ers could eat (Sinha, 2001). International portrayals of India as a country with a begging bowl were far from flattering.

Technology search: Far away from India, Norman Borlaug, an American agricultural scientist arrived in Mexico in 1944 to join the CIMMYT (Centro Internacional de Mejoramiento de Maiz y Trigo) as part of a collaboration program between the Rockefeller Foundation and the agricultural ministry of Mexico. His research over the following decade led to the creation of a new semi-dwarf variety of wheat, suitable for the tropics, with 'short legs' that could support a greater amount of wheat grains on a stalk and mature early. This new variety was a radical technological breakthrough. Borlaug created it from the local Mexican varieties with the dwarfing genes sourced from a Japanese variety (Norin10). Along similar lines IR8 (or 'Miracle Rice'), a semi-dwarf rice variety was developed from its Taiwanese and Indonesian parents at IRRI (International Rice Research Institute) by the mid 1960's (Peng et al., 2010). The semi-dwarf varieties clearly yielded more than the conventional varieties of the time paving the way for the creation of several 'high yielding variety' (HYV) or 'modern variety' (MV) seeds which ushered in the GR.

Debates during the technology selection: Norman Borlaug visited India in 1963 and left $100 \mathrm{~kg}$ of seed of four wheat MVs developed at CIMMYT with the Rockefeller Foundation, which in turn began collaborating with the Ford Foundation to find Indian public laboratories to test these MVs in the field. In the Indian parliament, C Subramaniam, appointed as the Minister of Agriculture in 1964 to resolve the food crisis, unfolded a two-pronged strategy: first, search for the best technology possible in the world to grow food grains; second, change the pricing policy to provide sufficient incentives for farmers to increase production. He called upon the scientists from the IARI (Indian Agricultural Research Institute) for advice and they in turn introduced Subramaniam to Ralph Cummings of the Rockefeller Foundation, who informed him of MVs. Then, in 1965, he went to a regional FAO conference in Manila where he met scientists from the IRRI (International Rice Research Institute) and learnt of MV rice varieties.

Subramaniam decided that the Indian State (Government) must pave the way for the adoption of MVs even if it meant increasing the government's expenditure significantly. This proposal provoked an outcry from all quarters: the academics within IARI, and other politicians. The communist party was paradoxically in favour of American grain imports rather than trying out the MVs, as the USSR was also importing grain from the USA. Thus, there was a lack of consensus in the parliament and among the agricultural scientists. However, the Prime Minister himself sanctioned Subramaniam to import 23,000 tons of wheat seed from Mexico, of which 18,000 tons was from the CIMMYT for distribution in the 1965-66 cropping season. A former director of the IARI notes "Thus began the ambitious program of 
producing 25 million tons of wheat, unparalleled in the history of agriculture anywhere in the world." Dr. Borlaug later said that while CIMMYT evolved the new seed, it was the decision of India to import the seed that set a chain reaction not only in India but also in Pakistan and elsewhere." (Sinha, 2001). The wheat and rice MVs were initially not diffused throughout India, but introduced in selected states best endowed with the required agro ecological conditions and irrigation infrastructure.

Technology adoption without controversy: In the Indian case, the triumph of the GR was not due to technology alone, but to a lining up of a favourable configuration of actors and conditions favourable to the integration of the new technology. Once the decision was taken to adopt MVs, Indian scientists worked on a mission-mode as the food insecurity crisis was perceived to be a threat to national autonomy. These scientists also played a major role in the IARCs (International Agricultural Research Centres). Evenson (2002) notes that in Asia, the contribution of the IARC network to the creation of MVs from 1965 to 1988 was greatly outweighed by those of the national agricultural research systems, in terms of investment in scientific manpower and R\&D expenditures.

The State likewise greatly facilitated the diffusion of new technology by providing institutional support for credit, irrigation facilities, power, fertilizers while subsidizing MV seeds and issuing minimum support prices in the markets. In addition, a number of new supporting organizations were created for public purchase and distribution of produce. Access to farm equipment and inputs was greatly improved in the rural areas (Dorin and Landy, 2002). This reconfiguration of the innovation system was crucial to the success of the Green Revolution. There was no difference of opinion of any sort among the actors of the innovation system.

Evolution of the innovation system in the post-GR period and emergence of controversy over impact: The success of GR ensured strong government support for public sector research. There was little by way of offerings by the private sector. New enhanced plant varieties produced by public research institutions were transferred to national and state seed corporations, which produced the seeds for farmers. Fertilizers were supplied by the public sector companies or co-operatives. Nevertheless, within a decade of the diffusion of GR, claims that it was causing socio-economic inequality across landed and landless farmers began to be acknowledged (Frankel, 1971; Frankel, 1973). Activists claimed that GR was causing extensive resource degradation and environmental damage because of nonjudicious usage of inputs such as ground water, fertilizers and pesticides (Shiva, 1989; 1991). However, such controversies did not hinder the creation, adoption or diffusion of modern varieties in any way. 


\subsubsection{Economic liberalization and entry of Bt $\operatorname{cotton}^{8}$}

From the late 1980s, in India economic liberalisation was introduced in a series of major reforms that allowed both foreign multinationals and large Indian conglomerates to enter the seed sector. The embrace of market capitalism coincided with the fading away of international public organizations and the rise of private firms as the major players in the Indian agricultural innovation system. The market share of private firms in the seeds markets increased dramatically. Similarly, private companies including multinationals began to dominate the pesticides and fertilizers markets. While the role of the State as a supplier in the seed markets diminished over time, the regulatory bureaucracy involved in the post-production phase of seeds was expanded and tightened through the setup of institutions and framework for seed quality evaluation and certification (Pray et al., 2001)

The enormous success of GR also engendered a winner's curse leading the Indian agricultural research system to have near-unique focus on the creation of new modern varieties to suit the different terrains of India, to the utter neglect of new fields like biotechnology till it was forced upon them. Ramaswami and Pray (2007) also point out that scientists were not used to working in multidisciplinary teams (e.g. with scientists from different branches such as agronomy, plant breeding, plant pathology, entomology and biotechnology) required for the development of transgenes for commercial use and they were not familiar with the protocols for satisfying regulatory requirements. Moreover, as part of the reform package in 1991, public spending on agricultural research was cut, lowering the incentives for innovation creation even further. On the other hand, the investment on subsidies continued far beyond the initial phase of GR diffusion, rising steadily, so that by 2005 it was around five to six times the investment in public research (Braun et al., 2005). Thus, by the beginning of the 1990 's, grave productivity problems in agriculture, widely acknowledge ecological degradation coupled with market freedom ushered in by economic liberalisation paved the way for leading international firms in agri-biotechnology to enter the Indian innovation system.

The productivity problem: By the start of the 1990s Indian cotton yields were among the lowest in world, with high cost of cultivation, poor quality seeds and poor fibre attributes of hybrids, which deteriorated rapidly with successive pickings (Technology Mission on Cotton, Ministry of Agriculture, India). The consumption of pesticides by cotton cultivation was as high as $54 \%$ of the total pesticide

\footnotetext{
${ }^{8}$ The details on controversy surrounding Monsanto's introduction of Bt cotton in India are also discussed in Ramani and Mukherjee (2014) where they are used to explain firm strategies with respect to corporate social responsibility.
} 
consumption in the country. This high usage of pesticides was an attempt by the farmers to save the produce from the pernicious bollworms, increasing the burden on poor farmers and severely damaging the environment (Raghuram, 2002).

Technology search: In 1911 in the province of Thuringia, in Germany, a scientist discovered that a commonly occurring bacterium of the region Bacillus Thuringiensis could act as an insecticide against the local 'flour moth'. This led to the commercialization of an insecticide using this bacterium in France in 1938 and in the USA during the 1950's. Subsequent generations of the product were marketed in the form of a bacterial spray. Around 1982, scientists at Monsanto, a leading agrochemicals company then, and a world-leader in agri-biotechnology now, succeeded in isolating the genes of the Cry family responsible for the production of the toxin in the bacteria, which is reputed to provide a high degree of resistance to major insect pests such as bollworms. Then, they inserted the gene from Bacillus Thuringiensis into crops such as cotton and corn, which came to be referred to as Bt cotton and Bt corn. This constituted a radical technological breakthrough in plant production technologies. Bt cotton is a typical example of a GM plant variety producing its own insecticide, a Bt protein-based toxin that kills the pest when it ingests the plant parts.

Technology selection: Monsanto commercialized Bt cotton varieties in the USA by 1996 and began to seek to introduce it in other countries. Initial attempts to get Government approval to license the technology to Indian firms were refused, as the technology fees were deemed too high (Newell, 2007). Then Monsanto approached the biggest Indian seed company Mahyco. Mahyco was established in 1964 in Maharashtra, India, by Badrinarayan R. Barwale, a respected plant scientist who was to win the prestigious World Food Prize in 1998.Mahyco applied to the DBT (Department of Biotechnology), an agency under the aegis of the Ministry of Science and Technology to import 100 grams of Bt cotton seeds developed by Monsanto. Authorization was obtained in March 1995 and the process of crossing the American Bt cotton variety with the Indian ones began. In 1998, Monsanto obtained a $26 \%$ stake in Mahyco and it also created a joint venture, the MMB (Mahyco Monsanto Biotech company) in which each firm has a 50\% equity holding.

Controversy in technology adaptation following selection: After three years, in April 1998, Mahyco got the green signal from the DBT to carry out small trials of Bt cotton, using 100 grams of seeds in each trial plot. But, the company did not restrict itself to these small trials, drawing the attention of activists. Thus, in November 1998, the farmers group KRRS (Karnataka Rajya Raitha Sangha) burnt crops under field trials. In January, 1999, a case challenging the legality of the field trials 
authorized by the DBT was filed by well-known activist Vandana Shiva in the Supreme Court.

In July 2000, DBT granted permission to Mahyco to conduct large-scale field trials including seed production at 40 sites in six major cotton growing states with the results to be monitored by the DBT. Nevertheless, a year later, in June 2001, the GEAC (Genetic Engineering Approval Committee of the Ministry of Environment insisted that field trials of Bt cotton be extended by another year and that largescale field trials on 100 hectares be conducted again in 7 states to establish their safety. These field trials were also to be monitored by the ICAR (Indian Council of Agricultural Research). Thus the commercialization of Bt cotton was delayed by an additional year of field testing due to protests from activists such as Vandana Shiva, Nanjundaswamy (KRRS) and NGOs like Gene Campaign and Green Peace-India.

Controversy in technology adoption: While the deliberations on the safety of Bt cotton were going on, in 2001, a bollworm infestation swept through the state of Gujarat, but in some zones the cotton crop was unaffected raising suspicions. MMB filed a complaint to GEAC of industrial misconduct by a local seed firm, whereby Bt cotton seeds had been diffused and planted at a time when commercialization had not been approved in India. Navbharat Seeds, the company selling the illegal variety claimed that their hybrids were developed from insect resistant plants carefully chosen from a bollworm infested field. MMB could not press charges against Navbharat Seeds for its Bt-gene was not patent protected in India (Jayaraman, 2001a). Moreover, though GEAC immediately threatened to burn the cotton fields grown with Navbharat Seeds, nothing could be done because of farmer protests.

A year later, in March 2002, the GEAC approved the commercialization of three varieties of insect-resistant Bt cotton hybrids (Mech-12 Bt, Mech-162 Bt and Mech$184 \mathrm{Bt}$, under the brand name Bollgard $囚$ ) in the central and southern cotton growing zones for the 2002-03 growing season. Authorization for commercialization was granted for the period April 2002 to March 2005 under the condition that any farmer using Bt cotton plants refuge zones with non-Bt Cotton covering at least $20 \%$ of the cultivated land. The refuge was to act as a barrier to pollen spread and prevent the development of insect resistance. Second, Mahyco had to submit the data on the field trials every year to the GEAC. In May 2005 the GEAC permitted the commercialization of six more Bt cotton hybrids of MMB for the Northern states (Jayaraman, 2000; Jayaraman, 2001b; Jayaraman, 2001a; Jayaraman, 2003; Jayaraman et al., 2005).

Further controversy in diffusion: There are regular reports in the media about four types of problems. First, in markets, seed quality is not being controlled. Since 2002 an illegal market for Bt cotton seeds, i.e. seeds which have not been validated 
by the Indian biosafety regulatory system before entering the market, has grown steadily. Demand for illegal seeds is high due to their confirmed ability to resist bollworm and their low price (Jayaraman, 2004). The market for unauthorized seeds is also supported by the development of new varieties created by local farming ingenuity and by informal social networks between farmers based on trust, though their quality is affirmed to be lower than that of the legal seeds (Morse et al., 2005). Second, a high degree of variance in returns to Bt cotton is claimed to be increasing farmer indebtedness. Third, negative externalities in the form of an increased incidence of secondary pests and resistance build-up in target pests is noted (Shiva and Jafri, 2004; Qayum and Sakkhari, 2006; Ramanjaneyulu and Kuruganti, 2006). Lastly,death of livestock through eating Bt cotton residues are reported in newspapers highlighting health risks (Visawadia et al., 2006).

Moratorium on GM food crops: In 2009, Mahyco in collaboration with Monsanto applied for authorization to bring out a genetically modified vegetable variety, Bt brinjal (Solanummelongena also known as eggplant) into the Indian market. However, after this was granted by GEAC, there were protests from civil society groups and anti-GM activists. In response, in 2010, the Ministry of Environment imposed an indefinite moratorium on the cultivation of Bt brinjal (Forests, 2010). Further, the Ministry initiated a series of public consultations and commissioned two studies to make an informed decision on the future GM crops. First, the Parliamentary Standing Committee Reports on GM Crops (Acharia, 2012; Acharia, 2014) opined that the benefits of Bt cotton had not trickled down well to poor farmers and the state actors including ministries and the regulatory body are simply not ready for future GM crops. Second, the Supreme Court appointed a 'Technical Expert Committee' to review the existing regulatory procedures for reducing the risks associated to GM crops (Technical Expert Committee on GM crops interim report, 2012). In July 2013, its final report stated that unless the gaps in India's regulatory system could be addressed, field trials of GM crops and the commercialization of Bt Brinjal was not advisable (Technical Expert Committee on GM crops final report, 2013) .

Lifting of moratorium on GM food crops: In 2014, a new neo-liberal government favoring further economic liberalisation was elected into power in India. The new Minister of Environment proclaimed in the Parliament that GM crop research is in the national interest (PTI, 2014). Thus, in July 2014 GEAC cleared the approval of field trials for a range of food crops including rice, mustard, cotton, chickpea and brinjal (Menon, 2014)

This completes the historical reconstruction of the diffusion of GR and GM in India from the perspective of controversies. 
The technology transition from the perspective of controversies therefore was unique in each of the cases while some of the features were common and some distinctive. The points of similarity were that the technology search did not pose a problem in either in GR or Bt cotton, as both of them were essentially developed outside of India, but in both the core of controversy is centred around the risks posed by ecological uncertainties. On the other hand, the controversy was more heated, more frequent, and more prolonged in the case of Bt. This could be because of three reasons. It is more imperative for society to sustain productivity in food crops that feed citizens than in cash crops and hence controversies concerning the former are likely to be resolved faster. Further, the uncertainty associated with possible ecological externalities in the long run is greater with Bt. Finally, the number and variety of players involved in the controversy in Bt were greater than in GR, simply as a consequence of the evolution of the Indian innovation system. To sum up, the case studies support our theoretical construct and further refine it as follows.

Results 1: At the systemic level, controversies can be triggered in any of the stages of a technology transition.

Result 2: In particular, in the agricultural innovation system, the ecological outcomes rather than economic outcomes are likely to be stronger focal points of controversy.

\subsection{Farmer survey: controversy over outcomes in Bt cotton}

In order to gain some insight on the outcomes as drivers of Bt cotton diffusion, we use the primary data from the survey of 127 farmers collected between November 2011 and April 2012 in the state of Andhra Pradesh (after 2 June2014, Andhra Pradesh and Telangana). Adequate representation was ensured in sample in terms of diversity in farm resources, farmer backgrounds and agro-ecology. The details of the survey are presented in detail in chapter 5 . The surveyed farmers were those who had switched to Bt cotton hybrids since it had been made available in their local markets and had continued using Bt cotton. Thus, they could compare the changes in key economic and ecological variables for Bt vis-à-vis conventional cotton.

One of the questions to the farmers was: Why are you continuing to use Bt cotton? The farmers had to rank four options and the results are shown in Table 4.2. 
Table 4.2 Ranking of the reasons for continued use of Bt cotton

\begin{tabular}{|c|c|c|c|c|}
\hline Importance scale & $\begin{array}{l}\text { Non-availability of } \\
\text { non-Bt in the market } \\
\text { (\% of total) }\end{array}$ & $\begin{array}{l}\text { Perceived Higher } \\
\text { Profits (\% of total) }\end{array}$ & $\begin{array}{l}\text { Imitation }(\% \text { of } \\
\text { total) }\end{array}$ & $\begin{array}{l}\text { Ecological reasons } \\
\text { (\% of total) }\end{array}$ \\
\hline $\begin{array}{l}\text { Rank } 1 \text { (Most im- } \\
\text { portant factor) }\end{array}$ & $0(0 \%)$ & $53(89.83 \%)$ & $2(3.39 \%)$ & $8(13.56 \%)$ \\
\hline Rank 2 & $5(8.47 \%)$ & $5(8.47 \%)$ & $46(77.97 \%)$ & $0(0 \%)$ \\
\hline Rank 3 & $6(10.17 \%)$ & $1(1.69 \%)$ & $5(8.47 \%)$ & $5(8.47 \%)$ \\
\hline Rank 4 & $0(0 \%)$ & $0(0 \%)$ & $1(1.69 \%)$ & $0(0 \%)$ \\
\hline Irrelevant & $48(81.36 \%)$ & $0(0 \%)$ & $5(8.47 \%)$ & 46 (77.97\%) \\
\hline
\end{tabular}

Note: There were 59 respondents in total for this question

As Table 4.2 indicates, there are two forces at work: perceived higher profits and a band-wagon or herding effect each reinforcing the other. The latter had also been noted by Stone et al. (Stone et al., 2014).

Second, the farmers were requested to indicate changes experienced with Bt cotton over time and their responses are presented in Table 4.3.

Table 4.3 Impact experience of Bt cotton farmers

\begin{tabular}{|c|c|c|c|c|}
\hline Economic Impact & $\begin{array}{l}\text { Total number of } \\
\text { responses }\end{array}$ & $\begin{array}{l}\text { Value of variable } \\
\text { increased after } \\
\text { adoption } \\
\text { (\% of total) }\end{array}$ & $\begin{array}{l}\text { Value of variable } \\
\text { decreased after } \\
\text { adoption } \\
\text { (\% of total) }\end{array}$ & $\begin{array}{l}\text { Impact on variable } \\
\text { unclear } \\
\text { (\% of total) }\end{array}$ \\
\hline Profit & $95(100 \%)$ & $57(60 \%)$ & $8(8.42 \%)$ & $30(31.57 \%)$ \\
\hline Cost of cultivation & $95(100 \%)$ & $67(70.52 \%)$ & $25(26.31 \%)$ & $3(3.15 \%)$ \\
\hline Yield & $95(100 \%)$ & $56(58.94 \%)$ & $8(8.42 \%)$ & $31(32.63 \%)$ \\
\hline Ecological Impact & $\begin{array}{l}\text { Total number of } \\
\text { responses }\end{array}$ & $\begin{array}{l}\text { Adoption had nega- } \\
\text { tive impact } \\
\text { (\% of total) }\end{array}$ & $\begin{array}{l}\text { Adoption had no } \\
\text { impact } \\
\text { (\% of total) }\end{array}$ & $\begin{array}{l}\text { Uncertain about } \\
\text { impact( } \% \text { of total) }\end{array}$ \\
\hline Soil Fertility & $84(100 \%)$ & $21(25 \%)$ & $52(61.90 \%)$ & $11(13.10 \%)$ \\
\hline $\begin{array}{l}\text { Yields in adjacent } \\
\text { fields/season }\end{array}$ & $84(100 \%)$ & $12(14.29 \%)$ & $64(76.19 \%)$ & $8(9.52 \%)$ \\
\hline Cattle/Animal Health & $84(100 \%)$ & $14(16.67 \%)$ & $63(75 \%)$ & $7(8.33 \%)$ \\
\hline Health of farmers & $84(100 \%)$ & 17 (20.24\%) & $58(69.05 \%)$ & $9(10.71 \%)$ \\
\hline $\begin{array}{l}\text { Pest and disease inci- } \\
\text { dence }\end{array}$ & $84(100 \%)$ & $26(30.95 \%)$ & $5160.71 \%)$ & $7(8.33 \%)$ \\
\hline
\end{tabular}

A majority of the farmers enjoyed increased profits along with increased yields even though the cost of cultivation had risen. Even within the small sample the outcomes are strikingly in line with the findings of the meta-analysis (compare 
Tables 4.1 and 4.3). A majority of farmers did not perceive much damage from their Bt cotton experience. However, a sizable population (about 31\%) think that ecological problems in terms of increased pest and disease incidence is a reality and there is a slight disagreement on parameters such as soil fertility (which cannot be linked to the new technology per se). This shows that even in a small sample of farmers, there is still uncertainty and disagreement on the externalities generated by the implementation of the technology.

This leads to a third result that not all significant differences in beliefs evolve into controversies.

Result 3: Large scale adoption can co-exist with significant differences in beliefs on the long term economic and ecological impacts of a new technology, when short run payoffs are high.

\subsection{Discussion of results}

The objective of the chapter is to analyse the anatomy and evolution of controversies that accompany technology transitions in agriculture. To this end, a theoretical construct that was proposed whereby technology transitions were represented as the continuous outcomes of games played in the agriculture innovation system is applied to GR and GM transitions in India, through historical reconstruction and a farmer survey, yielded three further refinements.

First, as Result 1 pointed out, though it is impossible to pinpoint in which phase controversy is likely to emerge in an agriculture innovation system, for any radically new technology paradigm in agriculture, the controversy is likely to be centred on the responses of Ecology which in turn can affect future economic returns (Result 2). That said each technology transition is unique. The transitions of GR and GM in India exhibited some distinctive as well as common features. Technology search did not pose a problem in either in GR or GM, because both of them were essentially developed outside of India. However, difference of opinion became evident during 'technology selection' in GR; and in both 'selection' and 'diffusion' phases in Bt. For GR, the controversy took the form of 'debates' within two communities namely members of the Parliament and the heads of scientific institutions excluding other stakeholders in the innovation system.

In the Bt cotton case, all stakeholders in the innovation system were engaged in the debate such that it had an impact on commercialization of other GM crops in the R\&D pipeline even after the enthusiastic diffusion of Bt cotton. The introduction of Bt cotton also indicated that between the stages of technology selection and technology adoption, there is another important step where controversies can arise, namely technology adaptation. Though not applicable to all sectors to this degree, 
in the case of agriculture there is a systematic need for technology adaptation to local ecological conditions. Moreover, after adoption of the new technology, there can be controversy post diffusion when the larger outcomes become evident. Consequently, in technological forecasting in agriculture, assessment of impact on social change must go beyond the diffusion stage to incorporate the long term environmental and livelihood effects via market signals as well as ecological externalities.

Second, Result 3 proposed that large scale adoption can co-exist with controversy if the short term payoffs to adopters are high enough to override long term concerns of sustainability of such payoffs. Whenever major technology breakthroughs are shrouded in uncertainty in terms of their market impact and possible externalities generated, they can give rise to a configuration of actor-communities in the innovation system in partial or total opposition to one another. With their views and actions being supported by typical micro-drivers such as resources (including knowledge, information base and beliefs), capabilities, and preferences, in the presence of real uncertainty, there is room for clusters of economic actors expressing contradictory opinions, each fabricating its own vision of uncertainty. Informational asymmetries give rise to a spectrum of beliefs. In such contexts, controversies mark the technology transition which evolves as an outcome of bargaining between actor-communities.

In the GR transition the actors providing the new technology were public sector actors. The Indian government had the greatest bargaining strength in the innovation system then and it paved the way for GR. To this the meta-analysis on GR added that the Indian government continued to support GR long after the negative consequences began to be observed. There was a consensus about the environmental damage but it was also clear that there was no viable alternative. That is why the controversy was muted.

The fact that there can often be real scientific uncertainty accompanying a new technology is amply illustrated by the airing of views on Bt cotton. Like two faces of the same coin, GM plants provoke completely opposing views from experts. The positive face points to the decrease in negative environmental externalities due to lowered pesticide usage, while the negative face refers to the possible undesirable consequences from exposure of Bt cotton to humans, cattle, and other species in the ecology. The possible risks evoked have been the production of new allergens harmful to human health (Konig et al., 2004), contamination of non-GM plants of the same species through cross-pollination by wind, insects, birds or animals resulting in non-availability of non-GM gene pool (Altieri, 2005; Paoletti and Pimentel, 1995) and resistance to the Bt toxin over time. At a zone level, disequilibrium could also be provoked in the ecology, for example, through an increase in the 
population of secondary pests or reduction in the biodiversity in terms of availability of non-GM varieties (Thies and Devare, 2007). In response to such concerns on the possible negative impacts, others point out that to date there have been no observations of any negative environmental impact that should cause concern (Shelton, 2007). However, they do not rule out the possibility of adverse events with certainty because of lack of credible long term data.

With respect to India, some claim that the risk of bio-diversity is exacerbated by the fact that more Bt cotton varieties of the same gene pool variety are being approved. Between 2005 and 2007, 130 varieties of Bt cotton, all of them containing cry 1 Ac have been approved by GEAC. By 2012 this became 236 hybrids with Bollgard I genes and 746 hybrids with Bollgard II genes (GEAC, 2013). According to some scientists, the effect of such integration of technology in new plant varieties for short-term gains coupled with random compliance with the planting of refuge makes the threat of widespread loss of biodiversity in India a real one (Jayaraman et al., 2005). However, others assert that the implications of GM insect resistant technology for the eventual evolution of pest resistance are not at all clear.

In the meantime, despite the controversy, technology adoption of GR and GM was driven by standard market variables such as expected profits and accessibility (i.e. availability in terms of quantity, geographical proximity to supply and affordability in terms of price). GR was made accessible to the farmers through public extension services and demand was supported through the provision of credit to farmers. In the case of Bt cotton, private firms made seeds available and government ceilings on prices made them affordable. The rules of the game within the innovation system were thus favourable for adoption. In addition there was there was strong inter-agent learning and imitation whereby the success of adopters fuelled further adoption. Even if environmental impact was discerned by some farmers, as long as they did not pose a significant risk to higher short term profit, the new technology was persistently used.

Finally, the study of controversies during technology transitions in agriculture also leads to a fourth result that can hold for any sector:

Result 4: The greater the complexity of the innovation system in which technology transition is embedded, the higher the likelihood of controversies.

When GR was introduced, the creation and release of new plant varieties was controlled by a set of public agencies coordinating with one another. However, with the adoption of economic liberalisation, the innovation system became more selforganised with lesser intervention from the previous dominant players. From the early GR era (late 1960s) to the Bt cotton era (from 2002 onwards) the number 
and variety of actors in the innovation system and the interactions between them increased (see Figure 4.2). Thus, the innovation system became more complex at the time of entry of Bt cotton as compared to GR. It also became more difficult for the state to control the innovation system as the public sector laboratories had bowed out as key players, to be replaced by private firms and foreign multinationals with clearly superior technological capabilities and strategies driven by market signals. Unsurprisingly, controversies increased. However, changes in the rules of the game via regulation with respect to Bt cotton failed to eliminate controversies.

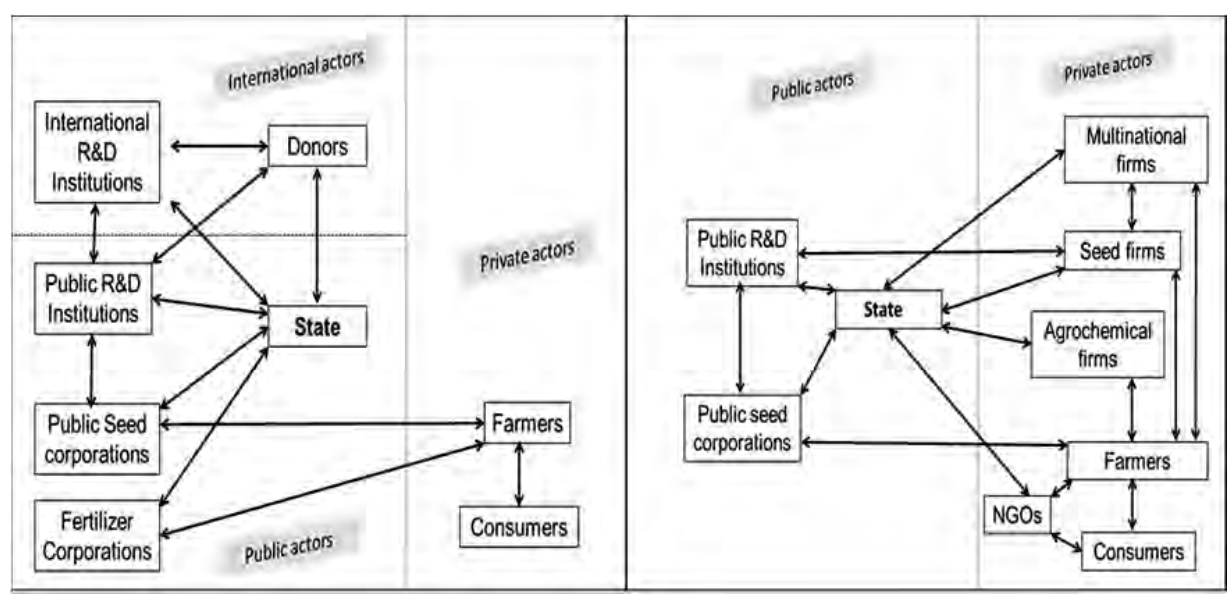

Figure 4.2 Agricultural Innovation systems in India during the GR (left) and Bt cotton (right) technology transitions

\subsection{Conclusion}

The objective of this chapter was to understand how controversies emerge during major technological transition. For answering this question the conceptual framework combining the notions of technological transitions and the actor strategies was revisited.

Though, it is widely acknowledged that it is not only the intrinsic characteristics of the innovation that determine the scale of diffusion, but also the strategic positioning of key stake-holders vis-à-vis the innovation. This was illustrated through the cases of green revolution and Bt cotton in India which showed that controversies can be triggered at diverse stages of transition. Moreover, the cases also demonstrated that in case of agriculture the controversies are more likely to be based on ecological outcomes.

The meta-analysis of Bt cotton impact literature in chapter 3 showed that a majority of the Bt cotton adopters enjoyed increased profits along with increased yields 
even though the cost of cultivation rose. The farmer survey showed that the perceived higher profits were the main reason for adoption. These results indicate that controversies can co-exist with wide-scale adoption.

Finally it is shown that in the case of emerging technologies shrouded in uncertainty, the confrontation of scientific uncertainty and perceived uncertainty lies at the foundation of controversies. Moreover the cases of GR and GM indicate that agricultural innovation systems are becoming more complex. By this we mean that the number or variety of actors, actor interactions or strategic possibilities in increasing. With greater complexity the potential for contradictory strategic positioning of actor-communities naturally becomes greater. The likelihood of controversies in an innovation system increases with a rise in anarchy, when the degree of control (or bargaining power) of the State (whose rationality and strategy follows a socially optimum outcome) decreases and clusters of actor-communities choose their actions on the basis of their private objectives, beliefs and information base. As the number of private players whose rationality is to maximize own payoffs increases, the outcome may not always be a social optimum. Then to ensure co-ordination and co-operation the rules of the game have to be changed via regulation.

To conclude, whenever major technology breakthroughs are shrouded in uncertainty in terms of their market impact and possible externalities generated, they can give rise to a configuration of actor-communities in the innovation system in partial or total opposition to one another. With their views and actions being supported by typical micro-drivers such as resources, capabilities, and preferences, there is room for clusters of economic actors to express contradictory opinions, each fabricating its own vision of uncertainty. In such contexts, controversies can mark technology transitions, which evolve as an outcome of bargaining between actor-communities. 


\section{Chapter 5. Technology transitions and sustainable adoption, a farmer's perspective}

\subsection{Technology transitions and sustainable adoption ${ }^{9}$}

This chapter deals with the question, how are sustainability concerns integrated in drivers of new technology adoption by farmers. In other words, it tackles the questions: what are the drivers of the sustainable adoption of GM plant varieties by farmers? Are their implementation practices mindful of possible externalities or long term impact of technologies?

To answer these queries, first, a model of new technology adoption in agriculture is developed that not only serves to examine the issues raised in the literature on Bt cotton, but also incorporates four intrinsic features of agriculture technology largely overlooked in innovation studies. These are the: (i) natural built-in technological obsolescence in seed varieties due to the specificities of agricultural production; (ii) generation of ecological externalities that are a part and parcel of agricultural innovation diffusion trajectories; (iii) farmer heterogeneity in terms of preferences for adoption of sustainability guidelines, and finally (iv) observance or non-observance of suggested farm management practices for agro-ecological sustainability, which will follow from the former three factors.

Second, the theoretical model is translated into a survey questionnaire and applied on a set of Bt cotton farmers. The resulting data is used to estimate empirical models of economic and ecological impact providing further insight on the ground realities of farmer behaviour and drivers of Bt adoption.

At this point, the two main limitations of the exercise must be pointed out. The survey was carried out on 127 Bt cotton farmers in the state of Andhra Pradesh between Nov 2011 and April 2012 and Telangana in India, using a semi-structured questionnaire. In other words, it represents the perceptions of a miniscule proportion of the millions of Bt cotton farmers in India, and is bound to reflect regional specificities. In addition, our primary data is limited by the bounded rationality and memory of our interviewees. However, despite these two obvious shortcomings, the study remains unique on the premise that every enquiry on the impact experience of $\mathrm{Bt}$ cotton farmers provides an important key to understanding the rationale for new technology adoption and compliance.

\footnotetext{
9 This chapter is based on the paper: Shyama Ramani, Ajay Thutupalli, Mhamed-Ali El-Aroui. 2015. Impact experiences of Bt cotton adopters in India: the role of technology obsolescence, the ecology and the farmer.
} 
The rest of the chapter is organised as follows. First, in section 5.2 a model on new technology adoption and returns to adoption in agriculture is developed. Second, in section 5.3 the survey design, empirical models and analysis are presented. Finally, in section 5.4 the results are discussed.

\subsection{New technology adoption in agriculture: a model}

In standard production functions, if an input combination is used time and again, the output is not supposed to change. While this largely holds in factory production, in agriculture even if the same input-output combination is used time after time, diminishing 'vigour' of one of the inputs - seed sets in over time, leading to diminishing returns to yield. This occurs because once a new plant type gains popularity it is adopted widely and is planted in multiple cropping seasons and suitable agro-ecologies. Over a span of years, the new plant variety becomes vulnerable to new pests and pathogens that evolve to damage it. The natural evolution of such pests and diseases eventually pulls down the yield of the new variety. This reality also calls for continual investments in seed technology research to sustain agriculture productivity. We refer to this trajectory of diminishing yield over time as its 'technology obsolescence curve'. The reality of such built-in seed technology obsolescence calls for continual investments in seed technology R\&D including the creation of new plant varieties to sustain productivity (Swanson, 2002; Peng et al., 1999; Peng et al., 2010).

In addition to the above feature, agriculture technology marks its distinction from those of manufacturing in two more ways. As illustrated by debates on $\mathrm{Bt}$, the implementation of any new production technology usually trigger externalities in the eco-system, which not only affects soil, air and water (quality) but also the health of animals and humans. In response, in order to minimize the impact of any possible negative externality, public agencies issue farm management guidelines. But, farmers can choose whether or not to implement these practices according to their preference for sustainability.

These three realities of agriculture namely: built-in fall in yield potential of a seed, generation of ecological externalities and farmer heterogeneity in terms of sustainable practices are largely overlooked in standard models. Thus, in this section, we develop a conceptual model integrating these different features.

\subsubsection{Nature of returns to new seed technology and compliance to sus- tainability guidelines}

Consider a region, where a conventional variety with a concave production func-

tion $f\left(x_{i}, \xi_{i, t}\right)$ is being cultivated by two farmers, $i=1,2$. Here $x_{i}$ represents the 
vector of endowments and other variable inputs such as seeds; and $\xi_{i, t}$ the agroecological quality at time $t$. The lower the value of $\xi_{i, t}$, the lower is the yield per unit of land. The agro-ecological condition $\xi_{i, t}$ is driven by the prior technology and compliance choices of both farmers as they jointly determine the externalities generated though each farmer is more affected by his own choices than that of the other. ${ }^{10}$

Now suppose a new type of seed, say a genetically modified Bt seed, associated with another production function $f_{b t}\left(x_{i}, \xi_{i, t}\right)$ requiring a different ratio of agrochemicals and irrigation, becomes available in the market. However, this does not change the output and input markets which remain stable with $\mathrm{p}$ as the output price and was the vector of input prices.

Public agencies issue a set of guidelines on adoption of the new technology to safeguard ecological sustainability. Compliance to sustainability guidelines involves a fixed cost that helps preserve the agro-ecology over time.

First, for simplicity, let us consider the case where both farmers have same endowments and of same quality at the start i.e. at time $t=0$. Under the given market prices and the production functions, let $x^{*}(t), x_{b t}^{*}(t)$ be the profit maximizing input combinations at time $t$ for the conventional seed technology and Bt technology without compliance. Let $\hat{x}^{*}(t), \hat{x}_{b t}^{*}(t)$ be the profit maximizing input combinations at time $t$ for the conventional seed technology and Bt technology with compliance. Correspondingly, let $\pi(t), \pi_{b t}(t), \hat{\pi}(t)$, and $\hat{\pi}_{b t}(t)$ be the profit flows over time $t$, obtained from application of the optimal input combinations $x^{*}(t), x_{b t}^{*}(t), \hat{x}^{*}(t)$ and $\hat{x}_{b t}^{*}(t)$ for a farmer. Here, $\hat{\pi}_{b t}(t), \hat{\pi}(t)$ represent the profits earned by a farmer complying from the start i.e., from $t=0$. Lastly, let compliance choice be given by $c$ which takes value 1 under compliance and 0 otherwise. Thus $\hat{\pi}_{b t}(t)=\hat{\pi}_{b t}(\mathrm{c}=1, t)$ and $\pi_{b t}(t)=\pi_{b t}(\mathrm{c}=0, t)$.

\footnotetext{
${ }^{10}$ Consider for any farmer $i$. Let the indicator of agro-ecological quality that varies as a function of the technology choice of the farmer at time $t$ be $\Delta_{i, t}$. Then for a farmer in time $t$, the agro-ecological condition is given by $\xi_{i, t}=\xi_{i, t-1}-\Delta_{i, t-1}-\partial \sum_{j \neq i} \Delta_{j, t-1}$ where $0<\partial<1$.
} 
Let the period 0 to $\hat{T}$ be the lifetime of a conventional seed with compliance, i.e. after time $\hat{T}$, its productivity reaches the minimum. Similarly, let the period from 0 to $T^{b t}$ and $\hat{T}^{b t}$ be the lifetime of the Bt seed without and with compliance. Then, sustainability guidelines ensure that returns with compliance are higher than without over the lifetime $T^{b t}$ or:

$$
\int_{t=0}^{T^{b t}} \hat{\pi}_{b t}(t) d t>\int_{t=0}^{T} \pi_{b t}(t) d t .
$$

Furthermore, for any technology, compliance lowers returns at the start, as it involves a fixed cost. Then as agro-ecology gets less damaged, it yields higher returns implying that for $\mathrm{Bt}$, there exists a time $T_{1}$ beyond which returns from compliance are higher:

$$
\pi_{b t}(t)>\hat{\pi}_{b t}(t) \text { for } t<T_{1} \text { but } \pi_{b t}(t)<\hat{\pi}_{b t}(t) \text { for } t>T_{1} .
$$

At the start, when Bt technology is introduced, let us suppose that it is a viable alternative to the conventional one with or without compliance. But, the conventional seed has been sufficiently long in use with consequent agro-ecological damage that returns to conventional seed with compliance are higher than without compliance, i.e.:

$$
\pi_{b t}(t)>\hat{\pi}(t)>\pi(t) \text { and } \hat{\pi}_{b t}(t)>\hat{\pi}(t)>\pi(t) \text { at } t=0 .
$$

Therefore, farmers observe compliance with conventional seed. Still, for all seed technologies, due to the built-in technology obsolescence of the seed and the evolution of the agro-ecological conditions of the region, yield per seed falls over time. Assuming a constant elasticity of substitution between inputs greater than zero but less than infinity, the loss per unit of land (or seed) has to be compensated by increasing other inputs. In other words, over time, to produce the same output, the farmer needs more inputs. Therefore, given unchanging input and output prices, for any fixed quantity of output, the average revenue remains constant, while the average cost increases, thereby lowering profit over time, whether or not compliance is observed. Thus, with or without compliance, the profit functions are assumed to be decreasing and strictly concave over time. 


$$
\frac{d \pi_{b t}}{d t}<0 ; \frac{d \hat{\pi}_{b t}}{d t}<0 ; \frac{d \pi_{b t}^{2}}{d t^{2}}<0 ; \frac{d \hat{\pi}_{b t}^{2}}{d t^{2}}<0 .
$$

Combining equations (2) and (4), clearly compliance slows down technology obsolescence, i.e. $\left|\frac{d \hat{\pi}_{b t}}{d t}\right| \leq\left|\frac{d \pi_{b t}}{d t}\right|$ for all $t$.

Indeed, in the post-adoption period, advantages from compliance are directly proportional to the prior time period over which compliance has been practised. This feature becomes particularly important whenever the returns from new technology without compliance fall steeply over time, below what would have been possible had compliance been observed, and perhaps even below profit from the conventional technology. For instance, consider that whenever returns without compliance $\pi_{b t}(t)$ fall below the returns with compliance $\hat{\pi}_{b t}(t)$, then by switching to 'compliance' profit seeking farmers will not do as well as those who had been complying for longer periods of time. Let $\hat{\pi}_{b t}\left(t \mid t_{\text {start }}=\tilde{t}\right)$ represents the profit of a late complier who begins adopting guidelines at time $\tilde{t}>0$. Consider two farmers, with one complying from time $\tilde{t}$ and another complying later at $\bar{t}$, then we have:

$$
\left[\hat{\pi}_{b t}(t)-\pi_{b t}(t)\right]>0 \Rightarrow\left[\hat{\pi}_{b t}\left(t \mid t_{\text {start }}=\tilde{t}\right)\right]>\left[\hat{\pi}_{b t}\left(t \mid t_{\text {start }}=\bar{t}\right)\right] \text { for } \tilde{t}<\bar{t} \leq t
$$

Finally, we suppose that if the new technology engenders significant negative externalities such that its yields fall to those of the conventional technology then with compliance this would occur at a later time; or:

$$
\text { At a time } T^{*}, \pi_{b t}\left(T^{*}\right)=\hat{\pi}\left(T^{*}\right) \Rightarrow \hat{\pi}_{b t}\left(T^{*}\right)>\pi_{b t}\left(T^{*}\right) \text {. }
$$

There are three possible scenarios of profit trajectories that can satisfy equations (1)-(6). Under scenario 1, the profit trajectories from Bt with or without compliance, strictly dominate the one from the conventional technology at every point of time as in Figure 5.1. 


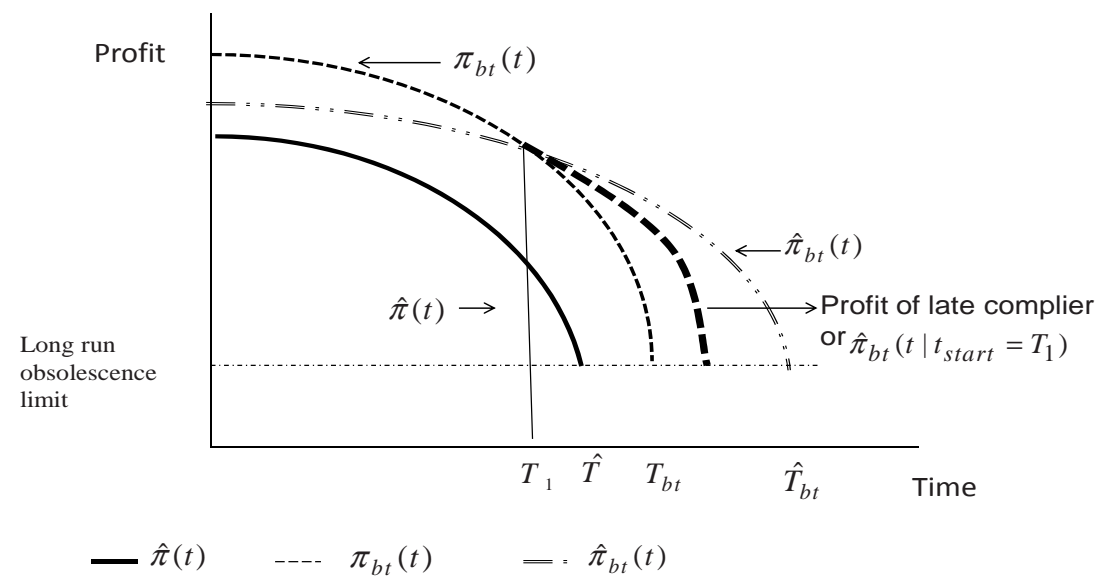

Figure 5.1Strict profit dominance of Bt over conventional type over the lifetime

Under scenario 2, for a limited time the Bt profit trajectories with or without compliance, strictly dominate that of the conventional technology and thereafter they fall below. For instance, consider profits evolution as in Figure 5.2. By equation (5), profit of the late complier is below that of farmers who comply from the start and by equation (6) the Bt profit curve with compliance cuts the conventional seed profit curve later than the Bt profit curve without compliance.

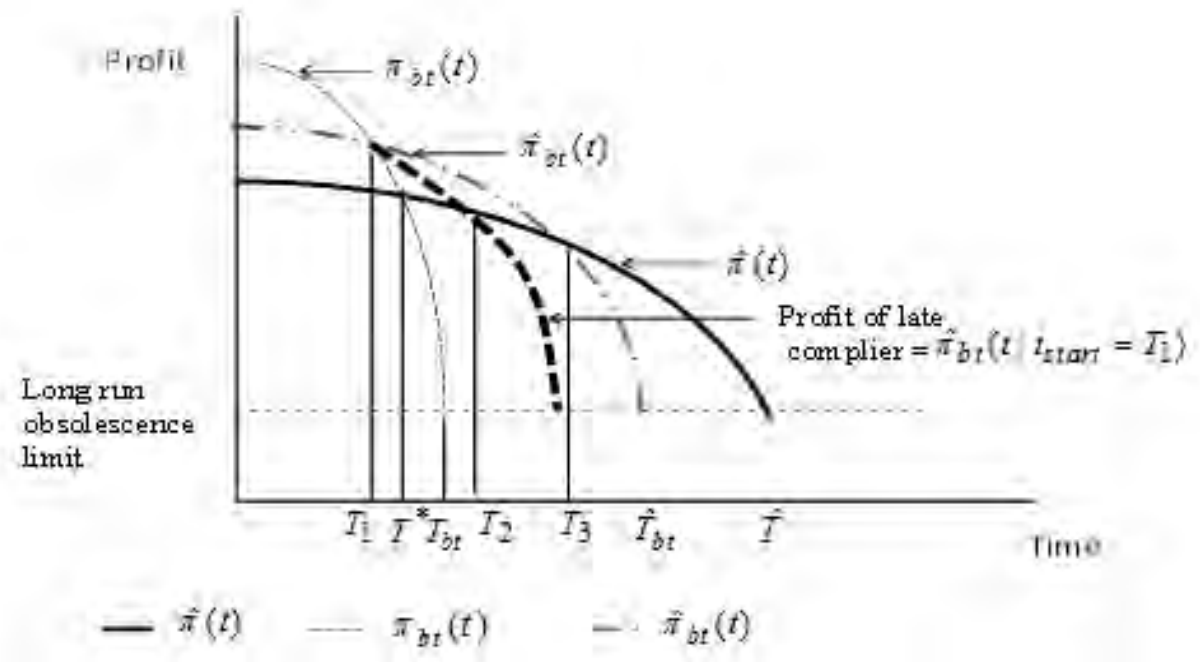

Figure 5.2 Strict profit dominance of Bt only for limited time

Under scenario 3, the Bt profit curve with compliance strictly dominates the profit from conventional variety, while the Bt profit curve without compliance strictly 
dominates for a limited time period only. The logic follows in the same fashion and hence is not dealt with here. This completes our description of settings.

\subsubsection{Dynamics of new technology adoption by farmers}

Given the above context, consider the following two stage dynamic game. In the first stage, farmers choose technology, and in the second stage, they decide upon compliance (see Figure 5.3).

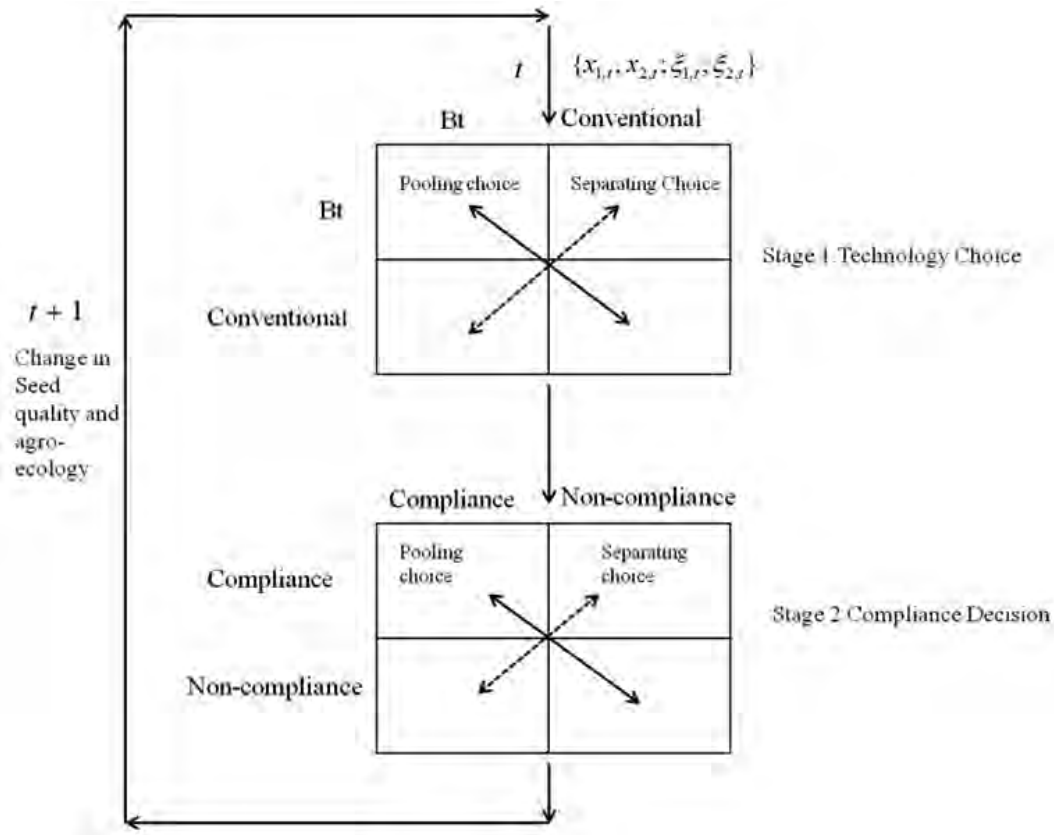

Figure 5.3Two stage game of technology and compliance choice

Farmers can be one of two possible types. The first type is 'profit driven', i.e. his objective function at any time $t$ is to maximize his instantaneous profit as given in equation (7):

$$
\underset{(x, c)}{\operatorname{Max}} \pi_{b t}\left(x, \mathrm{c}, t \mid \xi_{t}\right)
$$

The second type is 'ecologically driven' and his objective function at any time $t$ is to maximize profit over the life time of the technology as shown in equation (8): Moreover by equations (1) - (4) we have: 


$$
\begin{aligned}
& \pi_{b t}(t)>\hat{\pi}_{b t}(t) \text { for } t<\hat{T} \text { but } \pi_{b t}(t)<\hat{\pi}_{b t}(t) \text { for } t>\hat{T} . \\
& \frac{d \pi_{b t}}{d t}<0 ; \frac{d \hat{\pi}_{b t}}{d t}<0 ;(4) \\
& \text { So for } t>\hat{T}_{\text {also }} \pi_{b t}(t)<\hat{\pi}_{b t}(t) \\
& \Rightarrow \int_{t=\hat{T}}^{T} \hat{\pi}_{b t}(t) d t>\int_{t=\hat{T}}^{T t} \pi_{b t}(t) d t \\
& \text { So certainly equation (9) holds for } t>\hat{T} \text {. } \\
& \text { about } t<\hat{T} \text {. Consider } t=t 1<\hat{T} \\
& \text { We need to show: }\left[\int_{t=t 1}^{T} \hat{\pi}_{b t}(t) d t\right]>\left[\int_{t=t 1}^{T} \pi_{b t}^{b t}(t) d t\right] \\
& \text { We know that } \int_{t=0}^{T} \hat{\pi}_{b t}(t) d t>\int_{t=0}^{T} \pi_{b t}^{b t}(t) d t \text { from (1) } \\
& {\left[\int_{t=0}^{t 1} \hat{\pi}_{b t}(t) d t\right]+\left[\int_{t=t 1}^{T} \hat{\pi}_{b t}(t) d t\right]>\left[\int_{t=0}^{t 1} \pi_{b t}(t) d t\right]+\left[\int_{t=t 1}^{T} \pi_{b t}(t) d t\right]} \\
& \Rightarrow\left(\left[\int_{t=t 1}^{T} \hat{\pi}_{b t}(t) d t\right]-\left[\int_{t=t 1}^{T} \pi_{b t}^{b t}(t) d t\right]>\left(\left[\int_{t=0}^{t 1} \pi_{b t}(t) d t\right]-\left[\int_{t=0}^{t 1} \hat{\pi}_{b t}(t) d t\right]\right)\right.
\end{aligned}
$$

Now right hand side of above is always positive by equation (2) and because

$$
t 1>\hat{T}
$$

Therefore, ecologically driven farmers will always observe compliance, while the profit driven farmer will comply only if it pays him to do so.

We make the standard assumptions of rational farmers with perfect and complete information. At the beginning of each time period, each farmer chooses between 
three options: traditional seed technology with compliance, Bt seed technology (new) without compliance, Bt seed with compliance. At the end of the period, actions of all farmers and outcomes are announced and become known to all. Two parameters of the game would however have evolved: (i) virility of the seed germplasm; (ii) agro-ecological quality - and these also are common knowledge. Given the finiteness of the game choices and players - Nash equilibrium exists or there is a strategy profile in terms of technology choice and compliance that every farmer would adhere to given what the other farmers are doing. Furthermore, given the assumptions of rationality and lack of informational constraints, all farmers can trace the expected profit curves over time for different strategy profiles (or farmer choices in the region) and locate the equilibrium profile. In other words, right from the start of the game, all farmers (i.e. players) have a clear representation of the evolutionary trajectories of profits as either scenario 1 or scenario 2. Even under this artificial setting, there are some interesting features of strategic play that can be inferred as in propositions 1 and 2 .

Proposition 1: Even with the same resource endowments, agent heterogeneity can lead to pooling (i.e. same across types) or separating (i.e. different across types) farmer choices in terms of 'technology adoption' and 'compliance'.

Proof: Consider scenario 1 of Figure 5.1 with strict dominance of Bt trajectory with or without compliance, i.e.:

$$
\begin{aligned}
& \pi_{b t}(t)>\hat{\pi}(t) \text { and } \hat{\pi}_{b t}(t)>\hat{\pi}(t) \text { for all } 0 \leq t \leq \max \left\{\hat{T}, T^{b t}, \hat{T}^{b t}\right\} \\
& \pi_{b t}(t)>\hat{\pi}_{b t}(t) \text { for } t<T_{1} \text { but } \pi_{b t}(t)<\hat{\pi}_{b t}(t) \text { for } t>T_{1} \\
& \pi_{b t}<\hat{\pi}_{b t}\left(t \mid t_{\text {start }}=T_{1}\right)<\hat{\pi}_{b t} \text { for } t>T_{1}
\end{aligned}
$$

By (10a) both farmer types adopt Bt, because with or without compliance the new technology yields higher returns at every point in time and therefore over the life time of the technology also. Till time $t=T_{1}$, the economically driven farmer does not comply but thereafter he does by (10b). And from equation (5) we have (10c), which implies that late complier's gains will be less than that of farmer who observes compliance from the start. Thus, that till time $t=T_{1}$ the two farmer types observe different compliance strategies, but afterwards both types comply. 
Now let us turn to scenario 2, with limited time strict dominance of Bt trajectory with or without compliance. Given (10b), and in addition, the curves of Figure 5.2 with $T_{1}<T^{*}<T_{2}<T_{3}$, we have:

$$
\begin{aligned}
& \pi_{b t}(t)<\hat{\pi}_{b t}(t) \text { for } t>T_{1} \text { and } \pi_{b t}(t)<\hat{\pi}(t) \text { for } t>T^{*}>T_{1} ; \\
& \hat{\pi}_{b t}\left(t \mid t_{\text {start }}=T_{1}\right)>\hat{\pi}(t) \text { for } T_{1}<t<T_{2} \text { and } \\
& \hat{\pi}_{b t}\left(t \mid t_{\text {start }}=T_{1}\right)<\hat{\pi}(t) \text { for } t>T_{2} ; \\
& \hat{\pi}_{b t}(t)>\hat{\pi}(t) \text { for } t<T_{3}<\hat{T}^{b t} \text { and } \hat{\pi}_{b t}(t)<\hat{\pi}(t) \text { for } t>T_{3} .
\end{aligned}
$$

Consider the profit driven farmer. As per equations (10b) and (11a) he will adopt the new technology without compliance till time $T_{1}$ and then initiate compliance. He will continue with Bt till time $T_{2}$, when even with compliance Bt yields the same returns as the conventional variety by equation (11b). Therefore, the profit driven farmer will switch to the conventional variety after $T_{2}$.

Let us now turn to the ecologically driven farmer. We know he will always comply and therefore his profit trajectory is given by $\hat{\pi}_{b t}(t)$. Then at the start i.e. $t=0$, the ecologically driven farmer will adopt Bt if and only if equation (12) is satisfied.

$$
\int_{t=0}^{\max \left(\hat{T}^{b t}, \hat{T}\right)} \hat{\pi}_{b t}(t) d t>\int_{t=0}^{\max \left(\hat{T}^{b t}, \hat{T}\right)} \hat{\pi}(t) d t .
$$

In cases where it is satisfied, by equation (11c), $\hat{\pi}_{b t}(t)<\hat{\pi}(t)$ for $t>T_{3}$, and hence:

$$
\int_{t=T 3}^{\max \left(\hat{T}^{b t}, \hat{T}\right)} \hat{\pi}^{b t}(t) d t<\int_{t=T 3}^{\max \left(\hat{T}^{b t}, \hat{T}\right)} \hat{\pi}(t) d t .
$$

However, since all profit curves are continuous and downward sloping, there exists a time period before $T_{3}$ at which the above inequality will hold and the ecologically driven farmer will also switch to the conventional variety. Thus, in case the 
ecologically driven farmer adopts, he will switch to the conventional variety at some time before $T_{3}$ under scenario 2 .

Thus, under scenario 2, pooling and separating strategies will again be observed in terms of technology and compliance choice of the two farmer types and this completes our proof of proposition 1.

\subsubsection{Impact profiles in the post-adoption phase}

We now turn to the possible economic and ecological impact of adoption in a region with many farmers.

Proposition 2: Under the given setting (equations 1-6), even without agent heterogeneity, diverse resource endowments can lead to heterogeneous economic impact experiences under complete adoption, but both farmer types would have experienced an increase in profit.

Consider a region with only profit seeking farmers who have all adopted the new technology. By definition, they would have adopted it only if they expected higher profit from doing so. Hence, under rational expectations and lack of informational constraints, all profit driven farmers $i$ should have experienced an increase in profit vis-à-vis the conventional technology.

Now consider a region with only ecology driven farmers, who have all adopted the new technology at time $t=\tilde{t}$. If they had experienced a fall in profit vis-à-vis the conventional technology, by our assumptions of technology obsolescence (1-4) and continuity of profit functions, we would have:

$$
\begin{aligned}
& \hat{\pi}_{b t}(\tilde{t})<\hat{\pi}(\tilde{t}) \Rightarrow \hat{\pi}_{b t}(t)<\hat{\pi}(t) \text { for all } t>\tilde{t} ; \\
& \Rightarrow \int_{t \geq \tilde{t}}^{\max \left(\hat{T}^{b t}, \hat{T}\right)} \hat{\pi}^{b t}(t) d t<\int_{t \geq \tilde{t}}^{\max \left(\hat{T}^{b t}, \hat{T}\right)} \hat{\pi}(t) d t .
\end{aligned}
$$

However, this contradicts the premise that ecologically driven farmers had adopted the new technology at $t=\tilde{t}$ by definition of the rationale of ecologically driven farmers.

Therefore, when a new technology is being repeatedly adopted, all farmer types would be experiencing only increase in profit, but there could be other variations in yields and costs. 
At the level of an individual farmer $i$, profit change with respect to new technology can be written as follows:

The profit-effect $\Pi_{i}$ is made up of $A_{i}$ the yield-effect and $B_{i}$ the cost-effect. Simple re-arrangement shows that adopters of any type can experience one of the following three impact profiles as in Table 5.2.

Table 5.2 Possible economic impact profiles of adopters

$\Pi_{i}=p A_{i}-B_{i}$

Yield and Cost change experience configurations for $\Pi_{i}>0$

Impact Profile

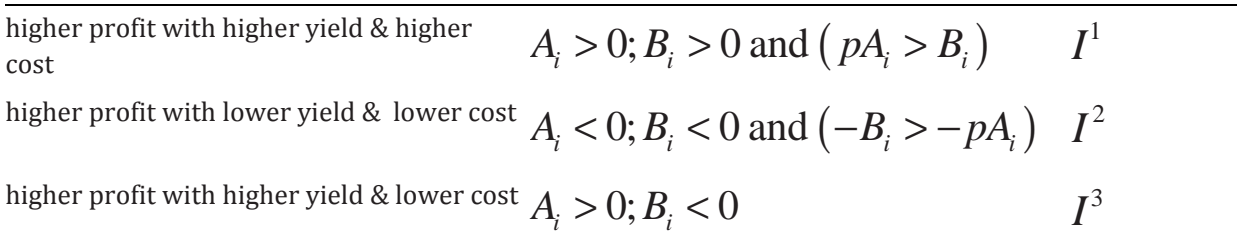

Thus, proposition 2 is proved. Further, it may be recalled that the most frequently experienced impact profile noted in the literature is $I^{1}$ where farmers who switch to Bt benefit from additional profits despite the increase in the cost of cultivation as the increased returns from the yield compensates for the rise in costs.

This completes the theoretical treatment of farmer behaviour.

\subsection{Statistical Analysis}

In order to validate our theoretical model and go further in understanding the relationships between the different types of farmer endowments, farmer types and possible impact profiles, a farmer survey is carried out. Diverse cotton agroecological zones in the state of Andhra Pradesh (after 2 June 2014, Andhra Pradesh and Telangana) are considered. In the villages visited in these regions between Nov 2011 to April 2012, almost all farmers had adopted Bt cotton; and thus, the final sample includes 127 farmers who have adopted Bt cotton. Thereafter, the features of the sample data are identified and analysed to estimate the determinants of economic and ecological impact experience.

\subsubsection{Sample design, sample description and choice of final variables for model estimation}

A semi-structured questionnaire was initially designed to extract information on five variables: farmer type (V1), farmer endowments (V2), compliance (V3), eco- 
nomic impact (V4) and ecological impact (V5) (see Table A5.1 in appendix). Further, each variable was defined by a vector of indicators. The questionnaire was tested in 10 focus group discussions for refinement. The focus group discussions and individual farmer interviews are carried out with the institutional support of Agri Biotech Foundation (ABF) India. The interactions with farmers are made possible as a participant observer of ABF's programmes on agri-biotech awareness and technology outreach. The focus group discussions yielded one major insight outside the scope of the conceptual model. Farmers were found to be not of two but three types. In addition to profit driven and ecologically driven farmers, there were those driven by imitation.

Farmer type or variable V1, was inferred from responses to two questions on farmers' take on technologies in general, i.e. initial preferences; and on Bt in particular, i.e. reasons for reusing Bt season after season, as shown in Table 5.3.

Table 5.3Indicators of farmer type (V1)

\begin{tabular}{|c|c|c|c|c|c|c|}
\hline \multicolumn{7}{|c|}{ Answers to question: In considering a new technology, how would you rank the following? (V1a) } \\
\hline Criteria to rank & Rank 1 & Rank 2 & Rank 3 & \multicolumn{2}{|c|}{ Irrelevant } & Total Responses \\
\hline Immediate profit & 62 & 9 & 5 & 1 & \multicolumn{2}{|c|}{77} \\
\hline Ecological sustainability & 17 & 10 & 16 & 39 & \multicolumn{2}{|c|}{82} \\
\hline Imitation of successful farmers & 7 & 53 & 8 & 4 & \multicolumn{2}{|c|}{72} \\
\hline \multicolumn{7}{|c|}{ Answer to question: Why do you re-use Bt every season? (V1b) } \\
\hline Possible reasons & Rank 1 & Rank 2 & Rank 3 & Rank 4 & Irrelevant & Total Responses \\
\hline Non-availability of non-Bt & 1 & 5 & 6 & 0 & 48 & 60 \\
\hline Higher profit & 65 & 5 & 1 & 0 & 0 & 71 \\
\hline \multicolumn{2}{|l|}{ Imitation of successful farmers 4} & 46 & 5 & 1 & 5 & 61 \\
\hline Ecological concerns & 12 & 0 & 5 & 0 & 46 & 63 \\
\hline
\end{tabular}

These results confirm and refine our model. The profit driven type forms the majority, authenticating that technology choice is primarily driven by expected profit. The imitation driven type come next, followed last by the ecologically concerned type.

Since V1 is measured by two variables, V1a and V1b, a Chi-square test (Chi$2=49.78$, p-val $=0$ ) was carried out followed by a correspondence analysis to test for correlation between V1a and V1b. Rightly, a strong correlation was revealed between 'farmer responses for the reasons for adopting any new technology' (profit increase, ecological returns or imitation) and the 'reason for the re-use of $\mathrm{Bt}^{\text {' }}$ (non-availability of non-Bt, profit increase, ecological returns or imitation). Farmers who were motivated by a given reason (e.g. profit increase) for adopting a 
technology were generally motivated by the same reason for the reuse of Bt. Thus, in what follows we use only V1a as the indicator of farmer type.

In farmer endowments, V2, Age, Education, Farm Size, Family Labour, Years of Experience, Soil type and Irrigation type were considered. A partial description of V2 is given in Table 5.4. 124 farmers answered questions on age, education and irrigation revealing that $55.65 \%$ were between 35 to 55 years of age, $10.48 \%$ were older than 55 and $33.87 \%$ were below 35 . About $16.9 \%$ were illiterate, $25 \%$ had primary school education, $50.8 \%$ went to middle or high school and finally, $7.2 \%$ had university diplomas. Only $26.61 \%$ of the farms were purely rain-fed, $14.52 \%$ were partially irrigated while $58.87 \%$ were completely irrigated.

Table 5.4Farmer Endowments (V2)

\begin{tabular}{|c|c|c|c|c|c|}
\hline $\begin{array}{l}\text { No. of Villages / } \\
\text { District }\end{array}$ & State & $\begin{array}{l}\text { Cotton agro-clima } \\
\text { zones }\end{array}$ & $\begin{array}{l}\text { Sample size: } \\
127\end{array}$ & $\begin{array}{l}\text { Type of soil } \\
\text { (black; non- } \\
\text { black or } \\
\text { mixed) }\end{array}$ & $\begin{array}{l}\text { Farm Size } \\
(\text { small }<=5 \\
\text { acres ; large) }\end{array}$ \\
\hline 13 villages, Warangal & Telangana & North Telangana & 61 & $29 ; 32$ & $29 ; 32$ \\
\hline 3 villages, Adilabad & Telangana & North Telangana & 31 & $25 ; 4^{*}$ & $17 ; 14$ \\
\hline 3 villages, Kurnool & Andhra Pradesh & Rayalaseema & 18 & $1 ; 16^{*}$ & $5 ; 13$ \\
\hline 9 villages, Nellore & Andhra Pradesh & South Coastal & 17 & $8 ; 9$ & $2 ; 15$ \\
\hline
\end{tabular}

*The totals do not add because of missing data for these variables

A principal component analysis of the quantitative indicators of V2 revealed high correlation between the different indicators that could be subsumed into two main factors. The first factor related to size including: Farm-size, Family-size and Family-labour which were positively related to one another. The second contained the rest being related positively to Age and Experience and negatively to Education. Thus, only two variables were finally used to represent farmer endowments: Farmsize and Education.

Coming to farmer compliance behaviour, V3, only 46 out of 104 farmers revealed that they observed refuge compliance.

With respect to economic impact V4, farmers were asked about change in profit, cost and yield as summarized in Table 5.5. Answers confirm Proposition 2 that new technology adopting farmers can experience a variety of economic impact profiles and the finding of the economics literature that the most prevalent impact profile is: 'increase in profit' along with 'increase in production cost' and 'increase in yield'. However a majority of farmers when asked about the growth in yield within Bt reported that there is a decrease in the yield year on year in Bt i.e., the yield increase was highest during the initial years of adoption and then decreased as the years went by. 
Table 5.5 Economic outcomes of Bt growing farmers (V4)

\begin{tabular}{llll}
\hline Average change/Component & Net Profits & Costs & Yield \\
\cline { 2 - 4 } & Number of farmers & Number of farmers & Number of farmers \\
\hline Increase & 60 & 72 & 59 \\
Decrease & 9 & 26 & 8 \\
No change & 32 & 3 & 34 \\
Total Responses & 101 & 101 & 101 \\
\hline $\begin{array}{l}\text { Profile explanation (Total responses= } \\
\text { higher profit, higher yield, higher cost }\end{array}$ & Profile type & Number of responses \\
higher profit, lower yield, lower cost & I1 & 25 \\
higher profit, higher yield, lower cost & I2 & I3 & 2 \\
lower profit, higher yield, higher cost & I4 & I5 & 11 \\
lower profit, lower yield, higher cost & & 4
\end{tabular}

Table 5.5 also confirms that the ideal conditions of the model do not hold in reality as illustrated by the presence of profiles I4 and I5, which can be assumed to be due to wrong judgment on the part of the farmer. For model estimation, since no impact profile contains more than 25 observations, none were a good choice to represent economic impact. On the other hand, since we had 101 observations on profit perceptions, it was retained as the indicator of economic impact.

Ecological externalities (V5) were inferred from questions relating to two types of impacts. First, bio-physical changes were considered in terms of soil fertility, productivity of adjacent fields or subsequent crops, higher pest and disease incidence. Second, direct health repercussions on animals and humans were identified: health of cotton oil consumers, health of the cultivator and cattle/animal health. The answers of 106 farmers are presented in Figure 5.4. 


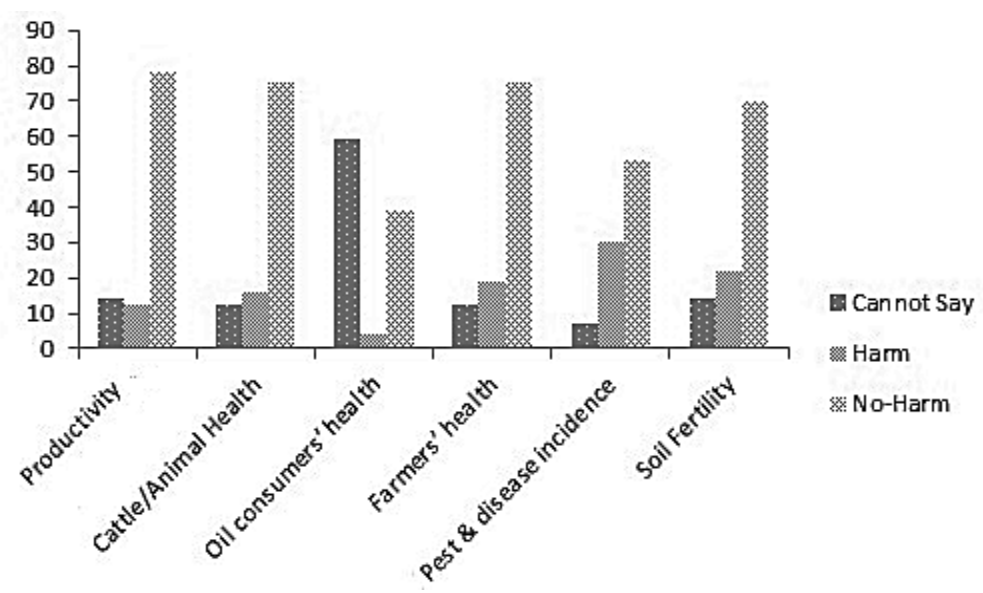

Figure 5.4 Farmer perceptions on ecological impact and other externalities generated by Bt (V5).

As Figure 5.4 reveals, the main ecological externality noted by the surveyed farmers is the resurgence of secondary pests. Farmers also explained that they cannot give an opinion on the health effects of oil consumers as they do not consume cotton seed oil. Thus, proposition 2 is confirmed that ecological impacts can be diverse for $\mathrm{Bt}$ farmers in the same region.

To analyse the relations between the different dimensions of ecological impact and see whether some could be grouped into homogeneous classes, a multiple correspondence analysis was used. It revealed that the six ecological dimensions could be grouped into three homogeneous classes of which only the first two were relevant for model estimation. Generally farmers gave the same answer (either damage or no damage) vis-à-vis impact on soil fertility, productivity (of adjacent fields and the crops in the same field in the next season), animal health and health of farmers. These variables seem to be driven by the same forces and can therefore be subsumed into 'local externalities' as they are contained to farm and the farmer. However, pest and disease infestation, which can spread across farms, was perceived as negative by more farmers $33 \%$ of the interviewed farmers answered that $\mathrm{Bt}$ is triggering higher pest and disease infestation, against $12 \%$ for damaging the productivity and 15\% for causing animal health issues). Finally, the health of cotton oil consumers was marked apart mainly, because most of the answers were 'can't say' implying that this impact is not a credible one for our sample. Moreover, crossing ecological perception with farmer type, it was confirmed that ecological farmers are more mindful of possible Bt externalities. 


\subsubsection{Bivariate analyses of model variables}

We then carried out bivariate analyses between the final variables of the conceptual model and this yielded Table 5.6, where the significant relations between the model variables are described. Qualitative-qualitative relations were analysed by Chi-square tests and correspondence analyses while qualitative-quantitative relations were analysed by F-tests and ANOVA (or T-tests when the variance equality assumption was rejected by Levene's test).

Table 5.6 Salient features of significant (at $5 \%$ ) bivariate relations

\begin{tabular}{|c|c|c|c|c|c|c|}
\hline & \multicolumn{3}{|c|}{ Farmers' characteristics } & $\begin{array}{l}\text { Economic } \\
\text { Impact }\end{array}$ & \multicolumn{2}{|c|}{ Ecological Impact } \\
\hline & V2.3 Farm Size & $\begin{array}{l}\text { eV2.6 } \\
\text { Irrigation }\end{array}$ & $\begin{array}{l}\text { V3 } \\
\text { Refuge Compli- } \\
\text { ance }\end{array}$ & $\begin{array}{l}\text { V4.2 } \\
\text { Profit } \\
\text { Perception }\end{array}$ & $\begin{array}{l}\text { V5a.1 } \\
\text { Soil } \\
\text { Fertility }\end{array}$ & $\begin{array}{l}\text { V5a.3 } \\
\text { Pest/Disease } \\
\text { Incidence }\end{array}$ \\
\hline $\begin{array}{l}\text { V1.a } \\
\text { Farmer } \\
\text { Type }\end{array}$ & $\begin{array}{l}\text { Ecologically } \\
\text { driven have } \\
\text { smaller farm- } \\
\text { ers }\end{array}$ & $\begin{array}{l}\text { Ecologically } \\
\text { driven farmers } \\
\text { are likely to } \\
\text { have rain-fed } \\
\text { farms }\end{array}$ & $\begin{array}{l}\text { Ecologically } \\
\text { s driven farmers } \\
\text { are more likely } \\
\text { to be compliant }\end{array}$ & - & - & $*$ \\
\hline V2.3 Farm.Size & & $\begin{array}{l}\text { Generally, } \\
\text { large farms are } \\
\text { irrigated and } \\
\text { small ones are } \\
\text { rain-fed }\end{array}$ & & $\begin{array}{l}\mathrm{s} \\
\mathrm{p} \\
\mathrm{f} \\
\mathrm{i}\end{array}$ & $\begin{array}{l}\text { Smaller } t \\
\text { perceptic } \\
\text { fertility a } \\
\text { infestatic }\end{array}$ & $\begin{array}{l}\text { he farm higher the } \\
\text { on of impact on soil } \\
\text { ind pest and disease } \\
\text { on }\end{array}$ \\
\hline $\begin{array}{l}\text { V2.5 } \\
\text { Soil }\end{array}$ & - & $\begin{array}{l}\text { Mixed soil } \\
\text { (non-black) } \\
\text { farms are } \\
\text { more likely to } \\
\text { be irrigated }\end{array}$ & $*$ & - & $*$ & - \\
\hline $\begin{array}{l}\text { V2.6 } \\
\text { Irrigation }\end{array}$ & & & - & $\begin{array}{l}\mathrm{I} \\
\mathrm{t} \\
\mathrm{s} \\
\mathrm{c}\end{array}$ & $\begin{array}{l}\text { If farm is } \\
\text { the perce } \\
\text { soil fertil } \\
\text { disease il }\end{array}$ & $\begin{array}{l}\text { rain-fed, higher is } \\
\text { ption of impact on } \\
\text { ity and pest and } \\
\text { nfestation }\end{array}$ \\
\hline $\begin{array}{l}\text { V3 } \\
\text { Ref.Comp }\end{array}$ & - & - & & $\begin{array}{l}\text { Non- } \\
\text { compliance- } \\
\text { leads to } \\
\text { higher } \\
\text { profit } \\
\text { percept. }\end{array}$ & & - \\
\hline
\end{tabular}

Notes: Explanation is given for relationships significant at 5\%.(*) indicates that the relation is only significant at $10 \%$ but not at $5 \%$.(-)indicates that the relation is not significant at $10 \%$.

The findings can be summarized as follows. There are three global homogeneous clusters of farmers. The first group consists of ecologically driven farmers who generally have small farms, use rain-fed irrigation and have black soil. They are slightly more educated (average education is 8.6 years for ecologically driven 
farmers as against 6.8 years for the profit seekers) and are more aware of the negative ecological impacts of Bt and are largely refuge compliant. The second group comprises profit driven farmers with larger, irrigated and mixed soil farms. Finally, the third group is made up of imitators, who are much older than farmers of the previous groups (an average age of 51 against 41 in the other groups) and are generally not refuge compliant.

\subsubsection{Estimation of determinants of economic and ecological impact}

From Table 5.6, we note that the economic impact of Bt adoption as given by the change in profit is most explained by land size and compliance behaviour. To further identify the nature of this relationship, a model estimated by a multinomiallogistic regression is given by equation (16) and detailed further in Table 5.7.

$$
\frac{\text { Prob[Prof.Increase }]}{\text { Prob[Prof.Decrease }]}=\exp \left[2.81+0.11 \text { FarmSize }-3.00 \text { Dum }_{\text {Compliance }}\right]
$$

Table 5.7 Logistic regressions modelling farmers' perceptions of impact

\begin{tabular}{|c|c|c|c|c|c|c|c|}
\hline \multirow[b]{3}{*}{ Variables } & & \multirow{2}{*}{\multicolumn{2}{|c|}{$\begin{array}{l}\text { Economic Impact } \\
\text { V4.2 Profit Perception }\end{array}$}} & \multicolumn{4}{|c|}{ Ecological Impact } \\
\hline & & & & \multicolumn{2}{|c|}{ V5a.1 Soil Fertility } & \multicolumn{2}{|c|}{$\begin{array}{l}\text { V5a.3 Pest \& Disease } \\
\text { Incidence }\end{array}$} \\
\hline & & $\begin{array}{l}\text { Profit In- } \\
\text { crease }\end{array}$ & $\begin{array}{l}\text { Profit } \\
\text { Stable }\end{array}$ & Damage & Can't say & Damage & Can't say \\
\hline \multirow[t]{2}{*}{ V1.a Farmer Type } & $\begin{array}{l}\text { Ecologically } \\
\text { driven }\end{array}$ & & & & & $1.605^{* *}$ & 1.409 \\
\hline & Imitators & & & & & 1.770 & 2.018 \\
\hline V2.2 Education & & & & 0.054 & 0.037 & & \\
\hline V2.3 Farm.Size & & 0.114 & 0.135 & -0.050 & -0.113 & $-0.160^{* *}$ & -0.067 \\
\hline \multirow[t]{2}{*}{ V2.5 Soil } & Black soil & & & 0.204 & 0.683 & & \\
\hline & Mixed soil & & & 0.487 & $2.252^{* * *}$ & & \\
\hline V3 Ref.Comp & Compliance & $-3.000^{* * *}$ & -1.584 & & & & \\
\hline Intercept & & $2.812^{* *}$ & 1.365 & $-1.193^{*}$ & $-1.746^{*}$ & 0.266 & $-1.438^{*}$ \\
\hline $\begin{array}{l}\text { R-squared } \\
\text { (Nagelkerke) }\end{array}$ & & 0.247 & & 0.166 & & 0.293 & \\
\hline $\begin{array}{l}\text { Perc. correct classi- } \\
\text { fication }\end{array}$ & & $63.0 \%$ & & $65.7 \%$ & & $62.3 \%$ & \\
\hline
\end{tabular}

Notes: ${ }^{* * *},{ }^{* *}$ and ${ }^{*}$ represent statistical significance of Wald test at $1 \%, 5 \%$ and $10 \%$ respectively. The reference categories for the qualitative variables are: 'Profit seekers' for V1.a, 'No-compliance'. For V3, 'Non-black soil' for V2.5, 'Profit decrease' for V4.2 and 'No-damage' for V5a.1 and V5a.3.

The empirical model indeed confirms that while the perception of profit increase is positively related to the farm size, it is much more significantly (negatively) related to compliance behaviour. Non-compliant farmers declared massively $(75 \%$ of them) that they got higher profits with Bt while compliant farmers are more miti- 
gated $46 \%$ of those observing compliance declared that Bt and conventional seeds lead to equivalent profits and only $37 \%$ declared that they got higher profits with Bt) confirming our assumption on initial lower returns with compliance.

This points out to an interesting puzzle. Are profit driven farmers born that way or are they made to behave that way due to their resources? While the causality is not clear, the results point to the latter explanation and seem to indicate the following refinement of our model - at least in the beginning of the life time of a technology. Let 'farm size' be given by L; then we have:

$$
\frac{d\left[\pi_{b t}(L)-\hat{\pi}_{b t}(L)\right]}{d L}>0
$$

The difference between profit to non-compliance and compliance increases with size of the land holding. This means that it is in the interests of all farmers with land holdings beyond a certain limit not to comply, i.e. act as small barons who will not lose their time and efforts in compliance annoyances. However, for smaller farmers, the marginal difference is not worthwhile not to comply.

Recall that ecological impact is represented as impact on soil fertility and pest and disease infestations. Again from Table 5.6, perceptions of damage to soil fertility seem to depend strongly on farmers' education, farm-size, and soil and irrigation types. But as irrigation is strongly correlated to farm size and soil-type, it was removed from the explanatory variables. Similarly, the increase in secondary pests and disease infestations is most correlated to farmer type, farm size and irrigation type. But there is a significant correlation between farmer type and irrigation type and hence only farmer type and farm size were taken as explanatory variables. This leads to the following two models estimated again by multinomial-logistic regression method as in equations (18) and (19) and Table 5.7.

$\frac{\text { Prob }[\text { SF.Damage }]}{\text { Prob[SF.No.Damage }]}=\exp \left[-1.19+0.05\right.$ Educ. -0.05 FarmSize +0.20 Dum $_{\text {Blacksoil }}+$
0.49 Dum
Mixedsoil $]$

The interpretation of equation (18) is not totally evident since only the intercept is statistically significant. But it seems to confirm that the perceptions of damage to soil are more acute for more educated farmers having small (generally rain-fed) farms.

$\frac{\text { Prob[PDI.Damage }]}{\text { Prob[PDI.No.Dam }]}=\exp \left[0.27-0.16\right.$ FarmSize +1.60 Dum $_{\text {Ecolog }}+1.77$ Dum $\left._{\text {Imitat. }}\right]$ 
The regressions confirm that the perception of pest and disease infestations is significantly higher for small farms owners and ecologically driven type. From these results it is clear that small farmers are generally more mindful of Bt's (new technology's) ecological externalities, which could also be because they are more fragile economically. Moreover, this awareness increases for educated and ecologically driven farmers.

\subsection{Discussion}

This chapter sought to examine how sustainability concerns are integrated in the drivers of new technology adoption. It is noticed that an important reality of agricultural production is missing in the production function based impact analyses of agricultural technology adoption. Seed innovations have built-in technology obsolescence and the trajectory of their returns depends on the systemic changes they engender in the ecology due to implementation practices. This aspect is incorporated in a model along with the premise of farmer heterogeneity. The assumption is that all farmers need not seek to maximize short term profit; some can be more concerned about sustainable profit. The model highlighted four noteworthy points.

First, even if farmers in a region have the same resource endowments, heterogeneity in terms of farmer type can give rise to different technology choices and compliance behaviour, which in turn engender different ecological impacts as well. By extension of the argument, at a macro level, the regional impact would also depend on the size of the farmer population and the proportion of the two farmer types. Therefore in principle, different farmer type compositions of same sized populations can experience different evolutionary trajectories in outcomes.

Second, while the model was set in artificial conditions of rational farmers with perfect and complete information, in reality, these do not hold. There is real uncertainty on the forms of the profit trajectories, due to a combination of scientific and market uncertainty coupled with incomplete information. The impact of compliance is also not very clear. Therefore, evaluations and choices are made on the basis of subjective beliefs, which give rise to a greater variety of belief-based farmer types. Moreover, going beyond farmers, there can be other systemic actors with a variety of beliefs. Thus, a multiplicity of mutually exclusive subjective views based on incomplete and imperfect information of the ecological impact of GM crops seems to be the source of controversy, sanctioning the arguments made in chapter 4.

Third, the model also provides another illustration of the trade-offs between short term strategic flexibility and long term irreversibility that is actor generated (Ramani and Richard, 1993). Profit seeking farmers have more strategic flexibility (they can comply or not comply) and they trade this against the risk of engender- 
ing more irreversible agro-ecological changes. But due to externalities, they also cause irreversible damage to other compliant farmers.

Fourth, by the above, even the classical assumptions of rationality and lack of informational problems do not ensure systemic viability. For instance, if there is an ecologically damaging technology, and if a majority of farmers apply it without observing the guidelines, then through negative externalities the system as a whole would suffer. Thus, the exit of all farmers due to lack of economic viability, i.e. a social dilemma is a possible outcome.

To validate and refine the model, a survey of a set of farmers who adopted Bt was carried out. It showed that the majority of farmers are driven by profits and the most prevalent economic outcome profile from Bt adoption is one wherein the profits, costs and yields - all increase. But, the empirical study went beyond the literature to confirm the assumption of farmer heterogeneity. Not only are there profit seekers and ecologically concerned farmers sensitive to changes in the environment, but there is also a sizeable population that simply imitates the technology strategy of whichever farmer is most successful in their locality. Though outside the scope of this study, future research can examine whether the adoption rationale of imitative farmers is driven by ignorance, a state of indebtedness, or the degree of variance of their income (i.e. risk aversion).

Further, there is a close association between resource endowments and farmer type. According to our analysis, profit driven farmers are likely to be older with larger and irrigated farms; while the opposite holds for the ecologically driven. In turn, farmer type determines compliance behaviour with ecologically driven farmers being more willing to be compliant than other types, which simply view noncompliance as a way to increase short term profit.

Impact experiences of Bt cotton are heterogeneous. The economic impact in terms of profit seems to increase with farm size and ready access to water. The perception of profit increase is negatively related to refuge compliance. Interestingly, negative local ecological changes, which are partially controllable consequences of farm practices, are perceived more by educated small farmers with rain fed land, indicating scope for further awareness creation given this sensitivity. But, increase in secondary pests and infestations, another uncontrollable externality, is independent of education but again more perceived by small ecologically driven farmers with rain-fed land. Thus, a large farm size and access to water seem to be good buffers to protect farmers' profit against the vagaries of nature, reinforcing the fact that small rain fed farmers are the most vulnerable group. 


\section{Appendix}

\section{Table A5.1 Variables included in the primary survey}

\begin{tabular}{lll}
\hline Variable & Explanation & Values/Scale \\
\hline Farmer Type: what influences technology choice V1a & \\
V 1a.1:Profit driven & Weightage given to economic & Quantitative: \\
V 1a.2: Ecologically driven & returns, social factors and ecologi- & Irrelevant \\
V 1a.3:Imitation driven & cal considerations while choosing a Rank 1 & Rank 2 \\
& technology & Rank 3 \\
\hline
\end{tabular}

Farmer type: why do you reuse Bt cotton V1b

V 1b.1: Non availability of non-Bt Ranking of each factor

Quantitative:

hybrids in the market

Irrelevant

V 1b.2:Increased economic returns

Rank 1

V 1b.3:Imitation

Rank 2

V1b.4: Ecological reasons such as

Rank 3

improved health

Rank 4

Farmer Endowments V2

\begin{tabular}{|c|c|c|}
\hline V 2.1: Age & Age of the farmer in years & Quantitative \\
\hline V 2.2: Education (Number of Years) & $\begin{array}{l}\text { Number of years of education of } \\
\text { the farmer }\end{array}$ & Quantitative \\
\hline V 2.3: Land size (Own / leased/ Total) & $\begin{array}{l}\text { In Acres (apx. } 2.5 \text { acres is } 1 \text { Hec- } \\
\text { tare) }\end{array}$ & Quantitative \\
\hline V2.4: Family Size & $\begin{array}{l}\text { Number of persons in the house- } \\
\text { hold working in the farm }\end{array}$ & Quantitative \\
\hline V 2.5: Soil type & Type of the soil & $\begin{array}{l}\text { Qualitative: Black, } \\
\text { Red/Mixed, combination }\end{array}$ \\
\hline V 2.6: Irrigation type & $\begin{array}{l}\text { Type of the irrigation for cotton } \\
\text { fields }\end{array}$ & $\begin{array}{l}\text { Qualitative: Dug well, Bore } \\
\text { well, Canal, Tank, Rain-fed, } \\
\text { Other types }\end{array}$ \\
\hline \multicolumn{3}{|c|}{ Compliance behaviour - Farmer routines V3 } \\
\hline V3: Refuge Compliance & $\begin{array}{l}\text { Compliant with planting non-Bt } \\
\text { cotton around Bt cotton fields }\end{array}$ & $\begin{array}{l}\text { Quantitative: } \\
\text { 1: Yes } \\
-1 \text { : No }\end{array}$ \\
\hline
\end{tabular}

Economic impact - Outcomes V4

\begin{tabular}{lll}
\hline V 4.1: Yield & Economic impact perceptions: & 1.Significant increase \\
V 4.2: Profits & Aggregate change in the variables & 2. increased \\
V 4.3: Total Cost of Cultivation & as compared to conventional hy- & 3. reduced \\
& brid cotton cultivation & 4. greatly reduced \\
& & 0. No difference
\end{tabular}

Ecological externalities - Outcomes V5a

V 5a.1 : Soil Fertility Impact perception on each of the

V 5a.2: Productivity of adjacent ecological entities 1. Damage

farms/subsequent crops

-1 . No damage

V 5a.3:Pest and Disease infestation

0. Cannot say

\begin{tabular}{|c|c|c|}
\hline \multicolumn{3}{|l|}{ Other externalities Vector - Outcome V5b } \\
\hline $\begin{array}{l}\text { V 5b.1: Animal health } \\
\text { V 5b.2: Health of cotton oil consumers } \\
\text { V 5b.3: Health of cultivators }\end{array}$ & $\begin{array}{l}\text { Impact perception on each of the } \\
\text { dimensions }\end{array}$ & $\begin{array}{l}\text { 1. Damage } \\
-1 \text {. No damage } \\
0 . \text { Cannot say }\end{array}$ \\
\hline
\end{tabular}




\section{Chapter 6. Technology transitions and catching up of local firms}

\subsection{Globalization and catching up in agricultural innovation ${ }^{11}$}

The case of Bt cotton in India clearly illustrates the changes in the dynamics of knowledge creation in the agricultural sector in the back drop of increasing globalization of innovation with the rise of biotechnology. These changes have presented Indian seed firms with interesting and diverse pathways to catch up with a frontier technology. Starting from this premise, this chapter answers the question: How did Indian seed firms catch up in Bt technology? To answer this question, it is also necessary to analyse the role of the technology owner Monsanto, in the catch up process. From the catch-up story of Indian seed firms with Bt technology, the chapter aims to draw insights for catch up strategies of local firms elsewhere to master global frontier technologies.

Our analysis follows the following order. First, the changing context of global-local knowledge interactions against the backdrop of increasing globalization is spelled out. Second, the nature of agricultural innovation processes, which is significantly different from that of the manufacturing or service sector, is pointed out; and third, the impact of the modern biotechnology on agricultural innovation process is briefly discussed. Since a range of factors shape the technological catch up process, a conceptual framework is developed that characterizes the 'knowledge base' essential for agricultural innovation under the above themes. The case of Indian firms and their strategies vis-a-vis Bt cotton is then analysed against that framework. In particular the way in which knowledge is exchanged and created in a collaborative manner between the owner of global 'upstream' scientific knowledge (multinationals such as Monsanto) and the leaders of local 'downstream' in-situ knowledge (Indian seed firms) is examined.

The chapter is organised as follows: in Section 6.2 a survey of the economics and international business literature is carried out to present the theoretical background on the processes of firm-level knowledge creation and technological catch up. In the same section, the peculiarities of agricultural production especially the changing nature of knowledge creation and innovation with the rise of biotechnology are highlighted, and a conceptual framework that characterizes the knowledge base for agricultural innovation is proposed. Section 6.3 analyses in detail the different patterns of Bt technology diffusion in the Indian cotton seed market to draw insights for firm strategy in technological catch-up using the framework. Finally,

11 This chapter is based on a working paper: Michiko Iizuka, Ajay Thutupalli. 2014. Globalization, the rise of biotechnology and catching up in agricultural innovation: The case of Bt technology in India, UNU-MERIT Working Paper 2014-054. 
Section 6.4 concludes with the main findings from the case study, and possible directions of future research in this area.

\subsection{Theoretical background and conceptual framework}

\subsubsection{Firm level knowledge creation - a dynamic process}

In the economics of innovation literature scholars have proposed that the speed and trajectory of innovations is highly heterogeneous and dependent on the national and sectoral systems of innovation (Nelson and Rosenberg, 1993; Lundvall, 1992; Malerba, 2002). While it is important to strengthen innovation systems at the national and sectoral levels, these systems are now increasingly integrated into the global knowledge system. Globalization and subsequent interactions between global and local actors introduced major changes into the processes of knowledge creation. At the same time, the appropriation of knowledge through intellectual property rights (IPR) and its adoption through the TRIPS agreement became important institutions that transformed the way knowledge is transferred between actors (licenses and R\&D collaboration).

Amin and Cohendet (2004) elucidate the recent changes in the knowledge creation and diffusion processes that are significantly accentuated by the process of globalization (Iizuka, 2007). They consider knowledge as no longer a pure public good because its access is determined by the level of appropriation of knowledge. This means that knowledge creation is not a solitary process, rather, a network phenomenon where actors interact with each other. The process of knowledge creation is becoming increasingly collaborative, where the producer of knowledge faces a specific structure of interaction among various agents at distinct levels. The individual gains from such interaction vary due to the variable degree of absorptive capacity (Cohen and Levinthal, 1990).

Table 6.1 Changes in the notion of knowledge and the knowledge creation process with globalization

\begin{tabular}{ll}
\hline Before globalization & After globalization \\
\hline $\begin{array}{l}\text { Knowledge is simple accumulation of information } \\
\text { and is a pure public good; it is not possible to } \\
\text { exclude anyone from using it. }\end{array}$ & $\begin{array}{l}\text { knowledge is variable. } \\
\text { Incentives for knowledge creation are not linked }\end{array}$ \\
$\begin{array}{ll}\text { Incentives for knowledge creation are increasingly } \\
\text { Production of knowledge is often solitary. }\end{array}$ & $\begin{array}{l}\text { linked to its ownership. } \\
\text { Production of knowledge is not solitary; it happens in }\end{array}$ \\
$\begin{array}{ll}\text { The producer of knowledge directly interacts } \\
\text { with the market. }\end{array}$ & $\begin{array}{l}\text { The producer of knowledge faces a specific structure } \\
\text { of interaction among economic agents. }\end{array}$ \\
$\begin{array}{ll}\text { Agents have full capacity to understand existing } \\
\text { knowledge. }\end{array}$ & $\begin{array}{l}\text { There are differences in utilization of existing } \\
\text { knowledge, depending upon absorptive capacities. }\end{array}$ \\
\hline
\end{tabular}

Adapted from Iizuka (2007) and Amin and Cohendet (2004) 


\subsubsection{Pathways for catch up}

The literature on globalization of economic production demonstrates that in the recent past role of producers in developing economies has changed significantly. The global value chain (GVC) literature observes that the role of producers in emerging economies is gradually shifting from low-cost resource and service provision (human, natural and environmental) to less hierarchical, arm's-length supply of products with possibility to upgrade its position in the GVC (Gereffi and Korzeniewicz, 1994; Humphrey and Schmitz, 2000; Humphrey and Schmitz, 2002a; Kaplinsky and Morris, 2001; Gereffi and Kaplinsky, 2001; Humphrey and Schmitz, $2002 b)$. The global production network literature advances this point further to state that producers in emerging economies now have a more equal standing in coming up with the most efficient and productive solutions (Ernst, 2001).

Similarly, in the international business literature, the role of subsidiaries is being reconsidered as a potential source of knowledge within a multinational enterprise's global knowledge network (Birkinshaw and Hood, 1998; Cantwell and Iammarino, 2003). In other words actors in emerging economies are increasingly becoming knowledge collaborators and active partners in knowledge creation instead of being passive users or implementers of knowledge.

Recent findings on GVC by OECD (2013) highlight the importance of knowledgebased capital for upgrading producers' position in the GVC. Knowledge-based capital is understood as tacit, operational or organization-specific knowledge that others find difficult to replicate. While there are differences in types of upgrading (process, product, functional, chain and end-market), all types of upgrading require capacity building through conscious learning and interaction (Kaplinsky and Morris, 2001; Fernandez-Stark et al., 2011). Firms that acquire knowledge-based capital in terms of access to complementary inputs and services can better position themselves in the GVC because they can 'glue' production processes and contribute significantly in maximizing gains from GVC. At the same time, focus of discussions is now shifting to emerging economies with a large domestic market (such as Brazil, Russia, India, China and South Africa), where the scope of knowledge-based capital is increasing due to economies of scale. However, while knowledge-based capital plays a central role in increasing the profitability of a firm, investment in that regard is difficult in the early phase of emerging economic firm activities due to non-excludability of knowledge and associated investment risks.

In the same context, the complex nature of knowledge flows involving MNEs, one of the key players in GVC, and the effect of Intellectual Property Regime (IPR) in emerging economies on these flows is also examined. While several studies show that the strength of the IPR regime influences MNEs' knowledge creation activities in emerging economies, some claim that technology transfer will be limited under 
a weak IPR regime because of less use of licensing (Yang and Maskus, 2001; Branstetter et al., 2006). Other studies indicate that MNEs are likely to engage directly in collaborative knowledge creation (R\&D collaborations) with partner firms located in countries with a weak IPR regime to avoid IPR 'leakage' (Zhao, 2006; Griffith and Miller, 2011).

For a long time, the type of technology transfer that takes place between MNEs and local firms was believed to be concentrated on inexpensive manufacturing or customized products (Nandkumar and Srikanth, 2011). This is however changing in the recent past where collaborations are seen in a variety of sectors. In sum, MNEs' collaboration decisions in emerging countries are influenced by the strength of IPR, the absorptive capacity of local firms, the characteristics of technology and market.

Moving to the economics of innovation literature, the term 'catch up', here, refers to closing of the gap in technological capabilities, leading to increased exports thereby driving the economic growth (Abramovitz, 1986; Perez and Soete, 1988; Lee and Lim, 2001), or, in other words, the process in which followers learn and catch-up with the leaders wherein both follower and leader can be firms, industries or countries. The catch-up process involves learning and learning takes time (Malerba and Nelson, 2011). Some follower country firms may 'leapfrog' to the global technological frontier in quick time (Soete, 1985). While the actors, the knowledge base and the underlying institutions (such as IPR and government policies) all influence the dynamics of catching up, the catch up process itself is characterized by the specificities of the sector in which they occur.

Lim and Lee (2001) through their study of six Korean industries identified three different patterns of catching up: 'path following', 'stage skipping' and 'path creating'. While 'Path following' is the pattern of learning that mostly concerns acquisition of knowledge through adaptation and imitation of existing technology and the processes of its creation; 'stage skipping' is the pattern of learning that involves skipping a certain stage of technology development. 'Path creation' involves creating a new combination of knowledge to move the technology onto a slightly different trajectory. Their study highlights how different sectors choose different learning strategies by combining acquisition and creation of knowledge reflecting different industrial regimes. Moreover, Lee (2013) based on empirical evidence from Korea and Taiwan, identifies that investment in short cycle (rapidly changing and emerging) technologies and localization of knowledge in niche areas are key for successful sustenance of the initial 'catch up'.

Along similar lines, in the international business literature, Prahalad and Mashelkar (2010), based on their study of successful Indian firms, identified diverse 
strategies of combining knowledge. They are, first, creating customized solutions by combining the existing 'off-the-shelf' technologies via licensing (Wipro, Infosys and TCS); second, creating new products by putting together existing technological components in a unique manner (Computational Research Laboratories (CRL) coming up with the fourth-fastest computer with licensed technology); and third, addressing a new market segment with new products or services by selecting and integrating existing technologies (Tata motors ${ }^{12}$ produced a car, 'Nano', priced at $\$ 2000$ addressing the low-income markets). These cases demonstrate that knowledge creation is increasingly dynamic that involves combining existing knowledge in new ways (via licensing) to address new markets, and that local firms in emerging economies are increasingly capable of taking advantage of the opening of the 'windows of opportunity' generated by globalization.

While these theoretical and empirical findings are important, many empirical studies are based on the manufacturing or service sector. The aim of this chapter is to extend these arguments to the knowledge dynamics and catching-up pertaining to the agricultural innovation which has drawn attention of only a few scholars (Shulin $\mathrm{Gu}, 2012$ ). Although the nature of actors, the underlying knowledge base and institutions all can be examined in a catch-up story, in this chapter the focus is restricted to the role of underlying knowledge base.

Agricultural sector, like any other industrial regime, demonstrates peculiar sectoral characteristics originating from the nature of the production processes based on interactions between a diverse natural and highly localized combination of factors of production (climate, soil, water, plant varieties), let alone capital and labour. Furthermore, with the rise of biotechnology the IPR regime became relevant for knowledge creation in the sector. In the following section we explore the changes that the knowledge base in the agricultural sector and its creation has undergone in recent times.

\subsubsection{Globalization and the rise of biotechnology: changes to agricultural innovation}

Agriculture has long been disassociated from technological development (Singer, 1950). This 'non-technological' nature of agriculture, along with the assumption that the sector has little scope for developing backward and forward linkages to

\footnotetext{
12 Tata Motors utilized the engine management system from German firm Bosch, styling and exterior design from Italian firm IDeA, lightweight steering shafts from Sona Koyo, controls for the seating system from American firm Johnson, the engine module from Japanese firm Toyo, heating, ventilating and air conditioning from German firm Behr, tougher tires from Indian firm MRF (Prahalad and Mashelkar, 2010).
} 
other sectors, led to the belief that the sector was a 'dead-end' along the path towards economic growth. The idea accords with Pavitt (1984), who categorized agriculture as 'supplier dominant' 13 which relies on the non-agricultural sector to increase its productivity. Here the major driving force for productivity-enhancing innovations are considered to be similar to what Hirsch-Kreinsenet al., (2005) claim as the key to any low-tech sector namely the ability to configure, adapt, transform, organise and design external knowledge emanating from other sectors. Olmstead and Rhode (2008) in their empirical analysis of US agriculture pay close attention to non-mechanical or biological innovations, in the form of new plant varieties emanating from within the sector. Biological innovations for them include organizational innovation, traditional knowledge and institutional arrangements for creating plant varietal improvement. Their argument is that the success of biological innovations is strongly tied to their adaptation to the biosphere in which they are applied. Hence such innovations are inherently locally embedded and are highly location specific, subject to knowledge-based capital.

The above inference is critical on two accounts. First, it is common knowledge that new plant varieties fail if they are not adapted to local agro-ecology. Further they need to be accompanied by new farming practices. In other words, biological innovation is not simple implementation of scientific knowledge in a new context, but involves identifying the best combination of factors of production that enables higher output for that input.

Second, the knowledge accumulated in development of new plant varieties is often tacit and difficult to appropriate. Large parts of the agricultural knowledge base of this type is embedded over the years in diverse local contexts and institutions (i.e. traditional, community knowledge) in the form of 'routines'. Hence innovation in agriculture follows a particular pattern that involves actors from both the demand and supply sides, creating knowledge that is mainly tacit, locally specific and subject to continuous change, especially due to changes in the agro-ecology.

Several cases confirm this point of view. Bisang (2011) describes how agriculture is an 'open-sky' industry, which transforms selected seeds or animals into a produce according to external environmental resources such as water (rain, irrigation, aquifers etc.), sunlight and cultivated land (constituting nutrients, bacteria, viruses, other living organisms etc.). Katz et al., (2006) demonstrate the high variability

\footnotetext{
13 Pavitt's (1984) typification of agricultural sector as 'supplier dominant' describes the technological activities in agriculture before the biotech revolution i.e. when the application of 'modern biotech' based knowledge to biological innovations in agriculture was still evolving.
} 
and heterogeneity in productivity inherent to aquaculture due to variations in the biosphere.

In sum, productivity in agriculture is highly location specific and, for this reason, it is important to understand that the innovation processes are conceptually different from that of the manufacturing. The scope of adaptation of scientific knowledge to a particular context is much broader and critical. The success of innovation here is determined by the right configuration of global scientific knowledge and local agro-ecological knowledge.

Coming to the nature of actors, investments in agricultural research have been dominated by the public sector (Pardey et al., 2006). The dominance of the public sector in agricultural $R \& D$ is explained by the fact that the R\&D output, plant varieties, are public goods and the $R \& D$ is subject to 'market failures' because plant breeding faces the extreme case of durable-goods monopoly and appropriability problems (Swanson, 2002). Agricultural production is essentially a geographically dispersed activity, carried out in heterogeneous natural resource bases that evolve over time. This condition made investment in knowledge unattractive for the private sector because of high risk and uncertainty, lack of scale effect and appropriability.

The rise of biotechnology and changing IPR in the sector transformed the scenario, however. These changes created the condition in which the 'public-goods' nature of knowledge is diminishing as appropriability of biological innovations is now technically feasible. ${ }^{14}$ Upstream scientific knowledge became scalable as well as replicable via the transfer of genes. This enabled the entry and thriving success of large private firms such as Monsanto, DuPont and Syngenta into agri-biotech R\&D. The rise of biotechnology associated with present-day agriculture, accompanied by a new set of institutions in IPR and provided a different context for actors both private and public to interact in the innovation process.

Large agri-biotech firms (as well as large public sector institutions, for example CGIAR institutions) have a comparative advantage in the global scientific knowledge as compared to domestic firms in the sector because they are more likely to possess the capital for R\&D, have access to highly skilled resources and possess superior organizational capabilities. In this regard, Byerlee and Fischer

${ }^{14}$ Kranthi et al., (2007) note that "World over, GMOs are detected reliably either by detecting DNA segments or specific proteins that are unique to the transgenic crop. DNA detection is primarily through PCR-based methods and protein detection is mainly through immunoassays such as enzyme-linked immunosorbent assay (ELISA) and lateral flow strip methods." 
(2002), while listing the complementary assets (knowledge and non-knowledge) of global and local firms in agri-biotech R\&D, argue that local knowledge, strength of breeding programs and infrastructure, seed delivery system and market network are the assets of local firms, whereas upstream technology know-how, access to capital markets, economies of market size, skills in regulatory nuances and flexibility in decision making are the assets of global firms. They also argue that these assets are complementary for successful innovation, and therefore alliances and $\mathrm{R} \& \mathrm{D}$ collaboration between these players is a natural outcome.

\subsubsection{From knowledge to innovation in agriculture: towards a frame- work}

While the success of agricultural innovation very much depends on global scientific knowledge, complementary in-situ knowledge is needed for localization of technology. This aspect of localization is discussed in detailed in chapter 7. The in-situ knowledge is not only local in nature but also dynamic; that is, changes to the agroecology are frequent, which means that the underlying knowledge base needs constant update. This knowledge can be codified. However the codified knowledge is relevant for only a short period of time. Moreover, physical presence or field data collection is needed to perceive, gather and test the data in order to build and update the knowledge base from time to time. 15

Another type of in-situ knowledge is local market dynamics (elasticity of demand for a certain agricultural output, culture and behavior of the society with respect to a produce, production practices of farmers, and the dominant socio-economic characteristics of consumers). ${ }^{16}$ This type of knowledge is essential for commercial success of an agricultural innovation and exhibits similar characteristics to agroecological knowledge: location specific, dynamic and tacit. Local firms and organizations have a latent advantage in this component because of the proximity to local markets.

The agricultural innovation therefore requires 'upstream knowledge', represented by generic tools, techniques and biological materials (including genes), and 'downstream knowledge', such as locally adaptable plant varieties and practices. An agribiotech firm can therefore innovate upstream for the technology markets while working downstream on incorporating the technologies into new plant varieties. A agri-biotech firm that concentrates on upstream R\&D (a science-based firm) will

15 This way the in-situ knowledge component can be considered as a short-cycle one because of its dynamism in the lines of Lee (2013)

${ }^{16}$ However, the dynamics of this knowledge component are not the focus of analysis in this chapter. 
be selling biotech products, tools, protocols and biological material necessary for developing improved plant varieties (examples include markers that are resistant to antibiotics used in distinguishing the transformed cells from non-transformed plant cells). Therefore there are two major demarcations in the modern agribiotech product markets: (a) generic technology/ products such as genes, biological products, tools and processes; and (b) in-situ technology/products in the form of varieties and practices (Milind et al., 2006, 2007).

With advances in biotech research, the modern-day seed breeders need dynamic catching up with upstream scientific advancements at a global level. Downstream processes in the innovation involving the production of hybrid seeds always hinge on the in-situ component of the knowledge. Combining these arguments, we propose the following characterization of knowledge base:

Global scientific knowledge - molecular biology/genetics (high-end), conventional plant sciences (low-end) - global in nature

In-situ knowledge - agro-ecology: climate, rainfall, soil; local market- local in nature

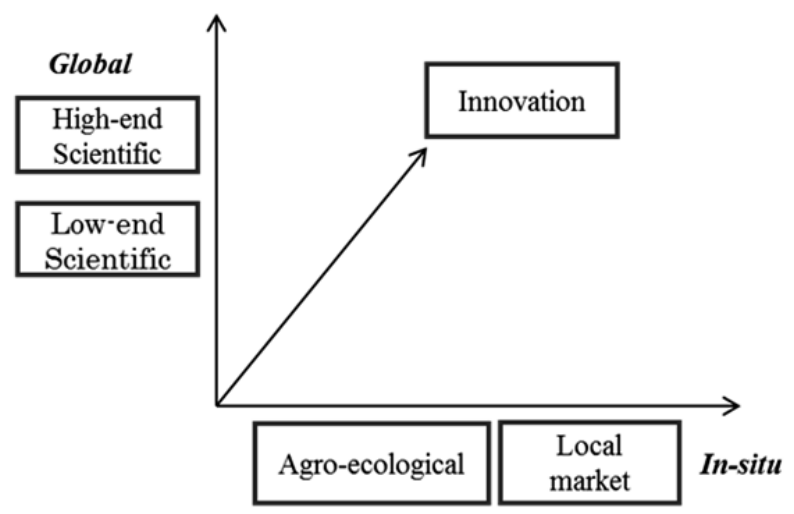

Figure 6.1 Characterization of knowledge base for agricultural innovation

As can be seen from Figure 6.1, the upstream component of knowledge, which is global in nature, has both high-end (genetics, molecular biology) and low-end (traditional plant sciences) components, whereas the in-situ component includes local agro-ecology and market dynamics. The advances in genetics belong to the highend scientific component; whereas the knowledge associated with conventional plant breeding belongs to the low-end scientific component. Similarly, with fastchanging climate and resource degradation, knowledge on the dynamics of local agro-ecology, changing food habits, socio-economic conditions and consumer preferences belong to in-situ knowledge. 
In the section that follows, the catch-up of Indian firms with Bt technology based is analysed based on this general framework. Also analysed is the role of Monsanto, a global technology leader in the catch up process. This way the drawn insights are applicable for both MNEs and local firms.

The case of Bt technology (cotton) in India is chosen for studying the catch- up for the following reasons: (1) the Indian hybrid seeds market has an active presence of both large multinational and medium-small domestic firms; (2) there is a competitive market structure in the hybrid seeds market for commercial crops and vegetables; (3) the dramatic speed of diffusion of Bt cotton hybrids in a decade; (4) the significant benefits observed in the productivity of cotton after the introduction of Bt cotton in India and its impact of overall cotton scenario (see Figure 6.2).

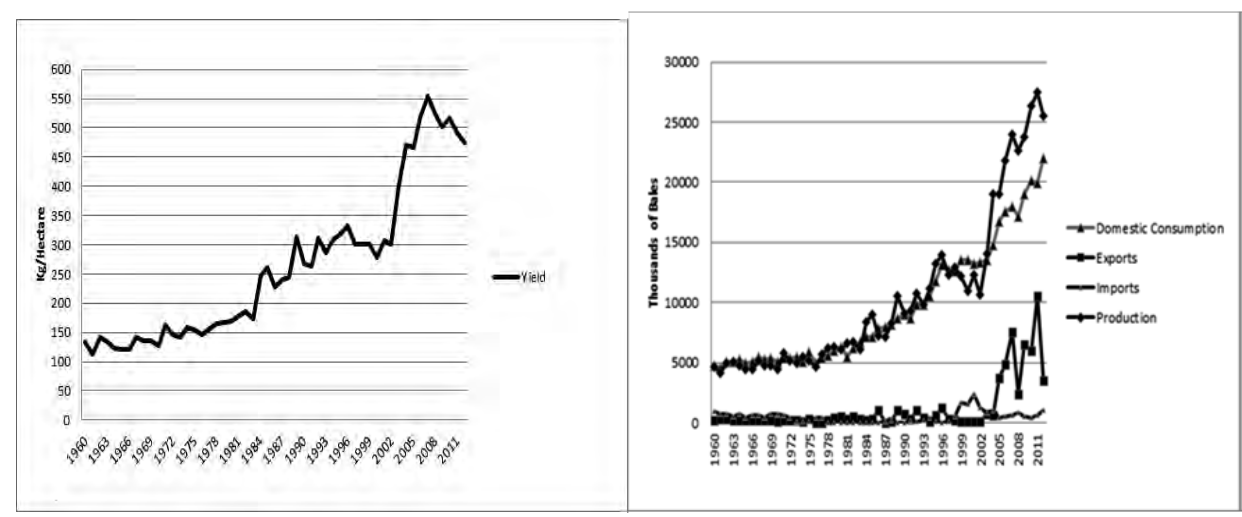

Figure 6.2 India's cotton, left: yield in kg/hectare, right: export and import statistics in bales - 1 bale weighs $226.8 \mathrm{~kg}$ - A jump in the yield and exports is evident from 2002-03. (Source: Production, Supply and Distribution online database of USDA)

\subsection{Catching-up with Bt cotton in India}

The case study that follows draws from secondary data sources as well as insights from the qualitative interviews carried out between Nov 2011 and April 2012 with a range of key informants in Indian agricultural sector. They include economists working on agri-biotech sector, agricultural scientists (public and private sector), marketing and management personnel of Indian seed firms, and representatives of retailers, distributors, and famer groups (see Table A6.2 in appendix).

\subsubsection{Global and Indian seed sectors and the entry of Bt cotton into India}

The global commercial seed market is worth $\$ 42$ billion and, out of this, the global biotech seed market is estimated to account for $\$ 13.2$ billion (ISC, 2013). The global seed industry is highly concentrated. The increasing concentration in the global seeds market is evident from the share of the top ten companies increasing from 
$40 \%$ in 2001 to $75 \%$ in 2011 . The top ten firms in the global seed markets are given in Table 6.2 .

Table 6.2 Top firms in the global seed market in 2011

\begin{tabular}{lll}
\hline Rank & Firm & \% of Global seed market share \\
\hline 1 & Monsanto (USA) & 26.0 \\
2 & DuPont Pioneer (USA) & 18.2 \\
3 & Syngenta (Switzerland) & 9.2 \\
4 & Vilmorin (GroupeLimagrain) (France) & 4.8 \\
5 & WinField (Land O Lakes) (USA) & 3.9 \\
6 & KWS (Germany) & 3.6 \\
7 & Bayer Crop science (Germany) & 3.3 \\
8 & Dow Agro Sciences (USA) & 3.1 \\
9 & Sakata (Japan) & 1.6 \\
10 & Takii\& Company (Japan) & 1.6 \\
\hline
\end{tabular}

Adapted from ETC-Group (2013)

The top three firms, Monsanto, DuPont and Syngenta, account for 53 percent of the world's commercial seed market (ETC-Group, 2013b). Also, the same top three companies accounted for $72 \%$ of utility patent applications in plant varieties and $44 \%$ of applications for plant variety protection certificate. These statistics indicate the leadership of MNEs in both the upstream technology market and in the downstream seeds market. While the markets for technology (agri-biotech tools and products) and seeds (transgenic and non-transgenic hybrids) combined constitute the agri-biotech market, the increasing concentration is a result of mergers and acquisitions and cross-licensing between major firms, primarily driven by the need to stay ahead in agri-biotech market. Agri-biotech innovations by and large include molecular markers and related tools, gene constructs/events, development/ regeneration protocols and transgenic and non-transgenic hybrids.

India has the second-largest arable land area, after the US, accounting for $11.4 \%$ of world's total arable land (UNFAO, 2015b). As a consequence the Indian commercial seed market is the sixth largest after the US, China, France, Brazil and Canada (ISF-Website, 2013)

From the early 1970s to the early 1990s, much of agricultural R\&D in India had been carried out by the public sector (Indian Council for Agricultural Research: ICAR). During this period the private seed breeders benefited a great deal from the spillover from the public sector (Pray et al., 2001). Following the introduction of a liberal seed policy in 1988, which allowed for the importing of seed and planting materials of top varieties to make them available to Indian farmers, private sector investments in the seed sector have steadily increased from INR 417 million in 1987 to INR 6000 million in 2009 (Pray et al., 2001; Murugkar et al., 2006). This was accompanied by an increase in R\&D investment, which rose from US $\$ 1.3$ million (2005 US\$) in 1984-85 to US\$49.3 million (2005 US\$)(Pray and Nagarajan, 
2012). More recently the introduction of the Protection of Plant Varieties and Farmers' Rights Act, 2001 (PPV \& FR Act) which is India's sui generis of UPOV, further boosted the private sector's confidence in the appropriability of innovations. Today, while the public sector institutions concentrate on open pollinated varieties (OPVs) in grains, pulses and oil seeds, private firms are by and large engaged in the high-value hybrids in cotton, sunflower, maize and vegetables.

With the increasing uptake of hybrids by the farmers in cash crops and vegetables, between 1995 and 2004 the Indian seed market grew from US\$ 1538 million to US\$ 5336 million (Pray and Nagarajan, 2014). It has also grown to become an increasingly competitive market, with numerous local firms and MNEs competing in cotton, corn and vegetable segments. While Monsanto, Syngenta, DuPont Pioneer, Bayer Crop Sciences among other MNEs have their presence in the Indian hybrids market, the prominent domestic seed firms include Nuziveedu Seeds, Rasi Seeds and Mahyco among others. As of 2011, Nuziveedu has the largest share in the Indian hybrid seed market (23\%), out of which Bt cotton hybrids make the largest contribution.

Table 6.2 gives a list of top agri-biotech firms in the India. The rankings to a large extent are reflective of the firm performance in Bt cotton. Bt cotton market is an emerging one and there are no firm specific data available in public domain that enables a comparison of firms. Hence the chapter relied on data/information from the 'Bio-Agri' segment of ABLE-Biospectrum biotech industry survey. The Bio-Agri segment includes firm performance in GM seeds (Bt cotton), molecular markers and related products. It does not include other hybrids. The sale of Bt cotton hybrids clearly dictates the revenues in this segment.

Table 6.2 Top agri-biotech firms operating in India

\begin{tabular}{lllll}
\hline & & \multicolumn{3}{l}{ Revenues in US\$ million (INR 60.5= US\$ 1) } \\
\hline Ranking & Firm & $2011-12$ & $2010-11$ & $2009-10$ \\
\hline 1 & Nuziveedu Seeds & 123.18 & 100.86 & 78.85 \\
2 & Rasi Seeds & 64.81 & 61.49 & 59.32 \\
4 & Ankur Seeds & 53.74 & 41.34 & 18.11 \\
5 & Mahyco & 51.92 & 59.36 & 51.59 \\
6 & Krishidhan Seeds & 28.74 & 45.66 & 22.03 \\
7 & Nath Seeds & 14.88 & 4.55 & 3.65 \\
8 & JK Agri Genetics & 8.38 & 5.32 & 5.37 \\
9 & Mavens Biotech & 7.53 & 9.28 & 7.86 \\
10 & Excel Industries & 1.81 & 2.01 & 1.36 \\
\hline
\end{tabular}

Source: Compiled from ABLE-Biospectrum Biotech Industry survey 
As pointed out elsewhere, India has the largest cotton-growing area in the world (apx. 12 million hectares). Cotton is an important cash crop that constitutes about $60 \%$ of the total share of hybrid seeds segment in the Indian seed market (ISC, 2013). R\&D and innovation in the cotton hybrids is dominated by the private sector (see Table 6.3).

Table 6.3 Hybrids in selected field crops by public and private sector in India

\begin{tabular}{llllllll}
\hline Crop & Up to 2001-02 & 2002-03 to 2009-10 & Total & & $\begin{array}{l}\text { Share of private } \\
\text { sector hybrids } \\
\text { (\%) }\end{array}$ \\
\hline & & & & & & & \\
Cotton* & Private & Public & Private & Public & Private & Public & \\
Maize & 150 & 15 & 43 & 10 & 193 & 25 & 88.5 \\
Paddy & 67 & 3 & 36 & 25 & 103 & 28 & 78.6 \\
Wheat & 12 & 4 & 11 & 15 & 23 & 19 & 54.8 \\
Pearl millet & - & - & 3 & 0 & 3 & 0 & 100 \\
Sorghum & 41 & 6 & 22 & 7 & 82 & 13 & 86.3 \\
Sunflower & 35 & 6 & 12 & 8 & 53 & 13 & 80.3 \\
\hline
\end{tabular}

Adapted from Singh and Chand (2011)

However by the start of the new millennium, cotton suffered from lower yields due to pests and low yielding varieties. On the demand side, low uptake of hybrids and low-performing open pollinated varieties (OPVs) were causing distress among cotton farmers. On the supply side, by 2001-02 (Singh and Chand, 2011) the private seed firms that were active in cotton R\&D commercialized 150 hybrids, whereas the public sector released 15 hybrids. Nevertheless, farmers were facing yield losses and rising costs due to pests. In these circumstances, Mahyco, while partnering with the multinational Monsanto, introduced in 2002 the first ever insect-resistant Bt cotton under the brand name of Bollgard.

Monsanto licensed its gene Cry1A to Mahyco, which in turn incorporated the gene into its hybrid line MECH 1. Bollgard was approved for commercial release by GEAC ${ }^{17}$ in two phases: first in 2002 for the central and southern zones, followed by its approval for the northern zone in 2005. With the commercial success of Bollgard the demand for Bt cotton hybrids increased rapidly (Murugkar et al., 2007).

\footnotetext{
${ }^{17}$ The release of transgenic crops in India is regulated under the Indian Environment Protection Act, 1986. India's biosafety regime towards GMOs was setup as early as 1989 followed by the setup of a network of implementing agencies such as Institutional Biosafety Committee (IBSC), Review Committee on Genetic Manipulation (RCGM), Genetic Engineering Approval Committee (GEAC). At an international level, India ratified the Cartagena Protocol on biosafety in 2003. Subsequently a national authority on biosafety, a biosafety clearing house and a reporting mechanism were setup. These regulatory measures paved the way for the entry and diffusion of Bt cotton in India also facilitating the technological catch up. However, in this chapter, the focus is on the firm level strategies in the catch-up story.
} 
Between 2004 and 2013 the planted area of Bt cotton rose to approximately 95\% of the total cotton area planted. Local firms wanted to take advantage of this growing demand. While a majority of local firms chose to license the Bt genes (event MON531) from Monsanto and Mahyco Biotech (MMB), a 50:50 joint venture of Monsanto and Mahyco to incorporate the technology into their own cotton hybrids, few chose to develop their own Bt technology.

At an industry level, with the advent of Bt technology, the number of local firms engaged in agri-biotech R\&D has increased. By 2013 about 64 agri-biotech firms were doing R\&D in GM seeds. Among these 64 firms, 37 engage in the sale of Bt cotton hybrids (IGMORIS, 2014). At a sectoral level, the agri-biotech industry saw a healthy growth in the last decade, with the growth coming mainly from the sale of Bt cotton hybrids (see Figure 6.3).

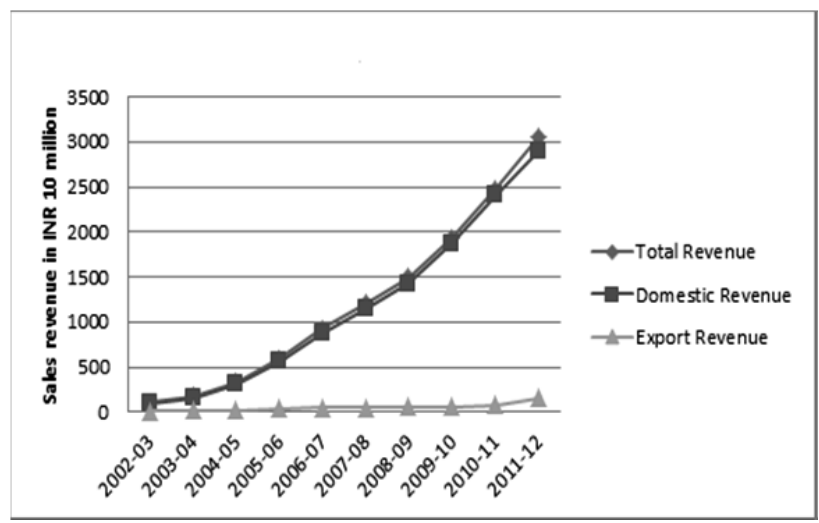

Figure 6.3 Growth of Agri-biotech industry in India (GM seeds, molecular markers and related products only). Source: Compiled from ABLE-Biospectrum Biotech industry surveys 2002-2012.

\subsubsection{The science behind Bt cotton and the possibility of stage skipping}

From the supply side of innovations, introduction of genetic engineering techniques has ushered in a new era in seed technologies. The scientific advances in molecular biology, genomics, proteomics and the introduction of techniques such as polymer chain reaction, recombinant DNA methods and marker-assisted breeding have enabled the development of GM crops with desirable traits.

The development of a GM plant variety involves 5 major technical steps, Isolation of the gene of interest, Gene transfer, Regeneration, Hybridization for agronomic fit, and Regulatory testing (see Table A6.1 in the Appendix for detailed explanation). The new genetic engineering techniques enable the scientists to break down the innovation/production processes into steps, where different actors can manage each step. The emergence of these techniques took place against the backdrop 
of globalization of the production system where the production process is broken down into segments along the global production chain connecting actors at global as well as local levels. In such a context, local actors with a sufficient knowledge base, technological efforts and absorptive capacity are considered to play an increasingly critical role in the localization process. This is also true in the case of agricultural innovation especially in the development of new GM plant varieties.

Both global and local players entered the GM cotton market in this new context of production segmentation, with strategic options for knowledge acquisition and learning. For instance, firms were able to choose strategically from the following options: whether, first, to develop the GM seed from scratch, that is, start with the identification of source genetic material and work from there; and, second, to skip the initial stages of development (isolation, transfer and regeneration); or to license a commercially approved event (the genetic materials with favorable traits that are transferred to the plant) for backcrossing into their elite parental lines.

The occurrence of a genetic material in the cell structure of a target plant that exhibits the desired traits is usually termed an 'event'. Events are usually IP protected and are licensed to the hybrid seed producers for backcrossing into their elite cultivars. Back-crossing is a technique used in plant breeding to introduce a desirable gene into a cultivated variety. The cultivated variety (the recurrent parent) is crossed with the donor parent, which may be quite useless agronomically except for its possession of one particularly valued gene (e.g. Bt genes for insect-resistance). The crossing continues in multiple stages until the plants with desired traits occur.

As far as Indian seed firms are concerned, their strategic choices were as follows: they could choose to stay in conventional hybridization of seeds or to engage in implementing biotechnology techniques; if they decide to do the latter, they have to decide on how to obtain or build technological capabilities. They can do this via in-house efforts, licensing, joint venture/ alliances (in collaboration with MNEs, domestic firms or the public sector entities).

Since both scientific and in-situ knowledge are essential to create high-performing seeds, a majority of domestic firms strategized to leverage their in-situ knowledge base while accessing upstream knowledge from global partners.

\subsubsection{Strategies played by firms in the technology market}

Monsanto created a 50:50 venture firm MMB (Mahyco Monsanto Biotech) in collaboration with a local firm, Mahyco (Maharashtra Hybrid Seeds Corporation) in order to diffuse its Bt gene/event MON531 in the growing Indian hybrids market. Mahyco introduced India's first Bt hybrid cotton called Bollgard, which incorporated Monsanto's MON531. 
Other Indian firms reacted to the rapid success of Bollgard and, given the untapped market of Bt cotton hybrids, started sublicensing MMB's event MON531. In 2006, JK Agri Genetics, which started in 1989 with high-yielding varieties in field crops and moved to cotton hybrids, developed a Bt event called event I (Cry1Ac gene) in collaboration with BREF- Biotech of the Indian Institute of Technology, Kharaghpur. In the same year, Monsanto introduced its stacked gene event MON15985 (a stacked gene is a combination of genes Cry1Ac+Cry2Ab of Bt) followed by Nath Seeds (a local seed firm established in 1979) introducing its GFM event. Nath seeds initially licensed the Cry1Ac gene from the Chinese Academy of Sciences and further developed its own stacked gene event.

In 2008, purely public sector institutions Central Institute for Cotton Research (CICR) and University of Agricultural Sciences, Dharwad (UAS Dharwad) obtained commercial approval of their indigenously developed event Truncated Cry1Ac (along with the hybrids and open pollinated varieties) based on this event. ${ }^{18}$ Later in the year 2009, Metahelix Life Sciences obtained commercial approval for its indigenously developed Cry1C event Metahelix 9124. A list of approved events by the genetic engineering appraisal committee of India is given in Table 6.3. By May 2012, six GM events and more than 1128 Bt cotton hybrids (based on the six events) gained permission to be planted across the three agro-ecological cotton zones $^{19}$ of India (GEAC, 2013).

Table 6.3 Bt events with commercial approval in India as of May 2012.

\begin{tabular}{|c|c|c|c|c|}
\hline Year & Firm; Genes; Event & Type of firm & $\begin{array}{l}\text { Strategy for develop- } \\
\text { ing Bt technology }\end{array}$ & $\begin{array}{l}\text {-Collaboration Strate- } \\
\text { gy }\end{array}$ \\
\hline 2002 & Monsanto; Cry1Ac; MON 531 & Multinational & In-house R\&D & None \\
\hline 2006 & $\begin{array}{l}\text { JK Agri Genetics; indigenously } \\
\text { developed Cry1Ac; Event I }\end{array}$ & Local & $\begin{array}{l}\text { R\&D in alliance with } \\
\text { IIT, Kharaghpur }\end{array}$ & $\begin{array}{l}\text { Collaboration with } \\
\text { public sector players }\end{array}$ \\
\hline 2006 & Nath Seeds; Cry1Ac+Cry1Ab; GFM & Local & $\begin{array}{l}\text { Licensing from } \\
\text { Chinese Academy of } \\
\text { Sciences }\end{array}$ & $\begin{array}{l}\text { Indigenous develop- } \\
\text { ment from licensed } \\
\text { technology }\end{array}$ \\
\hline 2006 & $\begin{array}{l}\text { Monsanto; Cry1Ac+Cry2Ab; MON } \\
15985\end{array}$ & Multinational & In-house R\&D & None \\
\hline 2008 & $\begin{array}{l}\text { UAS Dharwad and CICR; Truncated } \\
\text { Cry1Ac; BNLA } 601\end{array}$ & Public sector & In-house R\&D & $\begin{array}{l}\text { Collaboration be- } \\
\text { tween public sector } \\
\text { institutions }\end{array}$ \\
\hline 2009 & Metahelix 9124; Cry1C; MLS9124 & Local & In-house R\&D & None \\
\hline
\end{tabular}

Compilation from GEAC (2013) and Choudhary and Gaur (2010).

18 The approval of this event is subject to controversy as traces of contamination (from Monsanto's event) seem to have appeared in its gene construct. http://www.thehindu.com/todays-paper/tpnational/panel-finds-lapses-in-development-of-first-indigenous-bt-cotton/article4215389.ece.

${ }^{19}$ North: Punjab, Rajasthan, Haryana; Central: Gujarat, Madhya Pradesh, Maharashtra; South: Andhra Pradesh, Karnataka, Tamil Nadu. 
It is interesting to note that Metahelix is the only local firm that developed its GM event via in-house R\&D, while the majority of local firms opted to collaborate with other firms for accessing knowledge. Re-engineering of existing commercial genes by local firms played a crucial role in the development of Bt genes. ${ }^{20}$ Since a large proportion of upstream knowledge is codified and transferable, re-engineering was plausible. Figure 6.2 shows firms' performance in the technology market (Bt events) as the number of approved hybrids year wise based on their events as well as the growth in the number of hybrids based on specific gene-constructs.

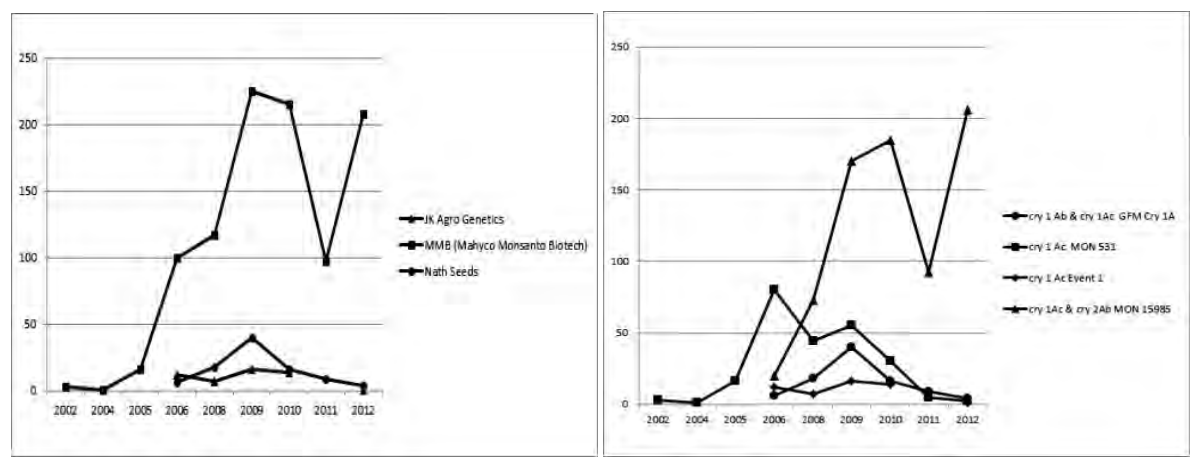

Figure 6.2 Left: Firms' performance in the technology market (Bt events) as the number of approved hybrids, approved year on year, based on their events. Right: Annual growth of eventspecific (gene-specific) cotton hybrids in India. Source: Compiled from GEAC (2013)

\subsubsection{Strategies played by Indian firms in developing the Bt hybrid seeds}

With the initial success of the technology and the hybrids incorporating the technology, domestic firms have significantly increased their investment in Bt cotton to acquire the technology in various ways. The initial market success of Mahyco's Bollgard prompted local firms to sublicense MMB's event MON531 and incorporate it into their best-performing hybrids. As a result, MMB enjoyed first-comer advantage in the technology market in India. Currently, MMB dominates the market for technology (via sublicensing of the single and stacked gene events to local firms). In fact, 982 out of 1128 commercially approved Bt cotton hybrid seeds in India use Monsanto's events (see Figure 6.2).

${ }^{20}$ By JK Agri Genetics and Nath Seeds, excerpt from the focus group discussion on 'Status of Bt cotton R\&D in India', held in December 2011, Agri Biotech Foundation India, Hyderabad, India. 


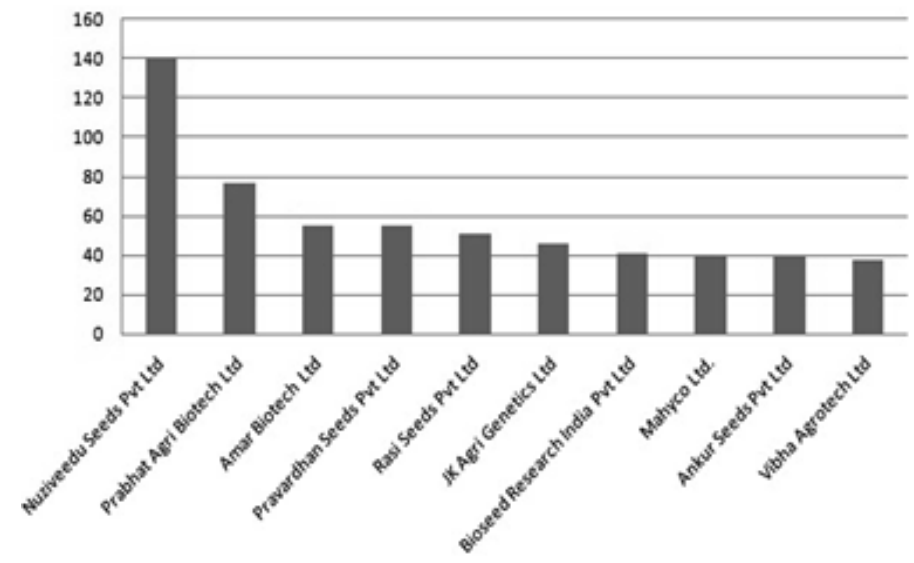

Figure 6.3 Indian firms and the total number of Bt cotton hybrids commercialized by them by the year 2012. Source: Compiled from GEAC (2013)

While the technology (event) market is dominated by MMB, the hybrid seeds market is dominated by local firms, including Nuziveedu Seeds, Rasi Seeds and Mahyco (see Table 6.4 and Figure 6.3). The local seed firms enjoyed almost $100 \%$ of the market share by 2008 . As early as 2000 , the Indian seed firms developed the insitu knowledge base that is critical for verifying the agronomic fit of the hybrids with the local agro-ecology (Pray and Nagarajan, 2014). In fact Nuziveedu Seeds enjoyed market leadership in non-Bt or conventional cotton hybrids that were developed in-house years before the entry of Bt technology into India. By sublicensing the Bt event from MMB, Nuziveedu then introduced the Bt versions of the same hybrids. Thus, to utilize the existing competence, in terms of both the in-situ knowledge base and expertise in developing conventional hybrid seed, a majority of local firms including Nuziveedu chose to sublicense MMB's gene to successfully integrate the 'generic' and 'high-end scientific' knowledge into their bestperforming hybrids by backcrossing.

Table 6.4 Leading local firms in the Bt cotton market in India

\begin{tabular}{llll}
\hline Rank Firm & Strategy for developing Bt cotton hybrids & $\begin{array}{l}\text { Revenues in 2012- } \\
13 \\
\text { (INR million) }\end{array}$ \\
\hline 1 & Nuziveedu Seeds & $\begin{array}{l}\text { Sub-licensing and in-house back crossing; Mergers } \\
\text { \&Acquisitions }\end{array}$ & 7781.3 \\
2 & Ankur Seeds & Sub-licensing and in-house back crossing. \\
3 & Mahyco & Licensing and in-house back crossing; Alliance with & 2460.0 \\
& & MNE. & \\
4 & Rasi Seeds & Sub-licensing and in-house back crossing. & 2290.0 \\
5 & Krishidhan Seeds & Sub-licensing and in-house back crossing. & 1998.1 \\
\hline
\end{tabular}

Source: Compiled from ABLE-Biospectrum Biotech Industry Survey, 2013. 


\subsubsection{Applying the framework}

A diverse spectrum of strategies followed by key players in the Bt technology market (events) is shown in Table 6.3. Domestic firms such as JK Agri Genetics developed their event based on the gene Cry1Ac in collaboration with a public institution, BREF Biotech of the Indian Institute of Technology, Kharaghpur. On the other hand, Metahelix Life Sciences developed its Bt event based on the gene Cry1C via in-house R\&D. Nath Seeds developed a new event of stacked genes, a combination of two genes, Cry1Ac and Cry1Ab, after licensing the single gene event based on Cry1Ac from the Chinese Academy of Sciences. It is interesting to note that a majority of local firms were able to produce Bt genes/events by acquiring generic knowledge via licensing or forming alliances with other actors. The exception is Metahelix life sciences, which developed its Bt event via in-house R\&D.

The strategies taken by firms in catching up with the upstream as well as downstream knowledge components demonstrate the diversity in available pathways (see Figure 6.4). At the same time there are common features across the firms' strategies that bring out the complementary of upstream and downstream knowledge for successful outcomes. Indeed, the diverse strategies to access upstream knowledge are observed as follows: (a) alliance for R\&D (Nath Seeds, JK Agri Genetics); (b) licensing (a majority of local seed firms); (c) in-house R\&D (Metahelix life sciences) and (d) joint venture (MMB by Mahyco and Monsanto) (e) M\&As (Nuziveedu). A majority of the firms acquired the technology through collaborating with external actors, enabling them either to 'skip' some development steps or to 'create' new combinations of development.

Similar strategies are applied for building downstream knowledge. These were applied for producing quality seeds and in scale, the strategies are: (a) backcrossing of Bt events into hybrid lines developed in-house and (b) Mergers \& Acquisitions to expand the hybrid lines. 


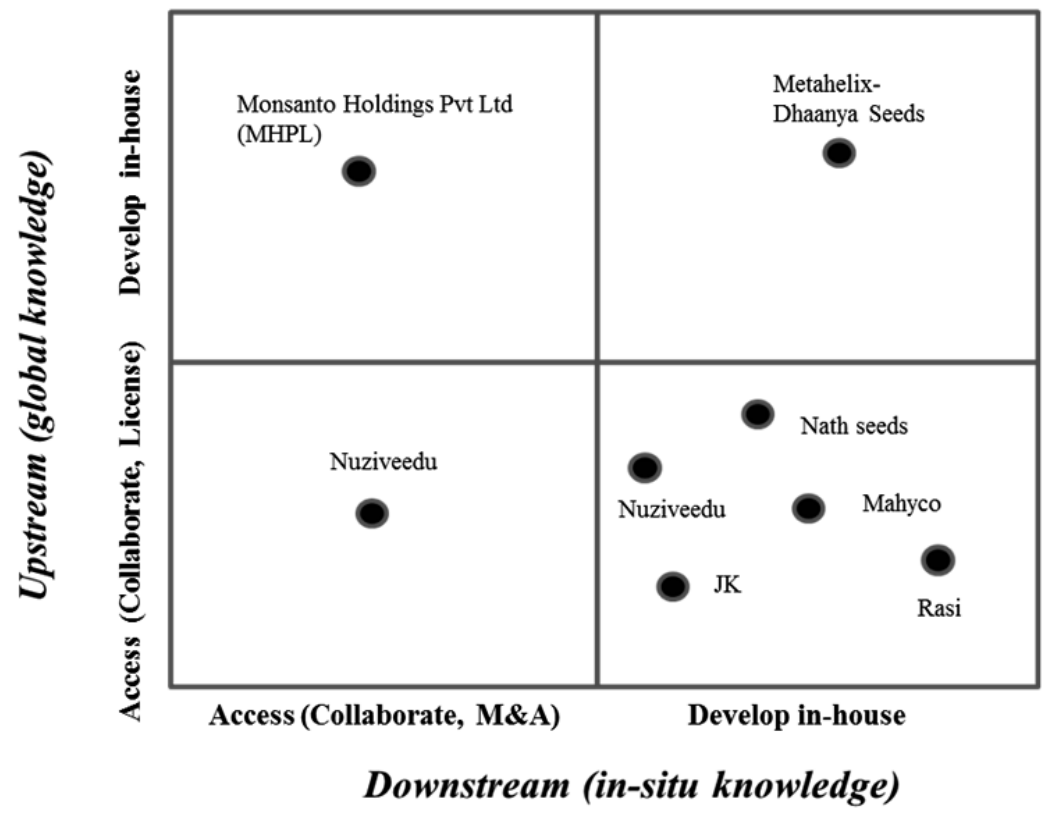

Figure 6.4 Mapping of firm strategies to catch up with Bt cotton hybrids

As can be seen in Figure 6.4, the strategies adopted for catching up with upstream and downstream components by local firms as well as Monsanto can be mapped onto the matrix ${ }^{21}$. Also the two pathways collaboration or developing in-house of these knowledge components can be traced for all the firms involved in the development and commercialization of Bt cotton hybrids. For instance Nuziveedu seeds applied the collaboration strategy for acquisition of technology (upstream) whereas it backcrossed the acquired technology into commercially successful hybrids developed both in-house (Banni and Mallika) or those acquired through M\&As. Metahelix developed its Bt cotton hybrids based on in-house efforts.

If we apply the catch up typologies put forth by Lee and Lim (2001) - path following, stage skipping and path creating to the case of Bt cotton, it is evident that a

\footnotetext{
${ }^{21}$ Given the complexity involved in mapping the strategies of all Bt cotton seed firms in India, only the strategies of few important firms are mapped. However, all firm strategies fit well into one of the regions of the matrix. MMB (Mahyco Monsanto Biotech) does not appear in the matrix since it does not (on its own) produce or market any Bt cotton hybrids. MMB sub-licenses Monsanto's events to local firms. Nuziveedu falls in two regions as it developed its Bt cotton hybrids from its own basket of hybrids as well as from the hybrid lines of acquired local firms.
} 
majority of firms adopted a stage-skipping strategy. This dominant strategy nevertheless requires well-established conventional plant-breeding capabilities and absorptive capacity for back-crossing and verification of agronomic fitness. This means that only firms with established low-end scientific capabilities (hybridization and knowledge of biotech techniques) and in-situ knowledge base (local climate, soil conditions and market) can adopt the stage-skipping strategy. The rapid diffusion of Bt technology also meant the rapid scaling up of local firms in certain facets of upstream biotech techniques required for regulatory approval as well as competitive success.

Though a majority of local seed firms adopted the stage-skipping strategy, few firms adopted the path-following pattern. For instance, JK Agri Genetics developed its event based on Cry1Ac in collaboration with a public institution BREF Biotech, of IIT Kharaghpur, from which it developed its own Bt hybrids. Metahelix Life Sciences, on the other hand, developed an event based on the gene Cry1C via in-house R\&D which shows that it chose to create its own pathway. Nath Seeds adopted a similar 'path-creating' strategy by placing on the market its hybrids based on stacked genes (a combination of two genes, Cry1Ac and Cry1Ab) developed in collaboration with the Chinese Academy of Sciences.

The catch up story of Indian firms in Bt technology therefore illustrates a spectrum of patterns as illustrated by Lim and Lee (2001). Moreover, the presence of diverse pathways for catching up became evident. The successful Indian firms with Bt technology are the ones which moved beyond obtaining Bt technology from MNEs. For seeds to carry good agronomic features, the firms needed to have technological capabilities to either re-engineer or incorporate the technology into their hybrids. That is the local firms' strength in low-end scientific and in-situ knowledge base played a critical role in the catch up.

Monsanto, being a large multinational, has its strengths in the upstream (biotech) knowledge for developing the events, while Indian firms, such as Nuziveedu Seeds, Mahyco and Rasi Seeds, among others, are strong in the downstream knowledge and capabilities for creating viable hybrids for distinctive agro-ecological zones in India. Even though Monsanto had advanced technological capability, creation of good-quality hybrid seeds needs knowledge of successfully adapting innovations to the local agro-ecology. The alliance of Mahyco and Monsanto was therefore a natural outcome. Also such collaboration was a sine qua non for Monsanto to penetrate into the Indian market.

The limitation of Monsanto's capability to dominate the seeds market on its own despite its strength in upstream scientific knowledge also became evident. MHPL (Monsanto Holdings Private Limited), which markets Paras Brahma Bt hybrids 
developed by Monsanto's own subsidiary, has lost competitive ground in the Indian market to the hybrids of other local firms including Mahyco. In fact, the Indian firm Nuziveedu Seeds has the highest market share in India, while Bt cotton hybrids were created based on a sublicensed technology from Monsanto Mahyco Biotech (MMB).

Nuziveedu Seeds, established in 1973, had 'Bunny' and 'Mallika' brands of its conventional cotton hybrids performing well in the markets by the late 1990's. Their efforts in developing conventional hybrids started to pay off with the entry of Bt technology as the 'Bt' versions of Banni and Mallika propelled Nuziveedu into the top spot in the Bt cotton market. Moreover, in order to diversify its hybrid lines Nuziveedu acquired local firms Yaaganti Seeds, Pravardhan Seeds in 2010 and Prabhat Agri Biotech in 2011. The two different strategies of Nuziveedu (Licensing and Acquisitions) are mapped in Figure 6.4.

Another local firm, JK Agri Genetics, established in 1989, had its basic R\&D centre up and running by 1997. By 1999 it expanded its R\&D to conduct biotech research. JK had its conventional cotton hybrids developed in-house launched as early as 1999 and in 2006 it commercialized Bt cotton based on its own event. Rasi Seeds, another major player in Bt cotton (established in 1973) started transforming its R\&D capabilities as early as 1986 and launched its first conventional cotton hybrid RCH 2 in 1992, whose Bt variant is still popular in the market.

The comparison of Monsanto (standing on its own as Monsanto Holdings Private Limited - MHPL's - particularly their Paras Brahma hybrids) with local firms reveals that the local firms are able to compete with Monsanto in Indian Bt cotton market despite gaps in the upstream knowledge. Given the variable agro-ecological conditions that exist in the vast cotton-growing zones in India the local firms were able to strategically leverage their strengths in the in-situ knowledge to develop market competence.

At a broader level, the strategies played by the Indian seed firms confirm the transformation of the agricultural innovation process, the diversity of pathways in catching up via integration of external and internal knowledge, through various means of collaboration such as licensing, joint ventures with MNEs, M\&As of local firms and forming R\&D alliances with public sector entities. Moreover, the catching-up process of Indian firms in Bt technology demonstrated the three patterns of catching-up as specified by Lim and Lee (2001) as firms' strategic choices. More importantly, the case validates our characterization of the knowledge involved in modern day agricultural innovation. 
We see that, with the paradigm shift in the technology (agri-biotechnology with its genetic engineering techniques) new opportunities arose for local firms to catch up as they became part of a global production chain. Fragmentation of knowledge creation along the value chain and improved access to knowledge via the IPR system allowed domestic firms with high levels of absorptive capacity to catch up quickly. Local firms with established competence in the in-situ knowledge were able to catch up quickly and compete in the cotton seeds market. The knowledge gaps for local firms as well as foreign multinationals are being bridged via technology transfers, joint ventures and M\&A's to increase returns from upstream technology as well as downstream seed markets.

In sum, it is evident from the analysis of the diffusion of Bt technology in India that global-upstream and local-downstream knowledge are complementary, and joint efforts for vertical integration are critical for successful outcomes in the agribiotech industry. Furthermore, the case demonstrates that, even though collaborative efforts are necessary at the global-local level, there are various routes which firms can take to reach the ultimate goal of catching-up with frontier technologies. While diverse pathways can be followed by the local firms to catch-up, firms with the ability to efficiently integrate location-specific (in-situ knowledge) and global (generic scientific knowledge) were able to successfully catch-up and compete in the domestic markets.

\subsection{Discussion and conclusion}

In this chapter, the dynamics of knowledge creation and diffusion and the role of firms in the emerging country seed sector are analysed. The literature review showed that the knowledge creation process is now more collaborative and is shaped by distinct configuration of networks that each entity has. The global integration of production and innovation implies that knowledge is being shaped by interaction among global and local actors. Here, the rise of new technology paradigms such as biotechnology followed by the new set of IPRs influence the diverse ways in which knowledge is accessed and configured for potential market gains. At the same time, in an era of globalization while knowledge is increasingly accessible, in principle, to the wider population, studies focusing on the manufacturing sector have indicated that developing indigenous capabilities that enable appropriate selection and utilization of external knowledge is critical. A striking analogy in the case Bt cotton in India, but with its own peculiarities is observed.

While agricultural production, which relies heavily on agro-ecological conditions remains unchanged, the rise of biotechnology has altered the conventional scientific approach for finding solutions for better yields. The case of Indian Bt cotton has clearly highlighted such changes. Today, the process of agricultural innovation is strongly punctuated by biotech $\mathrm{R} \& \mathrm{D}$, which is configured in distinctive ways. 
Each firm can choose from diverse strategies, considering its strength in the knowledge base constituted by global and in-situ components, to identify its preferred areas of investment. The sectoral specificity, the underlying technology, and the differences in capabilities have presented diverse pathways of catch-up for firms within a country, within a sector and within a product market.

The firms learning and access to foreign know-how played a major role in the catch-up process as pointed out by Malerba and Nelson (2011). The technological capabilities (low-end) of local firms are evident from the commercial success of their conventional hybrids. Besides these factors, identifying the right strategy to combine external and internal knowledge to develop Bt hybrids became critical for market success. Also the analysis brought out the role of supply (of technologies), domestic demand and the development of vertical linkages between agri-biotech and seed firms in the catch-up process. The complementarity between the upstream and downstream knowledge components was evident and that the knowledge flow can be bi-directional or circular, with global-local interactions between leaders of in-situ knowledge and leaders of global scientific knowledge is established.

Earlier works on catching up and technological leapfrogging (Soete, 1985; Perez and Soete, 1988) discuss the emergence of 'windows of opportunity' for catching up countries. The entry cost of this 'window' that appears during major technological transitions and is considered lower at an early stage of the transition. However, the follower countries or firms have to build technological capabilities to overcome the barriers to entry. As evident from our case, in the case of agricultural technologies firms in follower countries have a clear advantage in the in-situ knowledge base that plays a critical role in the catch up. More specifically, the initial costs of entry for building upstream 'technological' capabilities for Bt cotton were significantly reduced by the possibility of stage-skipping (licensing of genes) and the cumulative efforts put up by the local firms to absorb and adapt the externally acquired knowledge. At the same time, complementarity of the two types of knowledge, global and in-situ was strategically leveraged via collaborations. These peculiarities mark a clear difference between the catch up process in Bt cotton and cases of catch up in other sectors.

Finally, the analysis of this catch up story has the following limitations. First, cotton is a cash crop and not a food crop; hence the generalization cannot be freely extended to innovations in food crops, which can have different dynamics in the agricultural markets of emerging countries. In similar lines OPVs, non-transgenic hybrids and other cash crops may encompass different catch up dynamics. Also it is difficult to draw parallels with other country and seed industry contexts as the industry structure, knowledge base, local market demand and institutions vary. 


\section{Appendix}

\section{Table A6.1 Major technological steps involved in the development of a GM plant variety}

1 The isolation of the gene of interest responsible for a desired trait, i.e. insect resistance in the case of Bt from the source (micro-organism).

2. The gene of interest is then inserted into the native DNA of a vector (usually a soil bacterium called Agro-bacterium Tumefaciens); the process is popularly known as agro-bacterium-facilitated gene transfer.

3. The vector is then used as a means to transfer the desired genetic material into the target plant cells (alternative non-vector methods include gene transfer via a gene gun, micro injection).

4. The plant cells that took up the gene of interest are carefully selected for regeneration of the whole plant. Plant regeneration usually involves the methods of tissue culture or biotech breeding procedures.

5. The regeneration process is followed by the verification of the new plant characteristics for desired traits.

6. Laboratory and greenhouse-level environmental and biosafety tests are carried out.

7. The desired plant is then crossed with a local cultivar that has proven superior agronomic performance (usually by backcrossing).

8. All the desired genetic characteristics (both superior agronomic performance and GM traits) thus finally appear in the next generation plants.

9. Performance testing, environmental and biosafety tests are further carried out in field settings for obtaining commercial approval from the regulatory agency.

Table A6.2 List of interviewees (interviews conducted between Nov 2011 and April 2012)

\begin{tabular}{|c|c|}
\hline No. & Role \\
\hline Interviewee 1 & Agricultural scientist working on sustainable technologies \\
\hline Interviewee 2 & Chief scientist - Plant Biotechnology - Domestic seed firm. \\
\hline Interviewee 3 & Director and Professor in Plant Physiology \\
\hline Interviewee 4 & Economist specialized in Bt cotton in India \\
\hline Interviewee 5 & Economist working on Agricultural productivity \\
\hline Interviewee 6 & Economist and director - Public sector agri-biotech lab \\
\hline Interviewee 7 & Economist specialized in Indian seed sector \\
\hline Interviewee 8 & Agricultural Economist \\
\hline Interviewee 9 & $\begin{array}{l}\text { Former Agricultural Scientist -Director of an NGO working on sustainable agricul- } \\
\text { ture }\end{array}$ \\
\hline Interviewee 10 & Researcher - Ethics in Science and Technology \\
\hline Interviewee 11 & Researcher - Plant biotechnology - Public sector agri-biotech lab \\
\hline Interviewee 12 & Researcher Technology Management - Public sector agri-biotech lab \\
\hline Interviewee 13 & Principal Scientist - Plant Pathology \\
\hline Interviewee 14 & Regional Manager - Marketing- with experience working for MNEs \& local firms \\
\hline Interviewee 15 & Research assistant - Plant Biotechnology- Public sector research lab \\
\hline Interviewee 16 & Scientist - Plant Biotechnology - Domestic seed firm \\
\hline Interviewee 17 & Scientist - Cotton breeding - Public sector research institution \\
\hline Interviewee 18 & Scientist- Plant Genetics - Public sector agri-biotech lab \\
\hline Interviewee 19 & Scientist- Plant Pathology (rice) - Public sector research institution \\
\hline Interviewee 20 & Experienced seeds and agrochemicals retailer \\
\hline Interviewee 21 & Senior seed breeder - specialist in cotton \\
\hline Interviewee 22 & Experienced seeds and agrochemicals distributor \\
\hline
\end{tabular}




\begin{tabular}{ll}
\hline No. & Role \\
\hline Interviewee 23 & Subject Matter Specialist (Agronomy / Seed Technology) - Public agri-biotech lab \\
Interviewee 24 & Subject Matter Specialist [Animal Husbandry] - Public sector agri-biotech lab \\
Interviewee 25 & Subject Matter Specialist [Entomology] - Public sector agri-biotech lab \\
Interviewee 26 & President, Farmers Association \\
Interviewee 27 & Assistant director, department of Agriculture (Administrator) \\
\hline
\end{tabular}




\section{Chapter 7. Localization of radical innovations, a multinational's perspective}

\subsection{Multinationals and localization of radical innovations in emerging coun- tries $^{22}$}

Localization of innovations refers to the successful market introduction of a new product or process after adapting it to fit well with the local conditions. Localization of innovations in emerging countries poses special challenges for foreign MNEs. On the one hand, emerging countries offer new and growing markets, cheap sources of qualified labour and sites for manufacturing where the regulatory costs are less. On the other hand, their very state of underdevelopment and lower per capita income poses constraints, especially if the products benefit not only the rich, but also the poor. This challenge is further increased if the product is a knowledge intensive, hi-tech, high-impact innovation that entails technological as well as social uncertainties. The problem may not lie with the targeted consumer alone, but with other stakeholders within and outside the market in the emerging country. In such cases, prior to and during the process of introducing the new product in the emerging country, the innovator MNE may have to establish business and social legitimacy, barring which its entire localization strategy may fail. Such a possibility is however at crosscurrents with the literature on localization strategies, which mostly assume that any new product and associated technology to be introduced in a targeted region has already, earned its legitimacy, if it serves unsatisfied needs or demand. Thus, the role of legitimacy in the localization strategies of MNEs launching hi-tech development-promoting innovations in emerging countries is an issue that merits a closer examination for a deeper understanding. This chapter therefore addresses the question, what are the best legitimization strategies for MNEs with respect to localizing their radical innovations in emerging countries?

Ensuring maximal access to high value innovations produced by MNEs is important for policy makers in emerging countries to promote inclusive development. By high value we mean that it is an essential commodity for livelihoods for promoting inclusive development in a developing country. For instance, clean water technologies and video games do not impact development to the same degree. In addition, if the innovation is also hi-tech, it is challenging for MNEs seeking to maximize innovation rent through introduction in new markets. On the one hand, they need to recuperate the high R\&D costs sunk into the creation of the hi-tech innovation, which drew upon the expertise of highly qualified and skilled person-

22 This chapter is based on the paper: Shyama Ramani, Ajay Thutupalli, Eduardo Urias. 2015. High tech, high value innovations in emerging markets: Legitimacy construction for localization. 
nel working with costly and sophisticated equipment. On the other hand, MNEs need to make the innovation accessible to the maximum extent possible, while also managing the IP vis-à-vis potential local competitors. To work towards such multiple objectives, MNEs will most likely have to formulate localization strategies that look beyond adaptation to language, culture and consumer preferences.

Localization strategies are distinct from globalization ones as standardization is not possible in all innovations given the enormous heterogeneity of countries in terms of their local conditions. In other words, localization strategies have to be context based. Legitimacy is perceived as an essential asset promoting a firms' stability enabling continuation of operations for long periods (Deegan, 2002). Therefore, in line with the view that organisations are part of a broader social system, legitimacy implies innovation acceptance not only from the targeted consumer, but also other societal stakeholders concerned with the safety and equity of its consumption in an emerging country.

Thus, in order to throw light on the question of legitimacy construction during the localization of an innovation the chapter develops a conceptual framework to identify the main dynamics of MNE legitimacy construction. It is then applied to develop detailed firm level case study of Monsanto and its Bt insect resistance technology. This is high technology innovation, implemented in an essential commodity which is seed with a high developmental impact. It is implicit that high quality seeds ensure better yields and livelihoods of farmers.

In Section 7.2 a conceptual framework to explain the localization process is formulated and applied to the seeds sector. Second, in Section 7.3 by applying the framework a detailed firm level case study of Monsanto and its localization of a radical innovation (Bt technology) in India is carried out. The results are discussed in Section 7.5. Section 7.6 concludes.

\subsection{Localization and legitimacy building: A conceptual framework}

Localization of innovations more often than not requires adaptations in terms of product, pricing, distribution, and communication (Schmid and Kotulla, 2011). Thus localisation efforts by an MNE can be seen as a three-component vector of strategies involving: (i) technology/product design and (ii) marketing, distribution and communication (iii) non-market investments. Technology design refers to adaptations in terms of re-design of the product or technology, so as to be functional vis-à-vis the demand and consumer preferences in the target country, while making use of local sources for manufacturing or distribution. Revisions in pricing, distribution, and communication strategies necessary to make the product affordable, complying with local regulation, norms and customs and accessing complementary assets form the marketing strategy. In addition MNEs might be engaged in 
non-market interactions with local actors, which may or may not necessarily relate to their innovation. These interactions could include corporate social responsibility activities and other philanthropic endeavours to create reputational value.

Following the 'National System of Innovation' approach, the context in which an MNE works in an emerging country is seen as a system comprising a set of actors bound together via networks, markets, alliances, regulation etc. whose individual actions jointly determine the economic performance of each and the collective outcomes of the system. For instance, an innovator MNE starts with links with its government as well as the public labs, universities, firms and financiers of its mother country, which enable it to create a hi-tech high value innovation. Then, when the innovator MNE seeks to commercialize such an innovation in an emerging country, it is also forced to deal with the state, local firms, public laboratories, universities, financial institutions and civic associations.

\subsubsection{Legitimization as a starting point and an outcome of a localiza- tion strategy}

Freeman (1997) classified the main sources of uncertainty in innovation process, as technological, commercial and organizational. For a firm, technological uncertainty concerns the scientific, technical, and engineering hurdles to be tackled in order to create a targeted new process or product. The success of the firm then depends on its knowledge base and capabilities, the general state of scientific knowledge and the problem being targeted. Commercial uncertainty is about whether the new technology can compete successfully (or not) in the marketplace. This is determined by the nature of the innovation, the nature of the supply and demand sides of the market, market competition and consumer acceptance. The third dimension - organizational uncertainty refers to the degree to which an organization could appropriate full innovation rents from commercialization. At the start of any innovation project a firm formulates its endogenous beliefs about the likelihoods of technological, commercial and organizational success, and initiates an innovation project only if the expected payoff net of cost is positive.

To the above uncertainties, Hall and Martin (2005), Hall et al., (2011), Pillania(2011), and Hall, Bachor, and Matos (2005) point out that with respect to the commercialization of radical innovations in emerging countries, societal uncertainties play an important role. Societal uncertainty is exogenous in the sense that it is determined by the response of societal stakeholders outside of the firm, who decide or influence whether to accept or approve the innovation, based on their beliefs about the innovation's potential socio-economic and/or environmental impact. They may not even be part of the innovation supply or distribution chain. However, implications of these outside challenges have received least attention from scholars. Most scholars studying how firms can reduce the technological and 
commercial market uncertainties of innovations assume societal acceptance or the absence of societal uncertainty (Jalonen, 2011).

Therefore, challenges may be founded in endogenous uncertainty or exogenous uncertainty or both. Among the former, technological uncertainty may be generated by the need for multiple localized designs that require expertise or tacit knowledge that the MNE does not possess. Marketing uncertainty may present itself in the form of complex distribution channels that vary across geographical zones and consumer preferences. Organizational uncertainty or impediments to the product or business sustainability may show up if systemic policy and regulation pushes for access through affordable prices that the MNE must negotiate over.

In a system fraught with the above uncertainties, consider an MNE that aims to introduce a high tech, high value innovation (termed simply innovation) in an emerging country. Its innovation eco-system in the emerging country is as shown in Figure 7.1. The most important stakeholder for an MNE is the targeted consumer. In addition it must take into consideration the activities of other actors like local firms, which may be producing either substitutes or complements. Universities and public research institutions provide valuable sources of qualified personnel and technical and scientific knowledge. Civil society can make or break innovations if there is uncertainty on socio-economic or environmental fronts. The emerging country State defines rules and regulations that firms must abide by.

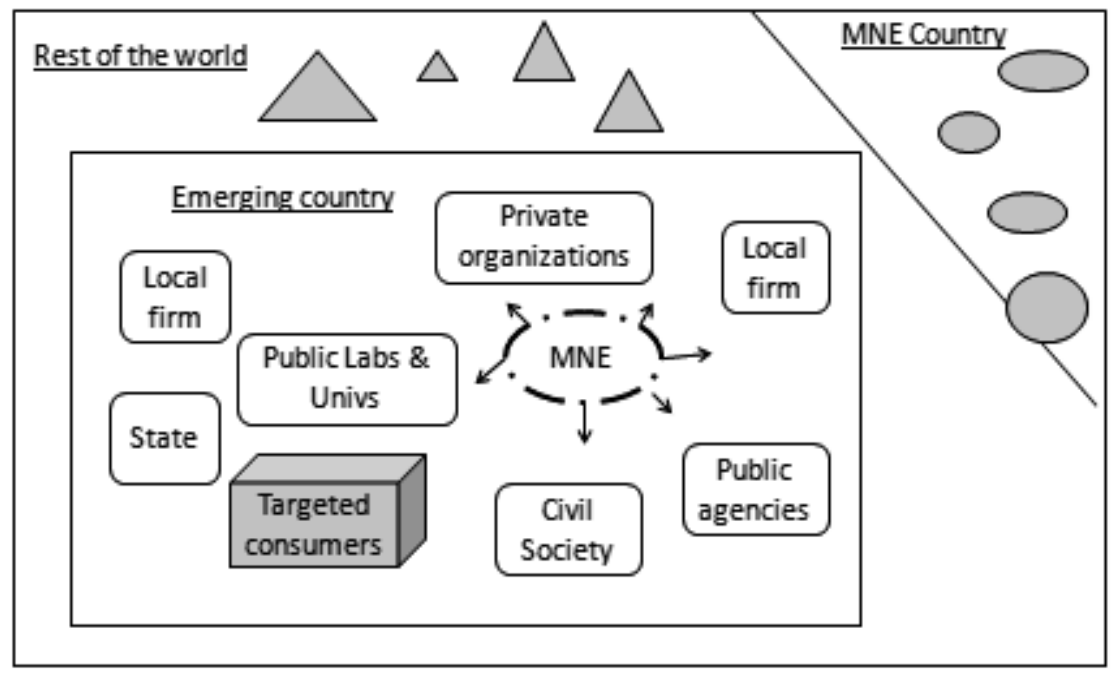

Figure 7.1 Innovation eco-system of an MNE with a high tech, high value innovation in an emerging country 
When the MNE enters the emerging country and introduces the innovation, if no other economic actor in the system contests its presence, then it can be considered to have business legitimacy. This intangible asset is necessary for firms to mobilize resources for production. At the same time business legitimacy it is an outcome of firm strategy (Dowling and Pfeffer, 1975; Zimmerman and Zeitz, 2002; Hall et al., 2014). But, neither does it exist always, nor can it be assumed to remain stable once acquired. Legitimacy fails to exist or is threatened whenever there is a lack of fit between the values associated with or implied by the MNEs' activities and those of the economic actors in its innovation system. These threats may take the form of legal, economic, and other social sanctions triggered by contestations from other economic actors (Dowling and Pfeffer, 1975). They may even involve actors who are not involved in the innovation value chain.

How can the legitimization efforts be integrated into the localization strategies of MNEs to counter such threats? Legitimization can be achieved through 'outreach' to other economic actors in the system to address their concerns. In other words, prior to entering an emerging country with an innovation, an MNE has to evaluate the possibility of challenges being issued by any of the actors in the eco-system and plan for addressing the same through an outreach strategy. An outreach strategy is necessarily based on the beliefs of the MNEs vis-à-vis the other actors in the system since the MNE will have only incomplete and imperfect information on the possible challengers and their rationale beforehand.

Moreover, four types of outreach interactions can be proposed to tackle challenges: co-existence, market transactions that include commercial and non-commercial agreements, compromise, and confrontation. Whenever an emerging country actor does not pose a challenge, there is simply co-existence and corresponding outreach effort of MNE is near zero. Market transactions can involve exchange of assets, technologies, products, materials and services at existing market prices. Agreements can vary from price negotiations to collaborations when two or more or organizations work together for mutual benefit. Compromise refers to actions that involve a real cost to the MNE with a positive gain for the other party in the ecosystem - at least in the short run. Confrontation refers to disputes that are taken to third party, say a court, for settlement. Each of these outreach actions are embedded in one or more of the components of the localization strategy, i.e. technology design, marketing or non-market activity.

In this manner, legitimization is a starting point and an outcome of a localization strategy and crucially influences the returns to introduction of the innovation. We now turn to the issue of localization for radical innovations in agriculture and then evaluate the specific case of Monsanto in India. 


\subsection{Localization of radical innovations in the agri-biotech sector}

The localization process of the new transgenic technologies in emerging countries by multinationals, especially Monsanto has been marked by controversies (Hall et al., 2014). In their localization strategies of genetically engineered crops, agribiotech MNEs have been most challenged by civil society, farmers groups and in certain cases the State itself. The problem has arisen as MNEs have over focused on reducing their techno-commercial uncertainty to recuperate their $R \& D$ costs and seek rents on investment without investing in efforts to establish other forms of legitimacy. The societal confrontation has two components: economic and ecological.

On the economic front, first, there is an ideological clash between the societal stakeholders worldwide, especially in emerging countries, who are concerned about the loss of sovereignty in seeds because they are essential commodities and the MNEs. This triggers local actors such as NGOs as well as political actors to question the legitimacy of the technology and the Multinational in the economy as evidenced by the case of GM cotton in India and GM cotton and soybean in Argentina and Brazil (Newell, 2007; Hall et al., 2011; Newell, 2009; Arza and van Zwanenberg, 2014; Hall et al., 2008). Indeed the prospect of the propriety rights of good quality seeds moving entirely into private hands that have built tight appropriability regime via patents of life forms and plant breeder's rights, and their strict enforcement via TRIPS 23 is a source of anxiety for many policy and civil society representatives in the emerging countries (Shiva, 2004; Kloppenburg, 2014).

Second, the targeted buyers, namely plant breeders and farmers complain of problems of access due to the non-affordability of the innovation. High royalties or technology fees increase the socio-economic uncertainty for local firms and small farmers raising questions on the legitimacy of the technology its MNE in the host country. There are many cases in which the pricing and higher technology fee has become an impediment for the legitimization of the technology (Sadashivappa and Qaim, 2009; Arora and Bansal, 2011). Moreover the pricing behaviour of the large seed and agrochemicals firms is often found to be strategic and discriminating in the form of differential pricing or Technology Use Agreements (Fulton and Giannakas, 2001)

On the ecological front, the uncertainties linked to the environmental and health outcomes have become a major bottleneck for legitimization of GM crops. It is difficult to ascertain the medium to long term risks (or even benefits) of the new seed

${ }^{23}$ TRIPS is the most comprehensive multilateral agreement on intellectual property to date and are administered by the World Trade Organization (WTO). TRIPS was signed in 1994 and sets down minimum standards for intellectual property regulation as applied to nationals of other WTO Members. 
technology from the laboratory or field trial data because of the genuine scientific uncertainty that emerging technologies come with. The technology has to withstand the test of time and there are on-going debates as to how many years is exactly long term. Outreach with regulatory authorities, government departments dealing with the environmental and bio safety, farmer groups and NGOs is therefore inevitable in the process of localization of GM varieties.

This brief excursion into the evolution of legitimacy problems of modern seed sector yields the following table of localization strategies for agri-biotech MNEs.

Table 7.1 Localization and Legitimization Strategy matrix for MNEs in agri-biotech sector

\begin{tabular}{|c|c|c|c|}
\hline $\begin{array}{l}\text { Localization strategy } \rightarrow \\
\text { Legitimization outreach } \sqrt{\Omega}\end{array}$ & $\begin{array}{l}\text { Technology/Product } \\
\text { design and development }\end{array}$ & $\begin{array}{l}\text { Market distribution } \\
\text { (pricing, marketing and } \\
\text { distribution) }\end{array}$ & $\begin{array}{l}\text { Non-market distri- } \\
\text { bution }\end{array}$ \\
\hline Collaboration & $\begin{array}{l}\text { Joint Ventures, R\&D col- } \\
\text { laborations with local } \\
\text { actors. }\end{array}$ & $\begin{array}{l}\text { With local actors for } \\
\text { marketing and distribu- } \\
\text { tion. }\end{array}$ & $\begin{array}{l}\text { Sustainable agricul- } \\
\text { ture projects in } \\
\text { collaboration with } \\
\text { farmers, and public } \\
\text { sector institutions. }\end{array}$ \\
\hline Confrontation & $\begin{array}{l}\text { With farmer groups, civil } \\
\text { society groups, state on } \\
\text { outcomes of the technolo- } \\
\text { gy. }\end{array}$ & $\begin{array}{l}\text { With farmer groups, civil } \\
\text { society groups and state } \\
\text { on access, uncertainties } \\
\text { in outcomes. }\end{array}$ & \\
\hline Compromise & & $\begin{array}{l}\text { With respect to Pricing } \\
\text { or Technology fees. }\end{array}$ & \\
\hline $\begin{array}{l}\text { Co-existence } \\
\text { (Passive) }\end{array}$ & & & $\begin{array}{l}\text { With NGOs, Farmer } \\
\text { group and consum- } \\
\text { er organizations. }\end{array}$ \\
\hline $\begin{array}{l}\text { Market Transactions other } \\
\text { than collaborations (Com- } \\
\text { merce) }\end{array}$ & $\begin{array}{l}\text { Licensing of technology to } \\
\text { local firms, Mergers and } \\
\text { acquisitions, Sales and } \\
\text { marketing agreements. }\end{array}$ & $\begin{array}{l}\text { With local firms in Sales } \\
\text { and Marketing. }\end{array}$ & \\
\hline
\end{tabular}

\subsection{Monsanto and its localization challenges in India}

By 1996, Monsanto commercialized Bt-cotton varieties in the US with great success. At this point, it turned to emerging countries to expand its market. India was a natural lucrative target for Monsanto, because despite having the largest cotton growing area in the world (about 12 million hectares in 2013), during the 1990s Indian cotton yields were amongst the lowest in world with severe pest problems requiring high pesticide usage (cotton accounted for 54\% of the total pesticide consumption in India by 2000) (Raghuram, 2002). Therefore, small farmers were in distress with debt and environmental damage. 
Monsanto approached the Indian government to get approval to commercialize the technology in India. But this was refused on the grounds that the technology fees Monsanto planned to charge were too high (Newell, 2007). To counter this challenge, Monsanto began to seek alliances from Indian firms. The partner chosen was Mahyco (Maharashtra Hybrid Seeds Corporation), which was the leader in the Indian conventional cotton hybrids market. Mahyco got approval from the DBT (Department of Biotechnology) to import Bt-cotton seeds developed by Monsanto to backcross into Indian cotton varieties in March 1995. To strengthen this alliance further, in 1998, Monsanto obtained a 26\% stake in Mahyco and created a 50: 50 joint venture, called MMB (Mahyco Monsanto Biotech) for the diffusion of Bt technology in India.

A second challenge came in April 1998, after the Department of Biotechnology approved small scale field trials of Bt-cotton by Mahyco. However, Mahyco carried out the field trials on a much larger scale than agreed upon and this deviation caught the attention of anti-GMO activists and farmer groups. In November 1998, KRRS (Karnataka Rajya Raitha Sangha) a farmers' association from the state of Karnataka destroyed the cotton fields in which the field trials were being carried out. In January, 1999, a case challenging the legality of even the field trials authorized by the DBT was filed by well-known activist Vandana Shiva in the Supreme Court.

This challenge was partially mitigated by the regulatory authorities themselves, because while the case was still pending with the Supreme Court in July 2000, the Genetic Engineering Approval Committee (GEAC) gave a green signal to Mahyco to carry out large-scale field trials in several states and to produce Bt-cotton seeds. However a year later in June 2001, under pressure from activists' and NGOs' protests the GEAC insisted that field trials of Bt-cotton be extended by another year and that large-scale field trials on 100 hectares be carried out with close monitoring by the ICAR (Indian Council of Agricultural Research).

Then, while Mahyco and Monsanto waited patiently, carrying out additional field trials in several states to decrease the environmental and health related uncertainties, a very strange thing happened. In October 2001, farmers in Gujarat noticed that at least $30 \%$ of the cotton fields seemed to be unaffected by the severe bollworm infestation that was causing havoc in the state. Following this MMB filed a complaint to GEAC against a local seed firm Navbharat, for diffusing the illegal Btcotton seeds, when approval for commercialization was still pending. Navbharat, a local seed company founded by a US trained former employee of Mahyco (Kulkarni, 2003) defended itself claiming that the hybrids were developed from insect resistant plants identified by natural selection followed by a series of backcrossings. However, in later legal hearings it was confirmed that Navbharat 151 
was indeed genetically modified and was sold in other states as well though it was not the same as the MMB Bt-cotton, as a different parental line with the same Cry1A(c) gene had been used to produce this hybrid (Venkateswarlu, 2001).

The commercialization of illegal Bt insect resistant varieties (illegal because not approved by the Ministry of Environment and Forests, MoEF) in different Indian states by Navbharat in turn helped Monsanto gain publicity for its new Bt insect resistance technology, as farmers were extremely satisfied with its performance. Indeed, the challenge was now turned against the regulatory authorities by the protesting farmers. Thus, within six months, in March 2002, the GEAC approved the commercialization of three varieties of insect-resistant Bt-cotton hybrids (Mech-12 Bt, Mech-162 Bt and Mech-184 Bt) for the central and southern states. Since then the diffusion of Bt-cotton in India has been phenomenal.

After the success of MMB Bt-cotton became evident, another type of challenge emerged in 2006. While adoption of Bt-cotton clearly increased profits, the increase in the cost of cultivation due to the higher seed price (Sahai and Rahman, 2003; Sahai and Rehman, 2004) made NGOs and farmer organizations voice their concern. Eventually, the government of Andhra Pradesh brought the issue to the deliberation of the Monopolies and Restrictive Trade Practices Commission (MRTPC) (Sadashivappa and Qaim, 2009). It was identified that the higher seed price was due to the higher technology fees paid by the local firms towards the Bt trait to MMB. Almost 78\% of the cost of a packet of cotton seed was being charged by MMB as the trait value (Arora and Bansal, 2011). The commission therefore questioned MMB the reason for such high fees for the trait, to which MMB responded that the returns were being used to develop other products helpful for farmers. The commission then asked MMB to reduce the trait value to a reasonable level for which MMB offered to reduce it to INR 900. However the Andhra Pradesh government insisted to reduce it further to which MMB refused. The issue did not move towards any resolution thereby prompting the central government's intervention. The central ministry for agriculture backed the commission's recommendation and therefore MMB took the issue to the Supreme Court. Again, the Supreme Court upheld the directive of MRTPC. Meanwhile the State government of Andhra Pradesh set a price ceiling of INR 750 for a packet of 500 grams of Btcotton seeds while other states followed suit.

During the years thereafter a variety of other legitimacy challenges were also hurled at Monsanto. There were regular reports in the media about NGOs, farmer groups, scientists and corporate representatives arguing for and against Bt-cotton in terms of impact on farmer profits, farmer indebtedness, farmer suicides and damage to health of farmers, cattle and the environment. Socio-economic studies finding positive as well as negative outcomes of Bt-cotton appeared in academic 
journals as well as in NGO reports (Chapter 3). Due to this controversy, a moratorium on the introduction of any other transgenic plant varieties and their field trials in India was initiated in 2010.

Finally, the resounding success of Bt-cotton with farmers combined with the strategic patience of Monsanto seems to have paved the way for the lifting of this ban. In July 2014, GEAC cleared the approval of field trials of a range of food crops including rice, mustard, cotton, chickpea and brinjal which shows that the legitimization efforts of Monsanto have paved the way for other MNEs as well as Indian firms to exploit the lucrative Indian GM hybrids market.

Further, the interactions between Monsanto and other actors in the Bt-cotton innovation system are elucidated in Fig. 7.2.

MoST-DBT: Ministry of Science and Technology- Department of Biotechnology; MoEF: Ministry of Environment and Forests; MNE: Multinational Enterprise; NGOs and CS: Non-governmental organizations and civil society; MMB: Mahyco Monsanto Biotech (India) Limited; MHPL: Monsanto Holdings Private Limited.

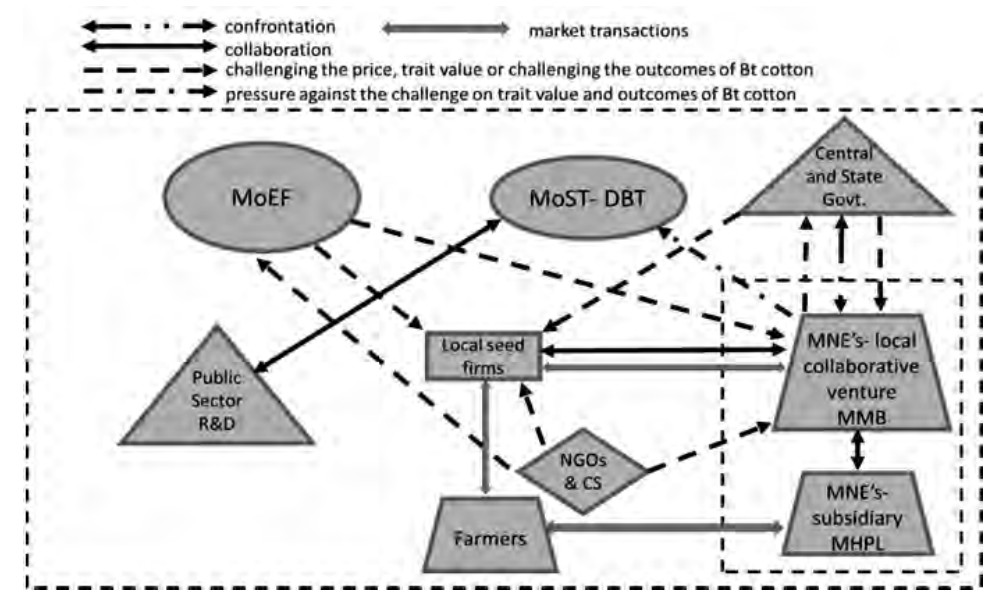

Figure 7.2 Types of interactions between Monsanto and the actors within its innovation ecosystem in India

The summary of all the challenges Monsanto faced with each of the key stakeholders in the Indian innovation system and its strategic options for legitimization in each case are elucidated in Table 7.2. Also presented in the table are Monsanto's chosen actions and their outcomes. 
Table 7.2 Monsanto's outreach strategy with respect to Bt cotton in India

\begin{tabular}{|c|c|c|c|c|c|c|}
\hline $\begin{array}{l}\text { Actors in } \\
\text { the } \\
\text { innova- } \\
\text { tion } \\
\text { system }\end{array}$ & $\begin{array}{l}\text { Bargain- } \\
\text { ing pow- } \\
\text { er Mon- } \\
\text { santo vs. } \\
\text { local } \\
\text { actor }\end{array}$ & $\begin{array}{l}\text { Challenges of } \\
\text { localization for } \\
\text { Monsanto }\end{array}$ & $\begin{array}{l}\text { Level of } \\
\text { Exoge- } \\
\text { nous } \\
\text { uncer- } \\
\text { tainty }\end{array}$ & $\begin{array}{l}\text { Available strate- } \\
\text { gies for establish- } \\
\text { ing legitimacy by } \\
\text { Monsanto }\end{array}$ & $\begin{array}{l}\text { What Monsanto } \\
\text { did? }\end{array}$ & Outcome \\
\hline $\begin{array}{l}\text { State } \\
\text { (MoE, } \\
\text { GEAC, } \\
\text { state } \\
\text { govern- } \\
\text { ments) }\end{array}$ & $\begin{array}{l}\text { High vs. } \\
\text { low }\end{array}$ & $\begin{array}{l}\text { Adhering to the } \\
\text { statutory process- } \\
\text { es for regulatory } \\
\text { approval and } \\
\text { commercialization } \\
\text { (regulatory policy, } \\
\text { environmental } \\
\text { policy), demon- } \\
\text { stration of superi- } \\
\text { or technology } \\
\text { performance, }\end{array}$ & High & $\begin{array}{l}\text { Compromise with } \\
\text { the states on } \\
\text { pricing and regu- } \\
\text { lation } \\
\text { Confront with the } \\
\text { states on pricing } \\
\text { and regulation }\end{array}$ & $\begin{array}{l}\text { Published the field } \\
\text { trial data - Adhering } \\
\text { to GEAC, MOE rules. } \\
\text { Compromised and } \\
\text { conducted field } \\
\text { trials multiple times } \\
\text { for second round of } \\
\text { approval. } \\
\text { First confronted } \\
\text { then compromised } \\
\text { on technology fees / } \\
\text { trait value with } \\
\text { state governments. }\end{array}$ & $\begin{array}{l}\text { Regulatory } \\
\text { approval and } \\
\text { commerciali- } \\
\text { zation,Lower } \\
\text { cost of cultiva- } \\
\text { tion for farm- } \\
\text { ers that } \\
\text { helped build } \\
\text { the socio- } \\
\text { political } \\
\text { legitimacy. }\end{array}$ \\
\hline $\begin{array}{l}\text { Local } \\
\text { firms }\end{array}$ & $\begin{array}{l}\text { Low vs. } \\
\text { Low }\end{array}$ & $\begin{array}{l}\text { Adaptation and } \\
\text { technology } \\
\text { demonstration, } \\
\text { Dealing with IPR } \\
\text { leakage issues, } \\
\text { local competition } \\
\text { in technology } \\
\text { market, filling } \\
\text { MNEs knowledge } \\
\text { gap in local mar- } \\
\text { kets }\end{array}$ & High & $\begin{array}{l}\text { Collaborate } \\
\text { (joint-ventures, } \\
\text { R\&D collabora- } \\
\text { tion) } \\
\text { Market transac- } \\
\text { tions (Vertical } \\
\text { integration via } \\
\text { mergers and } \\
\text { acquisitions, } \\
\text { licensing) }\end{array}$ & $\begin{array}{l}\text { Collaboration - } \\
\text { Setting up joint } \\
\text { venture MMB for } \\
\text { sub-licensing } \\
\text { Collaboration- with } \\
\text { Mahyco for initial } \\
\text { Bollgard hybrids } \\
\text { Market transactions } \\
\text { - Sub-licensing its } \\
\text { genes to local firms } \\
\text { via MMB }\end{array}$ & $\begin{array}{l}\text { Market lead- } \\
\text { ership in } \\
\text { Technology } \\
\text { via demon- } \\
\text { strated agro- } \\
\text { nomic per- } \\
\text { formance of Bt } \\
\text { technology. }\end{array}$ \\
\hline NGOs & $\begin{array}{l}\text { Low vs. } \\
\text { High }\end{array}$ & $\begin{array}{l}\text { Convince on socio- } \\
\text { economic and } \\
\text { environmental } \\
\text { risks via evidence } \\
\text { that the product is } \\
\text { economically and } \\
\text { ecologically non- } \\
\text { harming }\end{array}$ & High & $\begin{array}{l}\text { Compromise } \\
\text { On access, envi- } \\
\text { ronmental and } \\
\text { health uncertain- } \\
\text { ties } \\
\text { Confront } \\
\text { On access, envi- } \\
\text { ronmental and } \\
\text { health uncertain- } \\
\text { ties }\end{array}$ & $\begin{array}{l}\text { Passive co-existence } \\
\text { participated in } \\
\text { public debates } \\
\text { arranged by MoE, } \\
\text { awareness cam- } \\
\text { paigns for consum- } \\
\text { ers and distributors. }\end{array}$ & $\begin{array}{l}\text { Declined } \\
\text { resistance } \\
\text { from NGOs } \\
\text { with respect } \\
\text { to Bt cotton } \\
\text { over the years }\end{array}$ \\
\hline Farmers & $\begin{array}{l}\text { High vs. } \\
\text { Low }\end{array}$ & $\begin{array}{l}\text { Convince on value } \\
\text { added, ensuring } \\
\text { repeated adoption } \\
\text { /reuse }\end{array}$ & High & $\begin{array}{l}\text { Compromise on } \\
\text { technology fees. } \\
\text { Confront on } \\
\text { technology fees. }\end{array}$ & $\begin{array}{l}\text { Market Transac- } \\
\text { tions } \\
\text { Compromised on } \\
\text { trait value }\end{array}$ & $\begin{array}{l}\text { Commercial } \\
\text { success of Bt } \\
\text { cotton }\end{array}$ \\
\hline
\end{tabular}




\subsection{Discussion}

The analysis of Monsanto and its Bt technology in India clearly validates our systemic approach and conceptualization of legitimacy. Monsanto faced direct confrontations in India with public agencies (MoE, GEAC, and state governments) and NGOs linked to concerns about the long term impact of the innovation on human health and the ecology. To this, was added the technological uncertainty and marketing uncertainty given the radical nature of the innovation which nevertheless required localization in terms of technology design and marketing. Monsanto seems to have handled these challenges successfully through a mix of passive coexistence and compromise with public agencies and NGOs and fruitful collaborations and market agreements with local firms.

With respect to challenges issuing from the emerging country eco-system, they were mainly from public agencies or groups representing civil society. Neither local firms nor public laboratories ${ }^{24}$ triggered confrontations with the MNEs. The exogenous uncertainty associated with the MNE innovation in emerging countries was founded on either contrary visions of socio-economic and environmental impact of the innovation or the need to ensure maximal access to the innovation as it was crucial for livelihoods. As legitimization efforts lowered exogenous uncertainty, the role of commercial transactions and agreements increased, while that of negotiated agreements and confrontations decreased.

The case study also refines the conceptual insights through the following results.

Collaboration with local firms can be pursued if they share the costs of legitimization construction to reduce technological and marketing uncertainties. At the outset, the degree of technological uncertainty and marketing uncertainty associated with the innovation determines the need for collaboration. For instance, if the innovation is a novel input that must be integrated into a final product, for which the market is dominated by local firms, then it makes sense to collaborate. Moreover, if the innovation is very novel, then collaboration with local firms helps to share the

\footnotetext{
${ }^{24}$ In 2009, the approval of a public sector indigenously developed BNLA106 event and its variety BNBt (developed by University of Agricultural Sciences, Dharwad in collaboration with National Research Centre on Plant Biotechnology, New Delhi, Central Institute for Cotton Research, Nagpur) faced a controversy. Arguments were made that BNLA106 had traces of Monsanto's gene MON531. A three member ICAR committee looked into the matter and found sever lapses in the implementation of the project and suggested that the event has to again go through a full cycle regulatory approval K.Venkateshwarlu (2012). The analysis in this chapter did not include this episode as there is no direct role of Monsanto. In fact in 2012, Monsanto's spokeswoman Michelle D’Souza when asked to comment said "It is an internal matter of ICAR”Jayaraman (2012)
} 
technological risk of redesigning the product to fit local demand. Collaboration is also useful if the marketing platform is complex and heavily localized as in India. Gene constructs or gene events are like intermediate inputs that must be incorporated into agronomically superior variety that is robust for a particular agroecology. Clearly if the targeted country exhibits high heterogeneity in terms of agro-ecological zones, it is more profitable to share the cost of 'adapting technology design' with local firms. The tacitness of the in-situ knowledge base i.e. the know-how on local agro-ecology makes it all the more costly and time consuming for a MNE to set up its own subsidiary and carry out the adaptation process. This is indeed the case of seeds, which requires well established channels of seed dealers, distributors and retailers carrying out their work in local dialects and often with social ties to local farmers. Thus, Monsanto could not localize its Bt technology without collaboration with local firms.

The need for collaboration introduces additional questions of partner selection among local firms and contract design for collaboration. According to the analysis partner selection among local firms is determined by potential to contribute to MNE returns to innovation introduction through reducing any kind of risk generated by the endogenous and exogenous uncertainties. This was exactly the case with Monsanto which chose Mahyco, with the largest distribution network of cotton seeds in India and a success story in Indian cotton hybrids. Monsanto also benefited from the brand Mahyco, under whose name the first hybrids were sold. Mahyco's sales and marketing network was especially critical for the success of the technology in the initial years. Later on local firms also partnered with Monsanto (MMB) through licensing agreements.

No general legitimization guidelines can be formulated to maximize MNE returns under a confrontation, except that an MNE must re-evaluate its bargaining power at the beginning. Confrontation is essentially a bargaining game, but bargaining power is determined by the contextual specificities of the time and it is usually conducted under incomplete information, with the local challenger and the MNE not being fully aware of the bargaining power of the other. Monsanto's confrontation with the Andhra Pradesh state government in technology fees did not yield any advantage.

Compromise is the most probable but not the only outreach strategy possible after a confrontation. Astute practice of strategic patience may be necessary. For instance, when Monsanto was confronted in the Supreme court for its high technology fees (i.e. royalties) for GM traits, it made sense to compromise by the way of reducing its innovation rent which brought down the price of a packet of cotton seed (500gm) from INR 1600 to INR 750. This was an expected outcome as the bargaining power of Monsanto vis-à-vis the Supreme Court of India is negligible. 
However, with the NGOs, civil society and farmer groups, Monsanto chose not to confront directly and instead played the strategy of passive co-existence. This was possible because the societal challengers were against GM technology in general, rather than Monsanto in particular. This was also fortuitous for Monsanto, as it could then deal with this challenge through acquiescing to the requests of Ministry of Environment for more trials etc. as its bargaining power vis-à-vis these protestors was unclear.

This leads to the final result.

All aspects of an outreach strategy are important: what kind, towards which local actor and at what time. When challenges are issued by the state, regulatory agencies and civil society groups, legitimization efforts by the way of passive co-existence (strategic patience), collaboration or compromise should be explored before confrontation is launched. Monsanto was forced to compromise on technology fees in order to attain legitimacy, wherein an initial compromise may have paid more.

The case also highlighted avenues for further research, as it showed that the spectrum of outreach initiatives could be greater than that proposed in the conceptual model. The analysis in the chapter is limited to formal interactions, while it is well known that many informal activities are also part of the game. Though outside the scope of this study, it is also necessary for scholars to identify and understand the systemic loopholes that can let unethical actions, threats and lobbying that detract innovations from markets.

\subsection{Conclusion}

How can MNEs prepare to satisfy the diverse values and aspirations of different stakeholders in an emerging country when commercializing its high tech high development potential innovations? By way of an answer, the present chapter explored the premise that to ensure maximal returns from launching hi-tech high impact innovations in emerging countries, the localization vector that includes the technology, market distribution and non-market plans of MNEs have to be preceded and sustained through efforts that address innovation legitimacy. Legitimacy is embedded in the localization process via strategic interactions or outreach with the actors in the emerging country innovation system. The outreach space includes passive co-existence, market transactions, market and non-market agreements, confrontation and compromise. A conceptual model was developed and validated by analyzing the localization of Bt technology by Monsanto in India.

The case offered insights on the localization efforts those that worked and those that did not in diverse sectoral and innovation system contexts. The analysis reaffirmed that it pays for an MNE to invest in legitimacy construction through outreach. 


\section{Chapter 8. Concluding Remarks}

\subsection{Main results}

While radical technological breakthroughs lay the foundation for a major shift in an existing technology domain, they entail a range of socio-economic and environmental uncertainties. These uncertainties are likely to create a range of policy problems in order to ensure sustainability. At the same time, they can bring about significant changes in the innovation system generating new strategic problems or opportunities for other actors such as farmers, local firms and public laboratories. Combining these two aspects and in order to contribute to rational policy design vis-à-vis GM crops and other new technologies to come in agriculture, the thesis set out to answer the overarching question: What are the drivers of sustainability and catch-up in the context of technology paradigm shifts in agriculture?

Productivity increase in agriculture can be channeled via technological improvements that save labour or push up the yields. With regard to yields, recent major technological transitions include the GR Modern Varieties and GM crops. While the transition to GR is seen as causing resource degradation in many countries, the diffusion of GM plant varieties raised questions on the long term economic and environmental impact of this paradigm. Therefore the thesis examined the issues underlying the dynamics of technological transitions using the empirical setting of GR and GM transitions.

In Chapter 2 the theoretical elements underlying a technology paradigm shift were traced within the innovation literature. The theoretical elements were refined and combined to represent the process of technology transition in agricultural production. The final theoretical construct integrated both the evolutionary responses of ecology that strive to achieve biological or physical efficiency along with the evolutionary behaviour of economic actors trying to achieve economic efficiency. The theoretical elements that constitute a technology paradigm shift are illustrated using agricultural technologies in general and empirical evidence from GR and GM cotton transitions in India.

Using the literature on GR and GM cotton transitions in India, chapter 3 illustrated that economic and ecological outcomes that typify a technology paradigm can be diverse. While the GR transition is marked by questions on environmental outcomes, Bt cotton in India raised questions on both socio-economic and ecological outcomes. Although on socio-economic front the Bt cotton analysis does not reveal any uncertainity, on ecological front the uncertainty became evident in terms of evolutionary changes to cotton pests. 
At a systemic level, chapter 4 examined how controversies emerge during technological transitions in agriculture from the evidence provided by the transitions to GR and GM cotton in India. It demonstrated that technological transitions cannot be associated with any notion of consistent 'equilibrium' for they are the outcome of strategies of actors who rather than optimizing, continuously adapt to a shifting environment. Consequently with such continuous co-evolution of economic actors and ecology, the system cannot be associated to a static equilibrium. It is possible that the outcomes are neither socially optimal nor economically or ecologically efficient requiring the intervention of a social planner. Thus, technology paradigm shifts may create winners and losers and subsequently social dilemmas such as public controversies that require attention from policy makers.

The analysis suggested that trigger points of controversies can emerge at any stage of a technology transition. In particular, with respect to agricultural technologies, the ecological outcomes rather than economic outcomes are likely to be stronger focal points of controversy. It is shown that high immediate payoffs can override concerns founded on scientific uncertainty in the adoption of new technologies. Finally controversies are also likely to increase as the innovation system becomes complex.

In chapter 5, in order to examine how sustainability concerns are integrated in drivers of new technology adoption by heterogeneous farmers, a typology of technology adopters- some myopic and some with foresight on the ecological concerns -was integrated into the model of new technology adoption and tested using survey data. The analysis revealed a close association between resource endowments and farmer preferences towards technology choice and its implementation. While impact perceptions of Bt cotton adopters were heterogeneous, remarkably, small farmers with rain fed land were ecologically conscious than their counterparts with large irrigated farms. As a consequence they were more compliant to sustainable farm management practices such as refuge compliance. Imitative farmers preferred to mimic the successful farmers of the locality than to spend time learning about sustainable practices.

However even the ecologically concerned farmers do not seem to be fully or well informed on the scientific rationale and consequences of their practices such as refuge compliance. For instance, the consequences of non-compliance to refuge and its translation into higher ecological and economic risk in the future do not seem to be completely understood by the farmers. Even if a majority of the farmers are myopically profit driven, a constant awareness creation might lead them to adopt a longer term perspective. This is of course a very big challenge, because it is extremely difficult to gather farmer groups, and educate them as they are already practitioners with a conventional knowledge base and belief systems. This is even 
more so for large farmers with irrigation who are less concerned about the ecological consequences.

Chapter 6 provided conceptual and empirical insights on the strategies of local firms in emerging countries vis-a-vis new agricultural technologies. The analysis started with the premise that while agricultural production, which relies heavily on agro-ecological conditions remains largely unchanged, the rise of biotechnology, has altered the conventional scientific approach for finding solutions for better yields. The modern day agricultural innovation - strongly punctuated by agribiotech R\&D is configured in a distinctive way. Each firm can chose from diverse strategies, considering its strength in the knowledge base constituted by global and in-situ components, to identify its preferred areas of investment. The underlying technology and the differences in capabilities presented diverse pathways of catch-up for local firms in the follower countries.

Chapter 7 offered insights on the strategy of multinational firms in promoting their radical innovation with high developmental impact in emerging countries. It highlights the localization efforts that worked and those that did not for Monsanto in India.

\subsection{Policy recommendations}

In the light of the above results, the following policy recommendations can be made to promote sustainability and technological catch-up in the context of technology paradigm shifts in agriculture.

First, there is real scientific uncertainty about the long term ecological outcomes of radical innovations such as GM crops and such uncertainty can be exploited by economic actors with vested interests to strengthen their stance on complex sciences and thereby posing a major hindrance to the building up of consensus between scientists, farmers, civil society, and policy makers in the innovation system. To lower controversy there is a need for investments in long term evaluation and agencies to monitor the environmental and biosafety aspects with representatives from principal stakeholder groups - environmental scientists, agricultural scientists, economists, lawyers and civil society groups. This may not only decrease the uncertainty but also minimize the ex-post allocation of valuable resources for public consensus building if technological alternatives are missing. Also possible misallocation of resources can be minimized by having a regulation that clearly defines the financial responsibilities of the State, the seed firms and the farmers in the case of adverse events.

Second, programmes for catch-up of public sector research need to be strengthened through support and reform. Buttel, Kennel and Kloppenberg (1985), as early 
as 1985, before the commercialization of any GM varieties anywhere in the world, called for a greater public investment in agricultural research to avoid the shift of power over technology options to the private sector.

Third, R\&D support for the creation of new conventional varieties and non-GM alternatives must be increased to ensure maximum flexibility of technology choices. In other words, not only should resources be allocated to catching up in transgenic crops but efforts must also be made to develop better non-transgenic varieties. However, any alternative that aims to compete with varieties such as Bt cotton must be as efficient in terms of productivity and generation of revenue. It has been pointed out that if any Pareto-superior technology in the innovation system exists in a dormant state, making the switch to it will be less costly for a social planner than to kick start altogether new technology searches (Kemp and Soete, 1992).

Fourth, agricultural extension system will do well by accompanying farmers in educating about sustainable practices with regard to implementation of new technologies. Such an accompaniment can take two forms: first, knowledge sharing, testing and monitoring of agro-ecological variables, and second, protection against risk. Farmers are practitioners and they are constantly learning, thus, the extension can also be educated by them. In other words, teaching and learning should not be top-down but interactive where good practices can be shared. Then, there is soil testing for optimal dosage of fertilizers which is yet to be taken up widely by farmers in India. The ongoing efforts in this direction can be expanded further. Finally, assuming that large numbers of imitating farmers are motivated by risk reduction, firms and state agencies can do well to accompany them through crop-insurance.

Fifth, for regulatory policy in India (and other similar country contexts), the monitoring and outreach programmes for regulation must be revamped to ensure greater regulatory compliance towards sustainable farm management practices. Public sector extension services must educate farmers more efficiently in practices like refuge compliance and create awareness about practices such as resistance management in the case of insect resistant GM crops. It might be worthwhile to revisit the compliance monitoring mechanism for decreasing possible externalities, especially as GM varieties are being set for larger release. After being very vocal and continually investing to build up a comprehensive regulatory architecture and bureaucracy, India opted to make refuge compliance voluntary rather than mandatory. Making refugia voluntary was a policy design imitative of the US where it was then the case. What is noteworthy is that, the US which started with voluntary guidelines has reverted to some degree of control. After some years of voluntary refuge, starting 2000, the US Environmental Protection Agency has put in place mandatory 
refuge requirements for all Bt field corn hybrids in some states (Murphy et al., 2006) ${ }^{25}$. Moreover the information on the need and standard requirements of compliance and even calculations and structure of refuge for farms are readily available online in the US (irmcalculator.com). But, in India this is not the case.

Turning now to firm strategy, the thesis strongly suggests that further radical innovations whose impact on the environment, ecology and human health is not completely known can polarize the systemic stakeholders into different proinnovation or anti-innovation clusters depending on the actor's knowledge base, risk preferences and own objectives. Here investment in reducing the scientific uncertainty and engaging in dialogue with challengers to reduce the informational asymmetry will be most useful. Further, high value innovations that impact the livelihoods of a large population, which in turn boost sectoral performance will be monitored by public agencies. Here direct bargaining can be triggered between MNE and public agencies over maximizing access to local users vs. maximizing innovation rent for the MNE. This is a classic zero-sum game, where gains for one party necessarily implies losses for the other. To tackle confrontations MNEs must transform the classic zero-sum game with the challenger into a positive sum game involving many actors other than the challenger. Thereby it strengthens its bargaining power.

While the transition to agri-biotech provided a window of opportunity to catch-up, firms' cumulative learning and access to foreign know-how play a major role in the catch-up. Identifying the right strategy to combine external and internal knowledge to develop Bt cotton hybrids was found to be key differentiator for market success of local firms vis-à-vis MNEs. Therefore, leveraging the latent advantage in the in-situ knowledge base with learning efforts geared towards integration of global scientific knowledge seems necessary for catch-up in agricultural innovation. Moreover, given the proximity to diverse and fast changing agroecologies with unattended productivity problems, firms of the follower countries can play a key role in global agricultural knowledge networks sourcing critical insitu knowledge. Finally strategic technological catch-up of both public and private sector actors in emerging countries is essential in view of climate change, resource degradation and growing sustainability concerns.

25 This is monitored via a 'Compliance assurance programs' (CAP). The Agricultural Biotechnology Stewardship Technical Committee, a consortium of Bt corn registrants, submits an annual CAP report to the U.S. Environmental Protection Agency describing industry-coordinated compliance assurance efforts for Bt traits. This of course is in collaboration with growers associations and/or farmers associations. 
MNEs will do well in localization of radical innovations by focusing on legitimacy construction across the stages of localization of innovation. This involves mapping out the outreach strategies with concerned stakeholders in the innovation system and build trust with potential challengers. The same actors may also be part of a mutually benefiting legitimacy strategy. Collaboration should consider the potential of the local partner in directly or indirectly the costs of legitimacy construction. As a consequence, partner selection among local firms and contract design for collaboration should be determined by the latter's potential for sharing the costs of establishing legitimacy. In sum, localization strategies must go beyond wooing the potential consumers to create legitimacy through strategic interactions with emerging country players.

To conclude, the theoretical motivation of the thesis accords with the idea that the area of evolutionary economics, wherein the biological concepts of variance and selection are so far 'applied', should integrate them 'literally' into discussions of technological evolution in bio-economy (Phillips and $\mathrm{Su}, 2007$ ). This is because both Ecology and economic actors combinely determine the outcomes of a technology transition. While the play of economic actors' may be predictable based on the assumption that they are driven by maximization of self-interest, only the short run responses of Ecology can be forecast based on the existing science base due to complexity. This is an important aspect often not emphasized in explaining the underlying processes of technology transitions towards sustainability. At the same time, while the 'systemic' approach has been used earlier to explain the dynamics of agricultural innovation, the application of concepts such as technology paradigm shifts within agricultural production is rare. The thesis contributes to this gap.

From the policy perspective, major technological transitions usually entail a transformation in the way that an underlying system of economic actors self-organises itself to work with the new technologies. These self-organizing adjustments in the system are reflected not only via the strategies of economic actors but also through ecological responses. This idea is important to drive the system towards sustainability, particularly in the sectors of bio-economy where natural pests, viruses and physical elements such as soil, water and air are part of the production. The thesis by incorporating the above argument in the analysis contributes to science, technology and innovation as well as agricultural policy discussions.

For future research, the geographical context can be expanded to compare and contrast other country experiences with technology transitions. The theoretical construct on technology paradigm shifts can be further refined to model economic behaviour of agents and ecological responses, and can be tested via simulation. Evolution of technological trajectories within the technological space can be empirically tested using patents and publications. With respect to addressing controver- 
sies, scientific publications can used to trace the differences of opinion on emerging technologies such as GM crops and measure them quantitatively using text parsing techniques and citation network analysis. These will be taken into consideration for future research. 



\section{Societal Relevance}

While agricultural production in general contributes to the progress of societies, food production in particular is a socio-economic, political and cultural issue around which societies revolve. In some nations livelihoods of millions are directly dependent on the sector while in others the sector's success is important for economic growth, employment and export revenue. Technical change in agriculture contributed to productivity increase in the sector across nations.

Major technological breakthroughs in crop production technologies or practices may entail uncertainty in terms of sustainability. Sustainability is based on economic as well as environmental outcomes of technologies and their implementation by farmers. At the same time technological progress in the sector poses peculiar challenges for developing country public sector laboratories and seed companies in order to adapt and implement these technologies. This catch up is necessary for not only implementing the new technologies but also to develop capabilities to be able to produce them in the changing context of globalization.

In particular, the advent of radical technologies in the form of genetically modified crops has split up the global agricultural order into two groups wherein European Union and US take opposing standpoints. While EU by and large prefers applying precautionary principle with respect to GM crops US follows its tradition of supporting radical innovations albeit with a good regulatory regime. Developing countries are caught in quandary facing the dilemma whether or not to adopt the GM crops while climate change continues to affect their yields and population keeps growing. The thesis takes a fair and neutral perspective in the presence of these great divides between across the player groups in the agricultural sector across the world.

The primary objective of the thesis is to answer the broad question: What are the drivers of sustainability and technological catch-up in the context of major transitions in crop production technologies? While answering this question an attempt is made to step into the shoes of multiple key players in the innovation system.

The contribution of the thesis to society is multi fold. The findings inform agricultural policy experts in emerging countries in R\&D, extension, regulation and S\&T policy perspectives. The adoption and implementation practices of farmers in India, in the face of diffusion of radical technologies provided key empirical insights. The analysis also informs private and public actors in emerging countries on the possible strategies to effectively catch up with advanced crop production technologies. Finally it also informs multinational firms attempting to contribute towards development via investments in localizing radical agricultural innovations in emerging countries. 



\section{Bibliography}

Cost of Cultivation/Production \& Related Data.Department of Economics and Statistics, Ministry of Agriculture, Government of India.

Cotton Statistics.Cotton Corporation of India.

ABRAMOVITZ, M. 1986. Catching up, forging ahead, and falling behind. Journal of Economic history, 46, 385-406.

ACHARIA, B. 2012. 37th Report on Cultivation of Genetically Modified Food Crops - Prospects and EffectsNew Delhi: Lok Sabha Secretariat, Fifteenth Lok Sabha

ACHARIA, B. 2014.59th Report on Cultivation of Genetically Modified Food Crops - Prospects and Effects \{Action Taken by the Government on the Observations/Recommendations contained in the Thirty-seventh Report of the Committee on Agriculture (2011-2012)\}. New Delhi: Lok Sabha Secretariat, Fifteenth Lok Sabha

AGGARWAL, P., BANDYOPADHYAY, S., PATHAK, H., KALRA, N., CHANDER, S. \& KUMAR, S. 2000. Analysis of yield trends of the rice-wheat system in north-western India. Outlook on Agriculture, 29, 259-268.

AGGARWAL, P. K., JOSHI, P. K., INGRAM, J. S. I. \& GUPTA, R. K. 2004. Adapting food systems of the IndoGangetic plains to global environmental change: key information needs to improve policy formulation. Environmental Science \& Policy, 7, 487-498.

AGORAMOORTHY, G. 2008. Can India meet the increasing food demand by 2020? Futures, 40, 503-506.

ALTIERI, M. A. 2005. The myth of coexistence: why transgenic crops are not compatible with agroecologically based systems of production. Bulletin of Science, Technology \& Society, 25, 361-371.

AMIN, A. \& COHENDET, P. 2004. Architectures of knowledge: Firms, capabilities, and communities, Oxford University Press.

ARORA, A. \& BANSAL, S. 2011. Diffusion of Bt Cotton in India: Impact of Seed Prices and Varietal Approval. Applied Economic Perspectives and Policy, 34, 102-118.

ARTHUR, W. B. 1989. Competing Technologies, Increasing Returns, and Lock-In by Historical Events. The Economic Journal, 99, 116.

ARTHUR, W. B. 1990. Positive Feedbacks in the Economy.Sci Am, 262, 92-99.

ARZA, V. \& VAN ZWANENBERG, P. 2014. The Politics of Technological Upgrading: International Transfer to and Adaptation of GM Cotton in Argentina. World Development, 59, 521-534.

BARIK, A. 2010. Cotton Statistics at a glance. Mumbai, Maharashtra: Directorate of Cotton Development, Ministry of Agriculture, Government of India.

BARWALE, R. B., GADWAL, V. R. \& ZEHR, U. 2004. Prospects for Bt cotton technology in India. AgBioforum, 7, 23-26.

BENNETT, M., KAMBHAMPATI, U., MORSE, S. \& ISMAEL, Y. 2004.Farm-Level Economic Performance of Genetically Modified Cotton in Maharashtra.Review of Agricultural Economics, 28, 59-71.

BENNETT, R., ISMAEL, Y. \& MORSE, S. 2005. Explaining contradictory evidence regarding impacts of genetically modified crops in developing countries.Varietal performance of transgenic cotton in India.J. Agric. Sci., 143, 35-41.

BENNETT, R., KAMBHAMPATI, U., MORSE, S. \& ISMAEL, Y. 2006.Farm-Level Economic Performance of Genetically Modified Cotton in Maharashtra, India.Rev Agricultural Economics, 28, 59-71.

BHALLA, G. S. \& GURMAIL, S. 2010. Final Report on Planning Commission Project Growth of Indian Agriculture : A District Level Study. Planning Commission of India Project Report.

BIRKINSHAW, J. \& HOOD, N. 1998. Multinational subsidiary evolution: capability and charter change in foreign-owned subsidiary companies. Academy of management review, 23, 773-795.

BISANG, R. 2011. Agro y recursosnaturalesen la Argentina:¿enfermedadmaldita o desafío a la inteligenciacolectiva? BoletínInformativo de Techint, 336, 63-83.

BRANSTETTER, L. G., FISMAN, R. \& FOLEY, C. F. 2006. Do stronger intellectual property rights increase international technology transfer? Empirical evidence from US firm-level panel data. The Quarterly Journal of Economics, 121, 321-349.

BRAUN, J. V., GULATI, A., HAZELL, P., ROSEGRANT, M. W. \& RUEL, M. 2005. Indian Agriculture and Rural Development: Strategic Issues and Reform Options. International Food Policy Researcg Institute Publication. 
BUTTEL, F. H., KENNEY, M. \& KLOPPENBURG JR, J. 1985. From Green Revolution to Biorevolution: Some observations on the changing technological bases of economic transformation in the Third World. Economic Development and Cultural Change, 34, 31-55.

BYERLEE, D. \& FISCHER, K. 2002.Accessing modern science: policy and institutional options for agricultural biotechnology in developing countries.World Development, 30, 931-948.

BYERLEE, D. \& MURGAI, R. 2001. Sense and sustainability revisited: the limits of total factor productivity measures of sustainable agricultural systems. Agricultural Economics, 26, 227-236.

CANTWELL, J. \& IAMMARINO, S. 2003. Multinational corporations and European regional systems of innovation, Routledge.

CARLSSON, B. \& STANKIEWICZ, R. 1991.On the nature, function and composition of technological systems.Journal of Evolutionary Economics, 1, 93-118.

CHOUDHARY, B. \& GAUR, K. 2010.Bt cotton in India: A country profile. ISAAA Series of Biotech Crop Profiles. ISAAA: Ithaca, NY.

COELLI, T. J. \& RAO, D. S. P. 2005. Total factor productivity growth in agriculture: a Malmquist index analysis of 93 countries, 1980-2000. Agricultural Economics, 32, 115-134.

COHEN, W. M. \& LEVINTHAL, D. A. 1990. Absorptive capacity: a new perspective on learning and innovation. Administrative science quarterly, 128-152.

COWAN, R. 1990. Nuclear Power Reactors: A Study in Technological Lock-in. J. Eco. History, 50, 541-567.

COWAN, R. 1996. Escaping lock-in: the case of the electric vehicle.Technological forecasting and social change, 53, 61-79.

COWAN, R. \& GUNBY, P. 1996. Sprayed to Death: Path Dependence, Lock-in and Pest Control Strategies.The Economic Journal, 106, 521.

DAVID, P. A. 1985. Clio and the Economics of QWERTY.The American economic review, 332-337.

DEEGAN, C. 2002. Introduction: the legitimising effect of social and environmental disclosures-a theoretical foundation. Accounting, Auditing \& Accountability Journal, 15, 282-311.

DHILLON, B., KATARIA, P. \& DHILLON, P. 2010. National food security vis-à-vis sustainability of agriculture in high crop productivity regions.Current Science, 98, 1-4.

DORIN, B. \& LANDY, F. 2002.Agriculture etl'Alimentation de l'Inde. Les Vertesannées (1947-2001), Versailles, INRA Editions.

DOSI, G. 1982. Technological paradigms and technological trajectories.Research Policy, 11, 147-162.

DOSI, G. 1988. Sources, procedures, and microeconomic effects of innovation.Journal of economic literature, 26, 1120-1171.

DOWLING, J. \& PFEFFER, J. 1975. Organizational Legitimacy: Social Values and Organizational Behavior. The Pacific Sociological Review, 18, 122-136.

DYSON, T. 1999. World food trends and prospects to 2025.Proceedings of the National Academy of Sciences, 96, 5929-5936.

EISENHARDT, K. M. 1989. Building theories from case study research.Academy of management review, 532-550.

ERNST, D. 2001. Global Production Networks and Industrial Upgrading - A Knowledge-Centered Approach. Economics Study Area Working Papers.East-West Center, Economics Study Area.

ETC-GROUP 2013a. Gene Giants Seek "Philanthrogopoly”. ETC Group Communique. ETC Group.

ETC-GROUP 2013b. Putting the Cartel before the Horse...and Farm, Seeds, Soil, Peasants, etc. Who Will Control Agricultural Inputs, 2013? ETC Group Communique. ETC Group.

EVENSON, R. E. 2002. From the Green Revolution to the Gene Revolution.In: EVENSON, R. E., SANTANIELlO, V. \& ZILBERMAN, D. (eds.) Economic and Social Issues in Agricultural Biotechnology. Wallingford: CABI Publications.

EVENSON, R. E. \& GOLLIN, D. 2003.Assessing the impact of the Green Revolution, 1960 to 2000.Science, 300, 758-762.

FERNANDEZ-STARK, K., BAMBER, P. \& GEREFFI, G. 2011. The offshore services value chain: upgrading trajectories in developing countries. International Journal of Technological Learning, Innovation and Development, 4, 206-234.

FORESTS, M. O. E. A. 2010. Note on the Decision on Commercialization of BtBrinjal. Ministry of Environment and Forests, Government of India. 
FRANKEL, F. R. 1971. India's green revolution. Economic gains and political costs, Princeton, NJ: Princeton University Press; London: Oxford University Press.

FRANKEL, F. R. 1973. The politics of the green revolution: Shifting patterns of peasant participation in India and Pakistan. Food, Population and Employment, 120-51.

FREEMAN, C. \& SOETE, L. 1997.The economics of industrial innovation, Psychology Press.

FULTON, M. \& GIANNAKAS, K. 2001.Agricultural biotechnology and industry structure.AgBioForum, 4, 137-151.

GANDHI, V. P. \& NAMBOODIRI, N. 2009. Economics of Bt cotton vis-a-vis non-Bt cotton in India:A study of four major cotton growing states. Centre for Management in Agriculture, Indian Institute of Management Ahmedabad.

GEAC 2013. Year wise list of commercially released varieties of Bt cotton hybrids by GEAC (Year 2002upto May, 2012). Genetic Engineering Appraisal Committee, India.

GEELS, F. 2002. Technological transitions as evolutionary reconfiguration processes: a multi-level perspective and a case-study. Research Policy, 31, 1257-1274.

GEELS, F. 2004. From sectoral systems of innovation to socio-technical systems.Research Policy, 33, 897-920.

GEELS, F. 2005. Processes and patterns in transitions and system innovations: Refining the coevolutionary multi-level perspective. Technological Forecasting and Social Change, 72, 681-696.

GEELS, F. \& KEMP, R. 2007. Dynamics in socio-technical systems: Typology of change processes and contrasting case studies. Technology in Society, 29, 441-455.

GEELS, F. \& SCHOT, J. 2007.Typology of sociotechnical transition pathways.Research Policy, 36, 399-417.

GEREFFI, G. \& KAPLINSKY, R. 2001.The value of value chains: spreading the gains from globalisation, Institute of Development Studies.

GEREFFI, G. \& KORZENIEWICZ, M. 1994.Commodity Chains and Global Capitalism, ABC-CLIO.

GLASER, B. G. \& STRAUSS, A. L. 2009.The discovery of grounded theory: Strategies for qualitative research, Transaction Publishers.

GÓMEZ-LIMÓN, J. A. \& SANCHEZ-FERNANDEZ, G. 2010.Empirical evaluation of agricultural sustainability using composite indicators.Ecological Economics, 69, 1062-1075.

GRIFFITH, R. \& MILLER, H. 2011. Innovation in China: the rise of Chinese inventors in the production of knowledge. Institute for Fiscal Studies Working Paper W, 11.

GRUÈRE, G. \& SENGUPTA, D. 2011.Bt cotton and farmer suicides in India: an evidence-based assessment. The journal of development studies, 47, 316-337.

GRUÈRE, G. P., MEHTA-BHATT, P. \& SENGUPTA, D. 2008.Bt cotton and farmer suicides in India: Reviewing the evidence, Intl Food Policy Res Inst.

HALL, J., BACHOR, V. \& MATOS, S. 2014. Developing and Diffusing New Technologies. California Management Review, 56, 98-117.

HALL, J., MATOS, S. \& LANGFORD, C. H. 2008. Social exclusion and transgenic technology: the case of Brazilian agriculture. Journal of Business ethics, 77, 45-63.

HALL, J., MATOS, S., SILVESTRE, B. \& MARTIN, M. 2011. Managing technological and social uncertainties of innovation: The evolution of Brazilian energy and agriculture. Technological Forecasting and Social Change, 78, 1147-1157.

HALL, J. K. \& MARTIN, M. J. C. 2005. Disruptive technologies, stakeholders and the innovation valueadded chain: a framework for evaluating radical technology development. R\&D Management, 35, 273-284.

HANSEN, J. W. 1996. Is agricultural sustainability a useful concept? Agricultural Systems, 50, 117-143.

HANUR, V. 2011.Bt resistance in Helicoverpa species: Indian policy needs urgent revision. Economic and Political Weekly, 101, 470-471.

HENRY, C. 2011. Scientific uncertainity and fabricated uncertainity.The Stockholm Seminars, The Royal Swedish Academy of Sciences.

HERRING, R. 2013. Reconstructing facts in Bt Cotton: why scepticism fails. Econ PolitWkly, 48, 63-6.

HERRING, R. J. 2008. Whose numbers count? Probing discrepant evidence on transgenic cotton in the Warangal district of India.International Journal of Multiple Research Approaches, 2, 145-159. 
HIRSCH-KREINSEN, H., JACOBSON, D., LAESTADIUS, S. \& SMITH, K. 2005.Low and medium technology industries in the knowledge economy: the analytical issues. Peter Lang.

HOBBS, P. \& MORRIS, M. L. 1996.Meeting South Asia's future food requirements from rice-wheat cropping systems: priority issues facing researchers in the post-Green Revolution era, International Maize and Wheat Improvement Center.

HUGHES, T. P. 1987. The evolution of large technological systems. The social construction of technological systems: New directions in the sociology and history of technology, 51-82.

HUMPHREY, J. \& SCHMITZ, H. 2000.Governance and upgrading: linking industrial cluster and global value chain research, Institute of Development Studies Brighton.

HUMPHREY, J. \& SCHMITZ, H. 2002a.Developing country firms in the world economy: Governance and upgrading in global value chains, INEF.

HUMPHREY, J. \& SCHMITZ, H. 2002b. How does insertion in global value chains affect upgrading in industrial clusters? Regional studies, 36, 1017-1027.

IGMORIS 2014.Indian GMO Research Information System.Department of Biotechnology, Ministry of Science \& Technology, Government of India.

IIZUKA, M. 2007. Global standards and local producers: knowledge governance and the rise of the Chilean salmon industry.University of Sussex.

ISC 2013.Knowledge Report - Indian Seed Industry Current Scenario \& Future Prospects.National Seed Association of India.

ISF-WEBSITE 2013.Seed statistics - Domestic Seed Markets.International Seed Federation.

JALONEN, H. 2011. The uncertainty of innovation: a systematic review of the literature. jmr, 4.

JAMES, C. 2013. Global Status of Commercialized Biotech/GM Crops: 2013 ISAAA Brief No 46-2013. ISAAA: Ithaca, NY.

JANAIAH, A., OTSUKA, K. \& HOSSAIN, M. 2005. Is the Productivity Impact of the Green Revolution in Rice Vanishing? Empirical Evidence from TFP Analysis.Economic and Political Weekly, 5596-5600.

JAYARAMAN, K. S. 2000. India Okays GM cotton.Nature Biotechnology, 18, 582.

JAYARAMAN, K. S. 2001a. Illegal Bt cotton in India haunts regulators. Nature Biotechnology, 19, 1090.

JAYARAMAN, K. S. 2001b. India backtracks on Bt cotton. Nature Biotechnology, 19, 703.

JAYARAMAN, K. S. 2003. India dawdles over Bt-cotton. Nature Biotechnology, 21, 590-1.

JAYARAMAN, K. S. 2004. Illegal seeds overtake India's cotton fields. Nature Biotechnology, 22, 1333-4.

JAYARAMAN, K. S. 2012. India investigates Bt cotton claims: Research council launches probe into how Monsanto gene ended up in its indigenous transgenic cotton. Nature, 15 February 2012.

JAYARAMAN, K. S., FOX, J. L., JIA, H. \& ORELLANA, C. 2005. Indian Bt gene monoculture, potential time bomb.Nature Biotechnology, 23, 158.

K.VENKATESHWARLU. 2012.The Hindu, 19 Dec 2012.

KAPLINSKY, R. \& MORRIS, M. 2001.A handbook for value chain research, IDRC.

KATHAGE, J. \& QAIM, M. 2012. Economic impacts and impact dynamics of Bt (Bacillus thuringiensis) cotton in India. Proceedings of the National Academy of Sciences, 109, 11652-11656.

KATZ, J. 2006. Salmon farming in Chile.In: CHANDRA, V. (ed.) Technology, Adaptation, and Exports: How Some Developing Countries Got It Right.World Bank.

KEMP, R. 1994. Technology and the transition to environmental sustainability.Futures, 26, 1023-1046.

KEMP, R. 1998. The diffusion of biological waste-water treatment plants in the Dutch food and beverage industry. Environmental and Resource Economics, 12, 113-136.

KEMP, R., SCHOT, J. \& HOOGMA, R. 1998. Regime shifts to sustainability through processes of niche formation: The approach of strategic niche management. Technology Analysis \& Strategic Management, 10, 175-198.

KEMP, R. \& SOETE, L. 1992. The greening of technological progress: an evolutionary perspective. Futures, 24, 437-457.

KIRESUR, V. R. \& ICHANGI, M. 2011. Socio-Economic Impact of Bt Cotton - A Case Study of Karnataka. Agricultural Economics Research Review, 24, 67-81.

KLOPPENBURG, J. 2014. Re-purposing the master's tools: the open source seed initiative and the struggle for seed sovereignty.Journal of Peasant Studies, 41, 1225-1246. 
KONIG, A., COCKBURN, A., CREVEL, R., DEBRUYNE, E., GRAFSTROEM, R., HAMMERLING, U., KIMBER, I., KNUDSEN, I., KUIPER, H. A. \& PEIJNENBURG, A. 2004. Assessment of the safety of foods derived from genetically modified (GM) crops. Food and Chemical Toxicology, 42, 1047-1088.

KRANTHI, K., KRANTHI, S., KHADI, B. \& JAIN, K. Challenges in detecting GM crops.World Cotton Research Conference-4, Lubbock, Texas, USA, 10-14 September 2007., 2007. International Cotton Advisory Committee (ICAC).

KRANTHI, K. R. 2012. Bt Cotton Q\&A. Pune: Central Institute for cotton Research, Nagpur.

KRISHNA, V. V. \& QAIM, M. 2012. Bt cotton and sustainability of pesticide reductions in India. Agricultural Systems, 107, 47-55.

KULKARNI, N. 2003. Spurious Bt-cottonseeds - Is it the right way? BioSpecturm the business of bioscience.Biospectrum.

KUMAR, P. \& JHA, D. 2005. Measurement of Total Factor Productivity Growth of Rice in India: Implications for Food Security and Trade. In: JOSHI, P. K., PAL, S., BIRTHAL, P.S. AND BANTILAN, M.C.S (ed.) Impact of Agricultural Research: Post-Green Revolution Evidence from IndiaNCAP New Delhi.

KUMAR, P. \& MITTAL, S. 2006. Agricultural Productivity Trends in India : Sustainability Issues. Agricultural Economics Research Review, 19, 71-88.

LEE, K. 2013. Schumpeterian Analysis of Economic Catch-up: Knowledge, Path-creation, and the Middleincome Trap, Cambridge University Press.

LEE, K. \& LIM, C. 2001. Technological regimes, catching-up and leapfrogging: findings from the Korean industries. Research policy, 30, 459-483.

LOGANATHAN, R., BALASUBRAMANIAN, R., MANI, K. \& GURUNATHAN, S. 2009. Productivity and Profitability Impact of Genetically Modified Crops - An Economic Analysis of Bt Cotton Cultivation in Tamil Nadu. Agricultural Economics Research Review, 22, 331-340.

LUNDVALL, B.-Å. 1992. National systems of innovation: An analytical framework, London: Pinter.

LYNAM, J. \& HERDT, R. 1989. Sense and sustainability: Sustainability as an objective in international agricultural research. Agricultural Economics, 3, 381-398.

MALERBA, F. 2002. Sectoral systems of innovation and production.Research Policy, 31, 247-264.

MALERBA, F. \& NELSON, R. 2011. Learning and catching up in different sectoral systems: evidence from six industries. Industrial and Corporate Change, 20, 1645-1675.

MENON, M. 2014. Panel clears field trials for 4 GM crops. The Hindu, July 192014.

MOEF 2010. Note on the Decision on Commercialization of BtBrinjal. Ministry of Environment and Forests, Government of India.

MONSANTO. 2009. Pink Bollworm Resistance to GM Cotton in India [Online]. Available: http://www.monsanto.com/newsviews/pages/india-pink-bollworm.aspx [Accessed 21-06-2015.

MORSE, S., BENNETT, R. \& ISMAEL, Y. 2005.Comparing the performance of official and unofficial genetically modified cotton in India.AgBioForum, 8, 1-6.

MUKHERJEE, A. N. \& KURODA, Y. 2003. Productivity growth in Indian agriculture: is there evidence of convergence across states? Agricultural Economics, 29, 43-53.

MURGAI, R., ALI, M. \& BYERLEE, D. 2001. Productivity growth and sustainability in post-Green Revolution agriculture: the case of the Indian and Pakistan Punjabs. The World Bank Research Observer, 16, 199-218.

MURPHY, J., LEVIDOW, L. \& CARR, S. 2006. Regulatory Standards for Environmental Risks Understanding the US-European Union Conflict over Genetically Modified Crops. Social Studies of Science, 36, 133-160.

MURUGKAR, M., RAMASWAMI, B. \& SHELAR, M. 2006. Liberalization, biotechnology and the private seed sector: The Case of India's cotton seed market. Indian Statistical Institute, Planning Unit, New Delhi Discussion Papers, 06-05.

MURUGKAR, M., RAMASWAMI, B. \& SHELAR, M. 2007. Competition and monopoly in Indian cotton seed market. Economic and Political weekly, 3781-3789.

NAGARAJAN, S. 2005. Can India produce enough wheat even by 2020.Curr Sci, 89, 1467-1471. 
NAGRARE, V. S., KRANTHI, S., BIRADAR, V. K., ZADE, N. N., SANGODE, V., KAKDE, G., SHUKLA, R. M., SHIVARE, D., KHADI, B. M. \& KRANTHI, K. R. 2009. Widespread infestation of the exotic mealybug species, Phenacoccussolenopsis (Tinsley) (Hemiptera: Pseudococcidae), on cotton in India. Bull. Entomol.Res., 99, 537.

NANDKUMAR, A. \& SRIKANTH, K. 2011.Patently Different? How Does the Strength of Patents Influence Globalization of R\&D? Empirical Evidence from the 2004 Indian Patent Reforms.

NARAYANAMOORTHY, A. \& KALAMKAR, S. S. 2006. Is Bt cotton cultivation economically viable for Indian farmers? An empirical analysis.Economic and Political Weekly, 2716-2724.

NELSON, R. 1993. National Innovation Systems : A Comparative Analysis: A Comparative Analysis, Oxford University Press, USA.

NELSON, R. \& ROSENBERG, N. 1993.Technical innovation and national systems.National innovation systems: a comparative analysis. Oxford University Press, Oxford.Oxford University Press.

NELSON, R. \& WINTER, S. 1982. Introduction.An evolutionary theory of economic change.The Belknap Press.

NELSON, R. R. 1959. The Simple Economics of Basic Scientific Research.The Journal of Political Economy, 67, 297-306.

NEWELL, P. 2007. Biotech Firms, Biotech Politics Negotiating GMOs in India. The Journal of Environment \& Development, 16, 183-206.

NEWELL, P. 2009. Bio-hegemony: the political economy of agricultural biotechnology in Argentina. Journal of Latin American Studies, 41, 27-57.

OECD 2013. Interconnected Economies: Benefiting from global value chains - Synthesis Report. Synt. Paris: OECD.

OLMSTEAD, A. L. \& RHODE, P. W. 2008.Creating abundance: Biological innovation and American agricultural development, Cambridge University Press Cambridge.

PAOLETTI, M. G. \& PIMENTEL, D. 1995.The environmental and economic costs of herbicide resistance and host-plant resistance to plant pathogens and insects.Technological Forecasting and Social Change, 50, 9-23.

PARAYIL, G. 1991. Technological change as a problem-solving activity.Technological Forecasting and Social Change, 40, 235-247.

PARAYIL, G. 1992. The Green Revolution in India: A Case Study of Technological Change. Technology and Culture, 33, 737.

PARAYIL, G. 2003. Mapping technological trajectories of the Green Revolution and the Gene Revolution from modernization to globalization.Research Policy, 32, 971-990.

PARDEY, P. G., ALSTON, J. M. \& PIGGOTT, R. R. 2006.Agricultural R and D in the Developing World, Free downloads from IFPRI.

PARSAI, G. Mortality in sheep, goat after grazing on Bt cotton fields. The Hindu, May 212006.

PAVITT, K. 1984. Sectoral patterns of technical change: towards a taxonomy and a theory. Research policy, 13, 343-373.

PENG, S., CASSMAN, K. G., VIRMANI, S., SHEEHY, J. \& KHUSH, G. S. 1999. Yield potential trends of tropical rice since the release of IR8 and the challenge of increasing rice yield potential. Crop Science, 39, 1552-1559.

PENG, S., HUANG, J., CASSMAN, K. G., LAZA, R. C., VISPERAS, R. M. \& KHUSH, G. S. 2010. The importance of maintenance breeding: A case study of the first miracle rice variety-IR8. Field crops research, 119, 342-347.

PEREZ, C. 2004. Technological revolutions, paradigm shifts and socio-institutional change. Globalization, economic development and inequality: An alternative perspective, 217-242.

PEREZ, C. 2009. Technological revolutions and techno-economic paradigms.Cambridge Journal of Economics, bep051.

PEREZ, C. \& SOETE, L. 1988.Catching up in technology: entry barriers and windows of opportunity.Technical change and economic theory. London: Francis Pinter.

PILLANIA, R. K. 2011. The state of research on technological uncertainties, social uncertainties and emerging markets: A multidisciplinary literature review. Technological Forecasting and Social Change, 78, 1158-1163. 
PINGALI, P. \& SHAH, M. 1999. Rice-wheat cropping system in the Indo-Gangetic plains: policy redirections for sustainable resource use. Sustaining rice-wheat production systems: socioeconomic and policy issues. Rice-Wheat Consortium Paper series, 5, 1-12.

PINGALI, P. L. 2012. Green Revolution: Impacts, limits, and the path ahead. Proceedings of the National Academy of Sciences, 109, 12302-12308.

PINGALI, P. L. \& ROSEGRANT, M. W. 1994.Confronting the environmental consequences of the Green Revolution in Asia.EPTD discussion papers, 2.

PINSTRUP-ANDERSEN, P. \& HAZELL, P. B. R. 1985.The impact of the green revolution and prospects for the future.Food Reviews International, 1, 1-25.

POSSAS, M. L., SALLES-FILHO, S. \& DA SILVEIRA, J. 1996. An evolutionary approach to technological innovation in agriculture: some preliminary remarks. Research Policy, 25, 933-945.

PRAHALAD, C. K. \& MASHELKAR, R. A. 2010. Innovation's holy grail. Harvard Business Review, 88, 132-141.

PRAY, C., RAMASWAMI, B. \& KELLEY, T. 2001. The impact of economic reforms on R\&D by the Indian seed industry.Food Policy, 26, 587-598.

PRAY, C. E. \& NAGARAJAN, L. 2012. Innovation and research by private agribusiness in India.IFPRI Discussion Paper 01181

PRAY, C. E. \& NAGARAJAN, L. 2014. Innovations in Indian Seed/Biotech Industry.Innovation in India: Combining Economic Growth with Inclusive Development.

PTI. 2014. No ban on GM crop field trials: Javadekar. The Hindu, Nov 262014.

QAYUM, A. \& SAKKHARI, K. 2006.Bt cotton in Andhra Pradesh - A three-year assessment. The first ever sustained independent scientific study of Bt cotton in India. Deccan Development Society.

RAGHURAM, N. 2002. India joins the GM club. Trends in Plant Science, 7, 322-323.

RAMANI, S. V. \& RICHARD, A. 1993. Decision, irreversibility and flexibility: The irreversibility effect reexamined. Theory and decision, 35, 259-276.

RAMANJANEYULU, G. \& KURUGANTI, K. 2006.Bt Cotton in India: Sustainable Pest Management? Economic and Political weekly, 561-563.

RAMASWAMI, B. \& PRAY, C. E. 2007.India : Confronting the Challenge The Potential of Genetically Modified Crops for the Poor. The gene revolution: GM crops and unequal development, 156.

RIP, A. \& KEMP, R. 1998. Technological change.In: RAYNER, S. \& MALONE, L. (eds.) Human choice and climate change. Washington D.C.: Resources and Technology, Batelle Press

RODELL, M., VELICOGNA, I. \& FAMIGLIETTI, J. S. 2009.Satellite-based estimates of groundwater depletion in India.Nature, 460, 999-1002.

ROSEGRANT, M. W. \& EVENSON, R. E. 1995. Total factor productivity and sources of long-term growth in Indian agriculture. International Food Policy Research Institute (IFPRI).

SADASHIVAPPA, P. \& QAIM, M. 2009.Bt cotton in India: development of benefits and the role of government seed price interventions. Agbioforum, 12, 172-183.

SAHAI, S. \& RAHMAN, S. 2003. Performance of Bt cotton: Data from first commercial crop. Economic and Political Weekly, 3139-3141.

SAHAI, S. \& REHMAN, S. 2004. Bt-Cotton performance 2003-2004: fields swamped with illegal variants. Economic and Political Weekly, 39, 2673-2674.

SAHAL, D. 1985. Technological guideposts and innovation avenues.Research Policy, 14, 61-82.

SARKAR, B., PATRA, A. K., PURAKAYASTHA, T. \& MEGHARAJ, M. 2009. Assessment of biological and biochemical indicators in soil under transgenic Bt and non-Bt cotton crop in a sub-tropical environment. Environmental monitoring and assessment, 156, 595-604.

SCHMID, S. \& KOTULLA, T. 2011. 50 years of research on international standardization and adaptation-From a systematic literature analysis to a theoretical framework. International Business Review, 20, 491-507.

SCHOT, J., HOOGMA, R. \& ELZEN, B. 1994.Strategies for shifting technological systems.Futures, 26, 10601076.

SHELTON, A. M. 2007. Considerations on the Use of Transgenic Crops for Insect Control.Journal of Development Studies, 43, 890-900.

SHIVA, V. 1989.The Violence of The Green Revolution - Ecological Degradation and Political Conflict in Punjab, Dehra Dun, Natraj publisher. 
SHIVA, V. 1991.The violence of Green Revolution: third world agriculture, ecology and politics, Zed Books.

SHIVA, V. 2004. The future of food: countering globalisation and recolonisation of Indian agriculture. Futures, 36, 715-732.

SHIVA, V. \& JAFRI, A. 2004.Failure of GMOs in India (Synthesis/Regeneration, 33/Winter).New Delhi, India: Research Foundation for Science, Technology and Ecology.

SHULIN GU, J. O. A., ANA CÉLIA CASTRO, JEFFREY OROZCO AND RAFAEL DÍAZ 2012. The Agro-food Sector in Catching-up Countries: A Comparative Study of Four Cases. In: FRANCO MALERBA, R. R. N. (ed.)

Economic Development as a Learning Process Variation Across Sectoral Systems.Edward Elgar Publishing.

SINGER, H. W. 1950. The distribution of gains between investing and borrowing countries. The American Economic Review, 40, 473-485.

SINGH, H. \& CHAND, R. 2011. The Seeds Bill, 2011: Some Reflections. Economic \& Political Weekly, 46, 23.

SINGH, R. B. 2000. Environmental consequences of agricultural development: a case study from the Green Revolution state of Haryana, India. Agriculture, Ecosystems \& Environment, 82, 97-103.

SINGH, R. J., AHLAWAT, I. \& SINGH, S. 2013. Effects of transgenic Bt cotton on soil fertility and biology under field conditions in subtropical inceptisol. Environmental monitoring and assessment, 185, 485-495.

SINGLA, R., JOHNSON, P. \& MISRA, S. 2013. Examination of regional-level efficient refuge requirements for Bt cotton in India.

SINHA, S. K. 2001. Architect of the green revolution.The Hindu, November 04.

SOETE, L. 1985. International diffusion of technology, industrial development and technological leapfrogging.World Development, 13, 409-422.

STONE, G. D. 2012. Constructing Facts Bt Cotton Narratives in India. Economic \& Political Weekly, 47, 63.

STONE, G. D., FLACHS, A. \& DIEPENBROCK, C. 2014. Rhythms of the herd: Long term dynamics in seed choice by Indian farmers. Technology in Society, 36, 26-38.

SUBRAMANIAN, A. \& QAIM, M. 2009. Village-wide Effects of Agricultural Biotechnology: The Case of Bt Cotton in India. World Development, 37, 256-267.

SWANSON, T. M. 2002. Biotechnology, agriculture and the developing world: the distributional implications of technological change, Edward Elgar Publishing Ltd.

TEC 2012.Interim Report of the Technical Expert Committee (TEC)of Supreme Court of India.Supreme Court of India.

TEC 2013.Final Report of the Technical Expert Committee (TEC) of Supreme Court of India.Supreme Court of India.

THIES, J. E. \& DEVARE, M. 2007. An ecological assessment of transgenic crops.Journal of Development Studies, 43, 97-129.

UNFAO 2015a.AQUASTAT Database.

UNFAO 2015b.FAOStat Database.

USDA 2015.International Agricultural Productivity.USDA- Economic Research Service.

VANLOQUEREN, G. \& BARET, P. V. 2009. How agricultural research systems shape a technological regime that develops genetic engineering but locks out agroecological innovations. Research Policy, 38, 971-983.

VENKATESWARLU, B. 2001.The Indian biosafety regulations on GMOs under test.GMWATCH, 10 Dec 2001.

VISAWADIA, H. R., FADADU, A. M. \& TARPARA, V. D. 2006. A Comparative Analysis of Production and Marketing of Bt Cotton and Hybrid Cotton in Saurashtra Region of Gujarat State. Agricultural Economics Research Review, 19, 293-300.

YANG, G. \& MASKUS, K. E. 2001.Intellectual property rights, licensing, and innovation in an endogenous product-cycle model.Journal of International Economics, 53, 169-187.

YIN, R. 2002. Case study evaluations: a decade of progress? Evaluation Models, 185-193.

ZHAO, M. 2006. Conducting R\&D in countries with weak intellectual property rights protection.Management Science, 52, 1185-1199.

ZIMMERMAN, M. A. \& ZEITZ, G. J. 2002. BEYOND SURVIVAL: ACHIEVING NEW VENTURE GROWTH BY BUILDING LEGITIMACY. Academy of Management Review, 27, 414-431. 
Eduardo Urias

Improving access to HIV/AIDS treatment in Brazil: When are compulsory licenses effective in price negotiations?

83. FatoumataLamarana Diallo Evaluation of Meal and Deworming Programs for Primary Schools in Rural Senegal

91. Fracesca Guadagno

Why have so few countries industrialised?

90. Daniel Opolot

The evolution of beliefs and strategic behavior

89. Alejandro Lavopa

Structural Transformation and Economic Development: Can Development Traps be Avoided?

88. Jinjin Zhao

Urban water management reform: The case of China

87. Dirk Crass

The Impact of Brands on Innovation and Firm Performance: Empirical Evidence from Germany

86. SamyuktaBhupatiraju

The Geographic Dimensions of Growth and Development

82. Anant Kamath Information Sharing through Informal Interaction in Low-Tech Clusters

81. Flavia Pereira de Carvalho

What we talk about when we talk about Brazilian Mulitantionals: an investigation on Brazilian FDI, economic structure, innovation and the relationship between them

80. Jun Hou

Complementarity in Innovation and Development: A Cross-country Comparison

79. RufinBaghana

Impacts of Government Incentives to R\&D, Innovation and Productivity: A Microeconometric Analysis of the Québec Case

78. Lilia I. Stubrin

High-Tech Activities in Emerging Countries: A Network perspective on the Argentinean biotech activity

2012

85. François Lafond

The evolution of knowledge systems

84. Annalisa Primi

Promoting Innovation in Latin America: What Countries Have Learned (and What They Have Not) in Designing and Implementing Innovation and Intellectual Property Policies

77. Abdul Waheed

Innovation Determinants and Innovation as a Determinant: Evidence from Developing Countries

76. Bilal Mirza

Energy Poverty and Rural Energy Markets in Pakistan 
75. Benjamin Engelstätter

Enterprise Software and Video Games:

An Empirical Analysis

Fulvia Farinelli

Natural Resources, Innovation and Export Growth: The Wine Industry in Chili and Argentina

Rodolfo Lauterbach

Innovation in Manufacturing: From Product Variety and Labor Productivity Growth to Economic Development in Chile

74. Kirsten Wiebe

Quantitative Assessment of Sustainable Development and Growth in SubSaharan Africa.

73. Julio Miguel Rosa

Organizational Strategies, Firms' Performance and Spatial Spillovers. The Canadian Case in Research and Development

Johannes Wilhelmus Marie Boels Joseph Schumpeter, honderdjaareconomischeontwikkeling. Eenhistorischtheoretische beschouwing.

2011

72. Daniel Vertesy

Interrupted Innovation: Emerging economies in the structure of the global aerospace industry.

71. Tina Saebi

Successfully managing alliance portfolios: an alliance capability view.

70. Nora Engel

Tuberculosis in India - A case of innovation and control.

69. Evans Mupela

Connectivity and growth in Sub-Saharan Africa: The role of communication satellites
68. NantawanKwanjai

Cross cultural intelligence amid intricate cultural webs: A tale of the UnDutchables in the land of 1002 smiles

67. Lina Sonne

Innovation in Finance to Finance Innovation: Supporting pro-poor entrepreneurbased innovation

2010

66. Fernando Santiago

Human Resources Management Practices and Learning for Innovation in Devel oping Countries: Pharmaceutical Firms in Mexico

65. ZakariaBabutsidze

Essays on Economies with Heterogenous Interacting Consumers

64. Bertha Vallejo

Learning and Innovation Under Changing Market Conditions: The Auto Parts Industry in Mexico

63. DonatusAyitey

Technical Change, Competitiveness and Poverty Reduction: A Study of the Ghanaian Apparel Industry

62. Sergey Fillipov

Multinational Subsidiary Evolution: Corporate Change in New EU Member States

61. AselDoranova

Technology Transfer and Learning under the Kyoto regime; Exploring the Technological Impact of CDM projects in developing countries

2009

60. Alexis Habiyaremye

From Primary Commodity Dependence to Diversification and Growth". "Absorptive Capacity and Technological Catch Up in Botswana and Mauritius".

59. YosephGetachew

The Role of Public Capital in Economic Development 
58. Sandra Leitner

Embodied Technological Change and Patterns of Investment in Austrian Manufacturing

57. SemihAkçomak

The Impact of Social Capital on Economic and Social Outcomes

56. Abraham Garcia

The Role of Demand in Technical Change

55. Saurabh Arora

Coherence in socio-technical systems: a network perspective on the innovation process

2008

54. RutgerDaems

Medicines for the developing world

53. Johannes Hanel

Assessing Induced Technology: Sombart's Understanding of Technical Change in the History of Economics

52. RifkaWeehuizen

Mental Capital: the economic significance of mental health

51. Danielle Cloodt

The relationship between R\&D partnership formation, social embeddedness and innovative performance

50. Sabine Fuss

Sustainable Energy Development under Uncertainty

2007

49. Tobias Kronenberg

Reconciling Environmental Conservation with Economic Prosperity: The Feasibility of Double Dividends in the Short and Long Run

48. ViktoriaKravtsova

Assessing the Impact of Foreign Direct Investment in Transition Economies
47. Suhail Sultan

The Competitive Advantage of Small and Medium Sized Enterprises: The Case of Jordan's Natural Stone Industry

2006

46. BulatSanditov

Essays on Social Learning and Imitation

45. MamataParhi

Dynamics of New Technology Diffusion: A Study of the Indian Automotive Industry

44. Andreas Reinstaller

Social structures and the innovation process: Their role in the demand of firms and consumers

43. Rose Kiggundu

Innovation systems and development: the journey of a Beleaguered Nile Perch Fishery in Uganda

42. Thomas Pogue

The Evolution of Research Collaboration in South African Gold Mining: 1886-1933

41. Geoffrey Gachino

Foreign Direct Investment, Spillovers and Innovation: The Case of Kenyan Manufacturing Industry

40. ÖnderNomaler

Technological Change, International Trade and Growth: An Evolutionary, Multi-Agents-Based Modeling Approach

2005

39. SamiaSatti Osman Mohamed-Nour Change and Skill Development in the Arab Gulf Countries

38. EladHarison Intellectual Property Rights: Economics and Policy Analysis 
37. Daniel Dalohoun

The relationship between R\&D partnership formation, social embeddedness and innovative performance: a multilevel approach of social embeddedness

36. MügeOzman

Networks, Organizations and Knowledge

35. Bas Straathof

Product variety and economic growth: The counteracting effects of scale and idiosyncrasy

34. Wilfred Schoenmakers

Knowledge Flows between Multinational Companies: A Patent Data Analysis

33. MyriamCloodt

Mergers and Acquisitions (M\&As) in

High-Tech Industries: Measuring the

Post-M\&A Innovative Performance of Companies

32. Paola Criscuolo

R\&D Internationalisation and Knowledge Transfer. Impact on MNEs and their Home Countries

31. Maarten Verkerk

Trust and Power on the Shop Floor

30. Gottfried Leibbrandt

Adoption, harmonization and succession of network technologies across countries

29. Mark Sanders

Skill Biased Technical change - Its Origins, the Interaction with the Labour Market and Policy Implications

2003

28. Nadine Roijakkers Inter-firm cooperation in high-tech industries: a study of R\&D partnerships in pharmaceutical biotechnology

27. Viki Sonntag

Speed, Scale and Sustainability
26. Masaru Yarime

From End-of-Pipe Technology to Clean Technology

25. StéphaneMalo

The combinatorial Chemistry Revolution

- Sustaining a Superior Performance Position through Technological Learning

2002

24. AnneliesHogenbirk

Determinants of Inward Foreign Direct Investment: the Case of the Netherlands

2001

23. John Adeoti

Technology Investment in Pollution Control in Sub-Saharan Africa: The Case of the Nigerian Manufacturing Industry

22. Edward Huizenga

Innovation Management: How Frontrunners Stay Ahead. An Empirical Study on Key Success Factors in the ICT sector

2000

21. Machiel van Dijk

Technological Change and the Dynamics of Industries. Theoretical Issues and Empirical evidence from Dutch Manufacturing

1999

20. Jan Cobbenhagen

Managing Innovation at the Company Level: A Study on Non-Sector-Specific Success Factors

19. MarjoleinCaniëls

Regional Growth Differentials: The Impact of Locally Bounded Knowledge Spillovers

1998

18. Aldo Geuna

Resource allocation and knowledge production: Studies in the economics of university research 
17. Reinoudjoosten

Dynamics, Equilibria, and Values

16. Hugo Kruiniger

Investment, R\&D, and the Financing Decisions of the Firm

1995

15. Hans van Meijl

Endogenous Technological Change: The Case of Information Technology. Theoretical Considerations and Empirical Results

14. René Kemp

Environmental Policy and Technical Change. A Comparison of the Technological Impact of Policy Instruments

13. Rohini Acharya

The Impact of New Technologies on Economic Growth and Trade. A Case Study of Biotechnology

12. Geert Duysters

The Evolution of Complex Industrial Systems. The Dynamics of Major IT Sectors

11. MarjanGroen

Technology, Work and Organisation, A Study of the Nursing Process in Intensive Care Units

10. HuubMeijers

On the Diffusion of Technologies in a Vintage Framework; Theoretical Considerations and Empirical Results

9. Theon van Dijk

The Limits of Patent Protection. Essays on the Economics of Intellectual Property Rights
8. Hans Voordijk

NaarIntegraleLogistiek in Bedrijfsketens, Ontwikkelingen in de Bouw

1993

7. Paul Diederen

Technological Progress in Enterprises and Diffusion of Innovations.Theoretical Reflections and Empirical Evidence.

6. Ben Dankbaar

Economic Crisis and Institutional Change. The crisis of Fordism from the perspective of the automobile industry

5. Hanno Roberts

Accountability and Responsibility: The Influence of Organisation Design on Management Accounting

1992

\section{Bart Verspagen}

Uneven Growth Between Interdependent Economies. An Evolutionary View on Technology Gaps, Trade and Growth

3. Sjoerd Romme

A Self-organization Perspective on Strategy Formation 1989

2. John Spangenberg Economies of Scale, and Atmosphere in Research Organisations

\section{8}

1. John Hagedoorn

Evolutionary and heterodox innovation analysis: a study of industrial and technological development in process control and information technology 


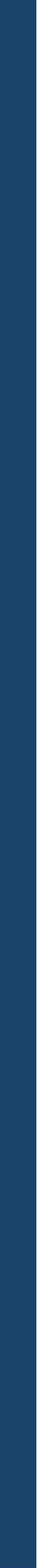

